\title{
Numerical simulation of inorganic Cs2AgBiBr6 as a lead-free perovskite using device simulation SCAPS-1D
}

\section{Aminreza Mohandes}

Shiraz University

Mahmood Moradi ( $\triangle$ mmoradi@shirazu.ac.ir)

Shiraz University https://orcid.org/0000-0001-5258-056X

Hamid Nadgaran

Shiraz University

\section{Research Article}

Keywords: Cs2AgBiBr6, Double perovskite solar cell, Lead-free perovskite, Conduction band offset (CBO), Valence band offset (VBO), SCAPS

Posted Date: April 15th, 2021

DOI: https://doi.org/10.21203/rs.3.rs-320895/v1

License: (c) (i) This work is licensed under a Creative Commons Attribution 4.0 International License. Read Full License 


\title{
Numerical simulation of inorganic $\mathrm{Cs}_{2} \mathrm{AgBiBr}_{6}$ as a lead-free perovskite using device simulation SCAPS-1D
}

\author{
Aminreza Mohandes. Mahmood Moradi. Hamid Nadgaran
}

\begin{abstract}
Double perovskite, $\mathrm{Cs}_{2} \mathrm{AgBiBr}_{6}$, is introduced as a lead-free perovskite solar cell. Device modeling of $\mathrm{Cs}_{2} \mathrm{AgBiBr}_{6}$ (DP) was accomplished to obtain the optimum parameters using the Solar Cell Capacitance Simulator (SCAPS). Two devices with two different hole transport layers ( $\mathrm{HTLS}$ ) were investigated, including $\mathrm{P}_{3} \mathrm{HT}$ and $\mathrm{Cu}_{2} \mathrm{O}$. For both devices with different HTLs, an optimal thicknesses of $1200 \mathrm{~nm}$ and defect densities of $1.0 \times 10^{14} \mathrm{~cm}^{-3}$ for DP layer were attained. For both HTLs, conduction band offset, $\mathrm{CBO}$, is $-0.21 \mathrm{eV}$ and valence band offset, $\mathrm{VBO}$, is $+0.16 \mathrm{eV}$. For shallow acceptor doping concentration of $\mathrm{P}_{3} \mathrm{HT}$ and $\mathrm{Cu}_{2} \mathrm{O}$, the values of $5.0 \times 10^{19}$ and $5.0 \times 10^{17} \mathrm{~cm}^{-3}$ were obtained, respectively. As far as the shallow donor density of electron transport layers (ETLs) is concerned, for both cases, the optimum value of $5.0 \times 10^{19} \mathrm{~cm}^{-3}$ were achieved. For capture cross section, $\sigma_{n, p}$, in absorber layer for both HTLs, the optimal value at $\sigma_{n, p}$ of $10^{-20} \mathrm{~cm}^{2}$ for $N_{t, D P}$ (defect density of DP) is $10^{16} \mathrm{~cm}^{-3}$, at $\sigma_{n, p}$ of $10^{-19} \mathrm{~cm}^{2}$ for $N_{t, D P}$ is $10^{15} \mathrm{~cm}^{-3}$, at $\sigma_{n, p}$ of $10^{-18} \mathrm{~cm}^{2}$ for $N_{t, D P}$ is $10^{14} \mathrm{~cm}^{-3}$, at $\sigma_{n, p}$ of $10^{-17} \mathrm{~cm}^{2}$ for $N_{t, D P}$ is $10^{13} \mathrm{~cm}^{-3}$, and at $\sigma_{n, p}$ of $10^{-16} \mathrm{~cm}^{2}$ for $N_{t, D P}$ is $10^{12} \mathrm{~cm}^{-3}$. For $\mathrm{P}_{3} \mathrm{HT}$ device, the interface defect density of $\mathrm{P}_{3} \mathrm{HT} / \mathrm{Cs}_{2} \mathrm{AgBiBr}_{6}$ is occurred at $1.0 \times 10^{14} \mathrm{~cm}^{-2}$, and for $\mathrm{Cs}_{2} \mathrm{AgBiBr}_{6} / \mathrm{SnO}_{2}$ is happened at $1.0 \times 10^{9} \mathrm{~cm}^{-2}$. For $\mathrm{Cu}_{2} \mathrm{O}$ device, the interface defect density of $\mathrm{Cu}_{2} \mathrm{O} / \mathrm{Cs}_{2} \mathrm{AgBiBr}_{6}$ is befallen at $1.0 \times 10^{13} \mathrm{~cm}^{-2}$, and for $\mathrm{Cs}_{2} \mathrm{AgBiBr}_{6} / \mathrm{SnO}_{2}$ is happened at $1.0 \times 10^{10} \mathrm{~cm}^{-2}$. As for radiative recombination, for $\mathrm{P}_{3} \mathrm{HT}$ device, the optimal value is happened at $2.3 \times 10^{-13} \mathrm{~cm}^{3} / \mathrm{s}$, however, for $\mathrm{Cu}_{2} \mathrm{O}$ device is occurred at $2.3 \times 10^{-12} \mathrm{~cm}^{3} / \mathrm{s}$. Finally, for $\mathrm{P}_{3} \mathrm{HT}$ device, a maximum power conversion efficiency, $\mathrm{PCE}$, of $11.69 \%$ (open-circuit voltage, $\mathrm{V}_{\mathrm{oc}}$, of $2.02 \mathrm{~V}$, short-circuit current density, $\mathrm{J}_{\mathrm{sc}}$, of $6.39 \mathrm{~mA} / \mathrm{cm}^{2}$, and fill-factor, $\mathrm{FF}$, of $\left.0.90(90 \%)\right)$ were achieved, and for $\mathrm{Cu}_{2} \mathrm{O}$ device, a PCE of $11.32 \%\left(\mathrm{~V}_{\text {oc }}\right.$ of 1.97 $\mathrm{V}, \mathrm{J}_{\mathrm{sc}}$ of $6.39 \mathrm{~mA} / \mathrm{cm}^{2}$, and FF of $\left.0.895(89.5 \%)\right)$ were attained. This is the highest efficiency for $\mathrm{Cs}_{2} \mathrm{AgBiBr}_{6} \mathrm{double}$ perovskite solar cell which was achieved till now. Finally, our results are providing towards fabricating a lead-free and inorganic solar cell.
\end{abstract}

Keywords $\mathrm{CS}_{2} \mathrm{AgBiBr}_{6}$. Double perovskite solar cell. Lead-free perovskite. Conduction band offset (CBO). Valence band offset (VBO). SCAPS

\footnotetext{
1 Mahmood Moradi

mmoradi@shirazu.ac.ir

Department of Physics, Shiraz University, College of Science, Shiraz 71946-84795, Iran
} 


\section{Introduction}

Perovskite solar cells (PSCs) have gained more than 25\% efficiency within a very short period (Usiobo et al. 2020). Although PSCs have some advantages such as indicating high charge carrier mobilities, high absorption coefficients, direct and tunable band gaps, long carrier diffusion lengths, and high performance (Zhang and Zhu 2020; Gu et al. 2020; Li and Zhang 2020), they endure from instability issue, mostly owing to perovskite material deterioration upon moisture and light exposure (He et al. 2020; Singh et al. 2020; Lee and Park 2020; Yang et al. 2020). Moreover, the stability of the PSCs are researching (Bouich et al. 2021; Mohseni et al. 2021). Despite some advantages, the presence of lead and the toxicity in these kind of cells is a major blockage to its commercialization (Xu et al. 2020). In order to overcome the existing shortcoming related to the presence of lead in the perovskite solar cell, the main competitor is to replace tin (Xu 2021; Poli et al. 2021; Liu et al. 2020; Jiang et al. 2020; Li et al. 2020) and germanium (Soto-Montero et al. 2020; Liu et al. 2020) belonging to the same lead group, therefore we expect the exhibition of similar properties. For lead-free perovskite solar cells, since tin has the same diameter as lead, the scientists are encouraged to replace tin with lead to form $\mathrm{ASnX}_{3}$ (Ogomi et al. 2014; Zuo et al. 2014; Noel et al. 2014; Liao et al. 2016; Xi et al. 2017; Shi et al. 2017). However, $\mathrm{Sn}^{2+}$ ion is unstable in these materials and easily oxidize to $\mathrm{Sn}^{4+}$ which results in degradation of photovoltaic performance.

The other way to develop the perovskite family for photovoltaic application is to replace $\mathrm{Pb}^{2+}$ ion with one monovalent $\mathrm{B}^{+}$and one trivalent $\mathrm{B}^{3+}$ ion, forming $\mathrm{A}_{2} \mathrm{~B}^{+} \mathrm{B}^{3+} \mathrm{X}_{6}$, double perovskite (DP) structure called elpasolite (Zhao et al. 2017). More than 300 diverse elpasolites have been synthesized till now (Giustino and Snaith 2016). Nevertheless, so far only three of them, including $\mathrm{Cs}_{2} \mathrm{AgBiBr}_{6}$ (Slavney et al. 2016), $\mathrm{Cs}_{2} \mathrm{AgBiCl}_{6}$ ( $\mathrm{McClure}$ et al. 2016) and $\left(\mathrm{CH}_{3} \mathrm{NH}_{3}\right)_{2} \mathrm{AgBiBr}_{6}$ (Wei et al. 2017) have been produced. The bandgap engineering of $\mathrm{Cs}_{2} \mathrm{AgBiBr}_{6}$ has been done by inducing defects and alloying of triple metals (Slavney et al. 2017; Du et al. 2017). Among the double perovskite family, $\mathrm{Cs}_{2} \mathrm{AgBiBr}_{6}$ is a suitable absorbing layer in solar cell devices, because it has high crystallinity, encouraging photovoltaic properties including long carrier recombination lifetime, good stability against air and moisture, low carrier effective masses and both thermal stability and fabricated in the ambient as compared to the perovskite structure, and long carrier diffusion length of around 700 nm (Yang et al. 2020; Longo et al. 2020; Burwig et al. 2020; Ghasemi et al. 2020; Zhang et al. 2020).

While the double perovskite solar cell is more stable as compared to perovskite cell, it has much lower inherent efficiency than that of perovskite cell (Wu et al. 2018). For instance, for the device of ITO/ $\mathrm{SnO}_{2} / \mathrm{Cs}_{2} \mathrm{AgBiBr}_{6} / \mathrm{P}_{3} \mathrm{HT} / \mathrm{Au}$, the efficiency was attained to be $1.44 \%$ experimentally (Wu et al. 2018).

Although $\mathrm{P}_{3} \mathrm{HT}$ (poly(3-hexylthiophene-2,5-diyl)) is a good candidate material for the realization of PSC industrialization, $\mathrm{P}_{3} \mathrm{HT}$ endures from some inherent drawbacks, such as elevated levels of occupied molecular orbital energy (HOMO) and narrow visible light absorption range $(<650 \mathrm{~nm})$, leads to low efficiency and low $V_{\text {oc }}$ (Kim et al. 2020; Chow et al. 2020). Lately, it has been reported that $\mathrm{Cu}_{2} \mathrm{O}$ (cuprous oxide) has emanated as a strong option for the HTL owing to its very high mobility, optimal direct bandgap and significantly inorganic, consequently it has low degradability characteristic (Mkhalid and Shawky 2021; Islam et al. 2020). Besides, 1.0 gr of $\mathrm{P}_{3} \mathrm{HT}$ is around 547 EURO depending on purity degrees, while $1.0 \mathrm{gr} \mathrm{Cu}_{2} \mathrm{O}$ is around 11.76 EURO depending on purity degrees (www.sigmaaldrich.com/germany.html). As far as price is concerned, it rises to the attention that $\mathrm{Cu}_{2} \mathrm{O}$ is the best example between two HTLs, in consequence of the lower cost.

Islam et al. 2020 used wxAMPS software to find the efficiency of $\mathrm{Cs}_{2} \mathrm{AgBiBr}_{6}$ double perovskite and as they mentioned in the conclusion of their report, they obtained the effiecency of 8.11 certainly. However, for the other double perovskite such as $\mathrm{Cs}_{2} \mathrm{TiBr}_{6}$, the efficiency in the experiment was attained to be $2.15 \%$ (Chen et al. 2018). After performing optimization, the efficiency is reached to $11.49 \%$, which means that efficiency is improved theoretically by 434.41\% (Ahmed et al. 2021).

In this work, the $\mathrm{Cs}_{2} \mathrm{AgBiBr}_{6}$ double perovskite is offered as a lead-free perovskite as an active layer in solar cell. Two devices with two different $\mathrm{HTLS}$ including $\mathrm{P}_{3} \mathrm{HT}$ and $\mathrm{Cu}_{2} \mathrm{O}$ are comperehensively surveyed in the simulation using SCAPS software and optimizing widely most of the parameters to get the highest efficiency.

\section{Methodology}

The Solar Cell Capacitance Simulator (SCAPS) is implemented in this research. The ver. 3.3.07 of this package established by University of Gent is used in our calculations (Burgelman et al. 2000). The SCAPS software is one dimensional simulation program that computes energy bands, concentrations, J-V characteristics, ac characteristics (C (Capacitance) and $G$ (Conductance) as functions of $V$ and $f$ ) and spectral response (QE) using the three basic semiconductor equations comprise of the continuity equations for hole and electron and Poisson's equation, as shown in Eq. (1)-(3) under the steady-state conditions, $\frac{d n_{p}}{d t}=\frac{d p_{n}}{d t}=0$.

$$
\frac{d n_{p}}{d t}=G_{n}-\frac{n_{p}-n_{p 0}}{\tau_{n}}+n_{p} \mu_{n} \frac{d \xi}{d x}+\mu_{n} \xi \frac{d n_{p}}{d x}+D_{n} \frac{d^{2} n_{p}}{d x^{2}}
$$




$$
\begin{aligned}
& \frac{d p_{n}}{d t}=G_{p}-\frac{p_{n}-p_{n_{0}}}{\tau_{p}}+p_{n} \mu_{p} \frac{d \xi}{d x}+\mu_{p} \xi \frac{d p_{n}}{d x}+D_{p} \frac{d^{2} p_{n}}{d x^{2}} \\
& \frac{d}{d x}\left(-\epsilon(x) \frac{d \psi}{d x}\right)=q\left[p(x)-n(x)+N_{D}^{+}(x)-N_{A}^{-}(x)+p_{t}(x)-n_{t}(x)\right]
\end{aligned}
$$

where $G_{n}, G_{p}$ indicates the generation rate of electrons and holes, $\mu_{\mathrm{n}}$ and $\mu_{\mathrm{p}}$ are electron and hole mobilities, $\xi$ is the electric field, $D$ is diffusion coefficient, $\tau$ is the life time of electrons and holes, $\epsilon$ is permittivity, $\psi$ is electrostatic potential, $q$ is electron charge, $p_{t}(x)$ and $n_{t}(x)$ are the concentrations of trapped holes and electrons, $N_{D}$ and $N_{A}$ are shallow donor and acceptor concentrations.

\section{Device structure and simulation parameters}

Figure 1 shows the schematic diagram of multilayer used in the double perovskite solar cell. The device contains of indium tin oxide (ITO)/electron transport layer $\left(\mathrm{SnO}_{2}\right)$ / absorber layer $\left(\mathrm{Cs}_{2} \mathrm{AgBiBr}_{6}\right) /$ hole transport layer $\left(\mathrm{P}_{3} \mathrm{HT}\right) / \mathrm{Au}$ (Wu et al. 2018). We used the following arrangement to perform the simulation.

In Table 1, the simulation parameters of all layers such as thickness, band gap energy $E_{g}$, electron affinity $\chi$, relative permittivity $\varepsilon_{r}$, effective density of states of conduction band $N_{C}$, effective density of states of valence band $N_{V}$, mobility of electron $\mu_{n}$, mobility of hole $\mu_{p}$, shallow donor density $N_{D}$, shallow acceptor density $N_{A}$ and defect density $\mathrm{N}_{\mathrm{t}}$ are presented.

Some other parameters and settings are given in the following. The thermal velocity of electron and hole is 1.0 $\times 10^{7} \mathrm{~cm} / \mathrm{s}$. The $\mathrm{N}_{\mathrm{ts}}$ suggests the defect density at the interface. The $\mathrm{N}_{\mathrm{ts}}$ quantities at $\mathrm{SnO}_{2} / \mathrm{Cs}_{2} \mathrm{AgBiBr}_{6}$ and $\mathrm{Cs}_{2} \mathrm{AgBiBr}_{6} / \mathrm{P}_{3} \mathrm{HT}$ interfaces are fixed to $2.3 \times 10^{10} \mathrm{~cm}^{-2}$ to achieve the recombination velocities of $0.74 \mathrm{~cm} / \mathrm{s}$ at both interfaces. The defect energy level is selected at the center of band gap and defect type is neutral. The energetic distribution is Gaussian and its characteristic energy is $0.1 \mathrm{eV} . R_{\mathrm{S}}$ is the series resistance with the unit of $\Omega . \mathrm{cm}^{2}$. The $\mathrm{N}_{\mathrm{t}}$ of the $\mathrm{Cs}_{2} \mathrm{AgBiBr}_{6}$, shown in Table 1, is fixed to $3.678 \times 10^{16} \mathrm{~cm}^{-3}$, as stated by the following formula:

$$
N_{t}=\frac{2 \varepsilon_{0} \varepsilon V_{T F L}}{q L^{2}}
$$

where $\varepsilon_{0}$ is the vacuum permittivity and $\varepsilon$ is the dielectric permittivity of $\mathrm{Cs}_{2} \mathrm{AgBiBr}_{6}$ film. $L$ is the thickness of the $\mathrm{Cs}_{2} \mathrm{AgBiBr}_{6}$ film and $q$ is the elementary charge. The $V_{\text {TFL }}$ (the trap-filled limit voltage) of the $\mathrm{Cs}_{2} \mathrm{AgBiBr}_{6}$ is $1.29 \mathrm{~V}$, according to the Supporting Information of reference (Wu et al. 2018). For this compound, the carrier lifetime is 843.6 $n s, L_{n}$ of $5.1 \mu \mathrm{m}$ and $L_{p}$ of $1 \mu \mathrm{m}$ (Wu et al. 2018). Moreover, the optical reflection of front contact, see Fig. 1, is assumed to be $40 \%$. The obtained capture cross section of electron and hole is $3.22 \times 10^{-18} \mathrm{~cm}^{2}$, according to the following formula:

$$
\sigma_{n, p}=\frac{1}{N_{t} V_{t h} \tau_{n, p}}
$$

Where $\sigma_{n, p}$ is capture cross section of electron and hole, $N_{t}$ is defect density of $\mathrm{Cs}_{2} \mathrm{AgBiBR}_{6}$ layer, $V_{t h}$ is thermal velocity of electron and hole and $\tau_{n, p}$ is the carrier lifetime of electron and hole. Right and left contact work function are 4.8 $\mathrm{eV}$ (ITO) and $5.1 \mathrm{eV}(\mathrm{Au})$, respectively. Pre-factor $A_{\alpha}$ for $\mathrm{Cs}_{2} \mathrm{AgBiBr}_{6}$ is set to $2.62 \times 10^{4} \mathrm{~cm}^{-1} \mathrm{eV}^{-1 / 2}$ to acquire absorption coefficient, $\alpha$, as computed by $\alpha=A_{\alpha}\left(h v-E_{g}\right)^{1 / 2}$, where the $h v$ is the photon energy. All simulations are accompanied under AM $1.5 \mathrm{G}$ illumination and temperature 300 Kelvin. 


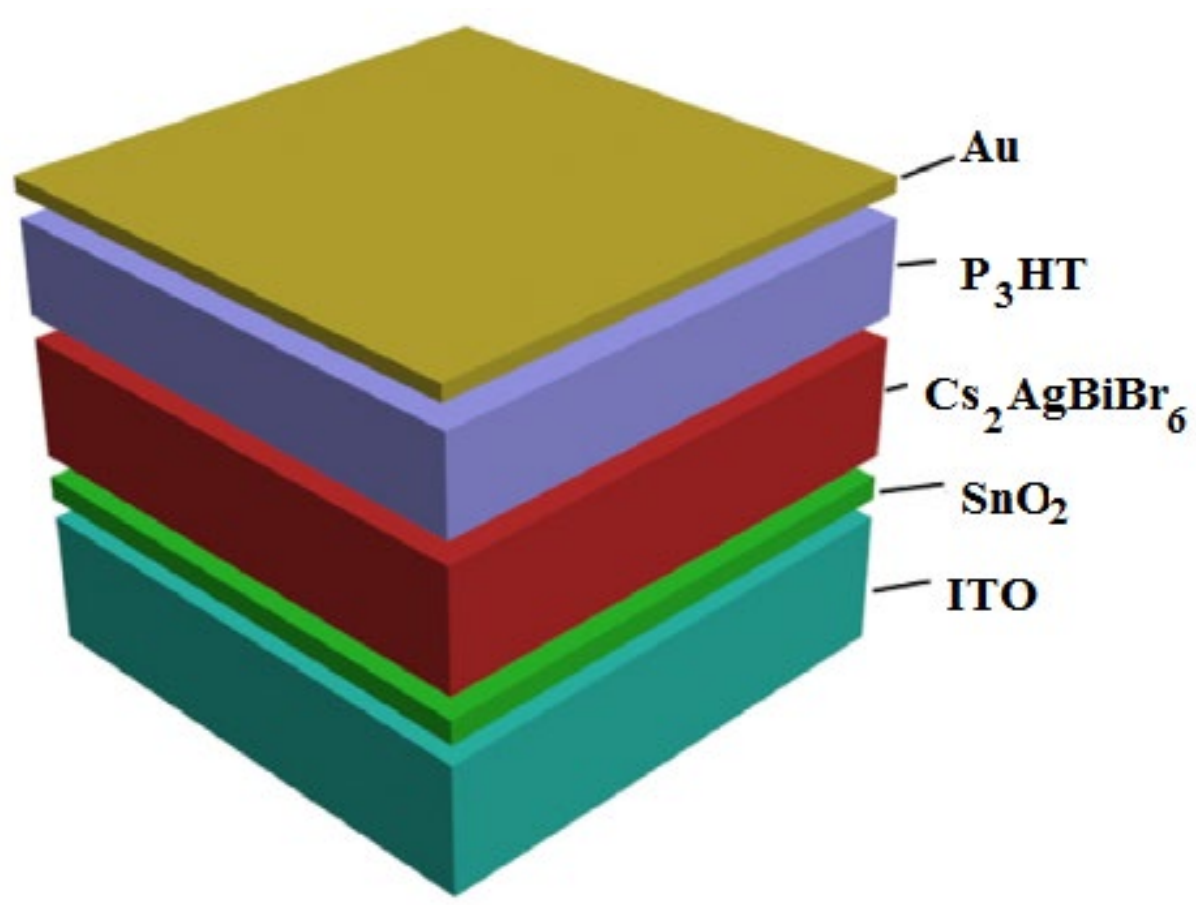

Fig. 1 Device multilayer structure, ITO/SnO${ }_{2} / \mathrm{Cs}_{2} \mathrm{AgBiBr}_{6} / \mathrm{P}_{3} \mathrm{HT} / \mathrm{Au}$, used in solar cells

The material parameters for the simulation are carefully selected from reported works (Wu et al. 2018; Ganvir 2016; Xu et al. 2019; Zhao et al. 2019; Minemoto et al. 2019; Islam et al. 2020; Coulibaly et al. 2019; Minbashi et al. 2018), as summarized in Table 1.

Table 1 Basic parameters for simulation of $\mathrm{Cs}_{2} \mathrm{AgBiBr}_{6}$ solar cells

\begin{tabular}{|c|c|c|c|c|c|}
\hline Parameters & ITO & $\mathrm{SnO}_{2}$ & $\mathrm{Cs}_{2} \mathrm{AgBiBr}_{6}$ & $\mathrm{P}_{3} \mathrm{HT}$ & $\mathrm{Cu}_{2} \mathrm{O}$ \\
\hline Thickness $(n \mathrm{~m})$ & 200 & 50 & 150 & 100 & 100 \\
\hline $\mathrm{N}_{\mathrm{D}}\left(\mathrm{cm}^{-3}\right)$ & $1.0 \times 10^{20}$ & $2.0 \times 10^{19}$ & $1.0 \times 10^{19}$ & 0.0 & 0.0 \\
\hline $\mathrm{N}_{\mathrm{A}}\left(\mathrm{cm}^{-3}\right)$ & 0.0 & 0.0 & $1.0 \times 10^{19}$ & $2.0 \times 10^{18}$ & $2.0 \times 10^{18}$ \\
\hline$\varepsilon_{\mathrm{r}}$ & 8.9 & 9.0 & 5.8 & 3.0 & 7.1 \\
\hline$\chi(\mathrm{ev})$ & 4.8 & 4.09 & 4.19 & 3.20 & 3.20 \\
\hline $\mathrm{E}_{\mathrm{g}}(\mathrm{ev})$ & 3.65 & 4.04 & 2.05 & 2.0 & 2.17 \\
\hline$\mu_{n}\left(\mathrm{~cm}^{2} V^{-1} \mathrm{~s}^{-1}\right)$ & 10.0 & 240 & 11.81 & $1.0 \times 10^{-4}$ & 200 \\
\hline$\mu_{p}\left(c m^{2} V^{-1} s^{-1}\right)$ & 10.0 & 25.0 & 0.49 & $1.0 \times 10^{-4}$ & 80 \\
\hline $\mathrm{N}_{\mathrm{c}}\left(\mathrm{cm}^{-3}\right)$ & $5.2 \times 10^{18}$ & $2.2 \times 10^{18}$ & $1.0 \times 10^{16}$ & $2.5 \times 10^{18}$ & $2.02 \times 10^{17}$ \\
\hline $\mathrm{N}_{\mathrm{v}}\left(\mathrm{cm}^{-3}\right)$ & $1.0 \times 10^{18}$ & $1.8 \times 10^{19}$ & $1.0 \times 10^{16}$ & $1.8 \times 10^{19}$ & $1.0 \times 10^{19}$ \\
\hline $\mathrm{N}_{\mathrm{t}}\left(\mathrm{cm}^{-3}\right)$ & $1.0 \times 10^{15}$ & $1.0 \times 10^{15}$ & $3.678 \times 10^{16}$ & $1.0 \times 10^{14}$ & $1.0 \times 10^{14}$ \\
\hline Radiative & $2.3 \times 10^{-9}$ & $2.3 \times 10^{-9}$ & $2.3 \times 10^{-9}$ & $2.3 \times 10^{-9}$ & $2.3 \times 10^{-9}$ \\
\hline
\end{tabular}

Recombination $\left(\mathrm{cm}^{3} /\right.$

\section{Results and discussion}

Figure 2a presents the current density-voltage (J-V) curves computed for ITO/SnO $/ \mathrm{Cs}_{2} \mathrm{AgBiBr}{ }_{6} / \mathrm{P}_{3} \mathrm{HT} / \mathrm{Au}$ cell by using the factors given in Tables 1 and 2 and comparing with the experiment (Wu et al. 2018). As Fig. 2b shows, the computed external quantum efficiency, EQE, is commenced from zero at $330 \mathrm{~nm}$ and achieved quickly to the apex of 
$23.60 \%$ at $340 \mathrm{~nm}$ and then decreased to zero at $610 \mathrm{~nm}$. The simulation and experimental results are compared in Table 3.

Table 2 Defect density at interfaces

\begin{tabular}{lcc}
\hline Interface defect density & ETL/absorber & absorber/HTL \\
\hline Defect type & Neutral & Neutral \\
Capture cross section electron $\left(\mathrm{cm}^{2}\right)$ & $3.22 \times 10^{-18}$ & $3.22 \times 10^{-18}$ \\
Capture cross section hole $\left(\mathrm{cm}^{2}\right)$ & $3.22 \times 10^{-18}$ & $3.22 \times 10^{-18}$ \\
Energy distribution & single & Single \\
Reference for defect energy level $\mathrm{E}_{\mathrm{t}}$ & Above the highest $E_{V}$ & Above the highest $E_{V}$ \\
Energy with respect to Reference $(\mathrm{eV})$ & 1.30 & 1.30 \\
Total density $\left(\mathrm{cm}^{-2}\right)$ & $2.3 \times 10^{10}$ & $2.3 \times 10^{10}$ \\
\hline
\end{tabular}

(a)
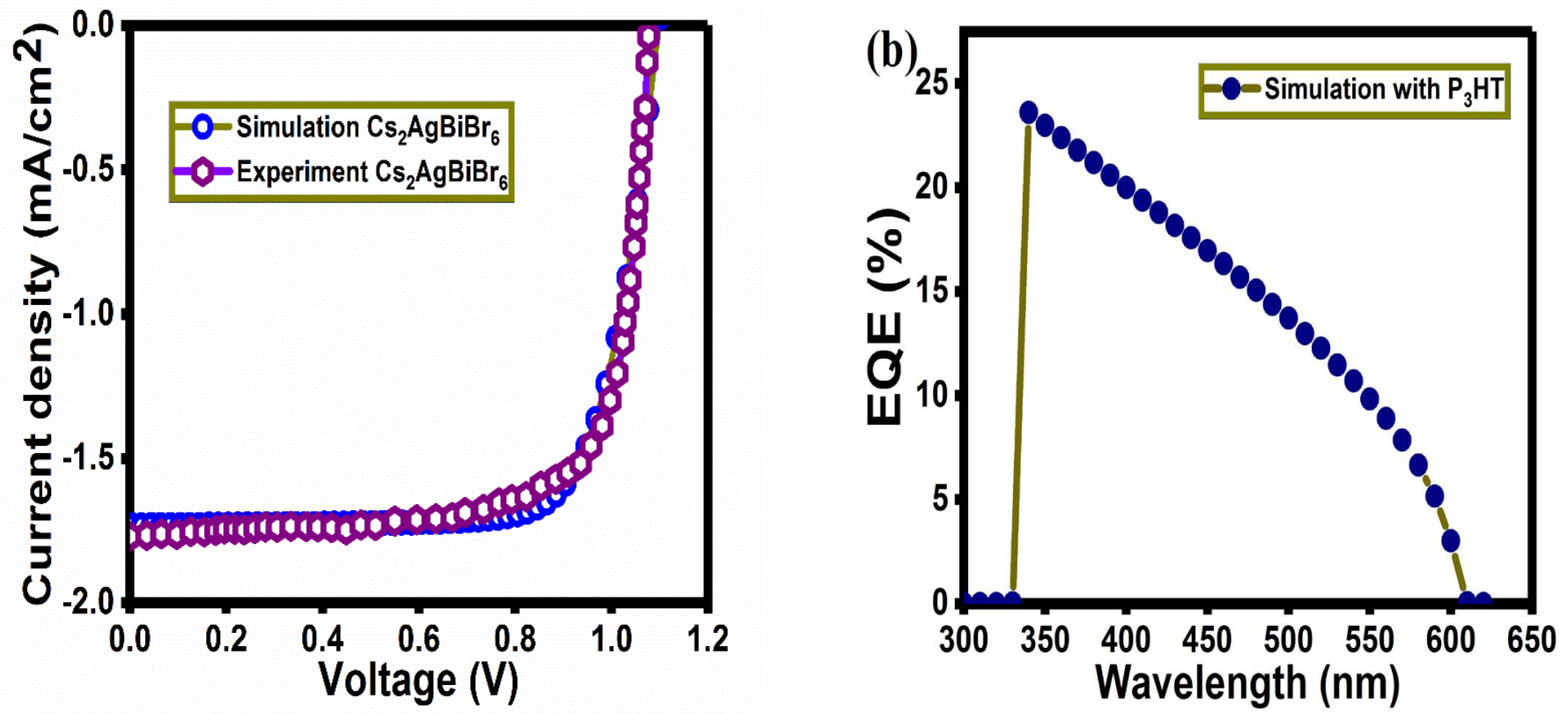

Fig. 2 a Comparison of our simulation and experimental results of current density-voltage curves. $\mathbf{b}$ Calculated external quantum efficiency of the double perovskite solar cell, for ITO/SnO $/ \mathrm{SS}_{2} \mathrm{AgBiBr}_{6} / \mathrm{P}_{3} \mathrm{HT} / \mathrm{Au}$ cell (Wu et al. 2018)

Table 3 Comparison of our simulation and experimental results of current density-voltage curves, for ITO $/ \mathrm{SnO}_{2} / \mathrm{Cs}_{2} \mathrm{AgBiBr}_{6} / \mathrm{P}_{3} \mathrm{HT} / \mathrm{Au}$ cell (Wu et al. 2018)

\begin{tabular}{cccccc}
\hline $\mathrm{Cs}_{2} \mathrm{AgBiBr}_{6}$ & $V_{o c}(V)$ & $J_{s c}\left(\frac{m A}{c m^{2}}\right)$ & FF & PCE (\%) & $R_{S}\left(\Omega . \mathrm{cm}^{2}\right)$ \\
\hline Simulation & 1.09 & 1.73 & 0.76 & 1.44 & 9.25 \\
Experiment & 1.04 & 1.78 & 0.78 & 1.44 & \\
\hline
\end{tabular}

In the next step, we are employing the other $\mathrm{HTL}$ such as $\mathrm{Cu}_{2} \mathrm{O}$. According to the data given in Tables 1 and 2, the current density-voltage curve and external quantum efficiency with $\mathrm{Cu}_{2} \mathrm{O}$ layer are plotted in Figs. $3 a$ and $3 b$, respectively. For ITO/SnO $2 / \mathrm{Cs}_{2} \mathrm{AgBiBr}_{6} / \mathrm{Cu}_{2} \mathrm{O} / \mathrm{Au}$ cell, the performance parameters are $\mathrm{V}_{\text {oc }}$ of $1.17 \mathrm{~V}, \mathrm{~J}_{\mathrm{sc}}$ of $3.42 \mathrm{~mA} / \mathrm{cm}^{2}$, FF of 0.78 and PCE of $3.13 \%$. As shown in Fig. $3 \mathrm{~b}$, the computed external quantum efficiency is started at $330 \mathrm{~nm}$ and reached swiftly to the apex of $44.12 \%$ at $340 \mathrm{~nm}$ and then decreased to zero at $610 \mathrm{~nm}$. 

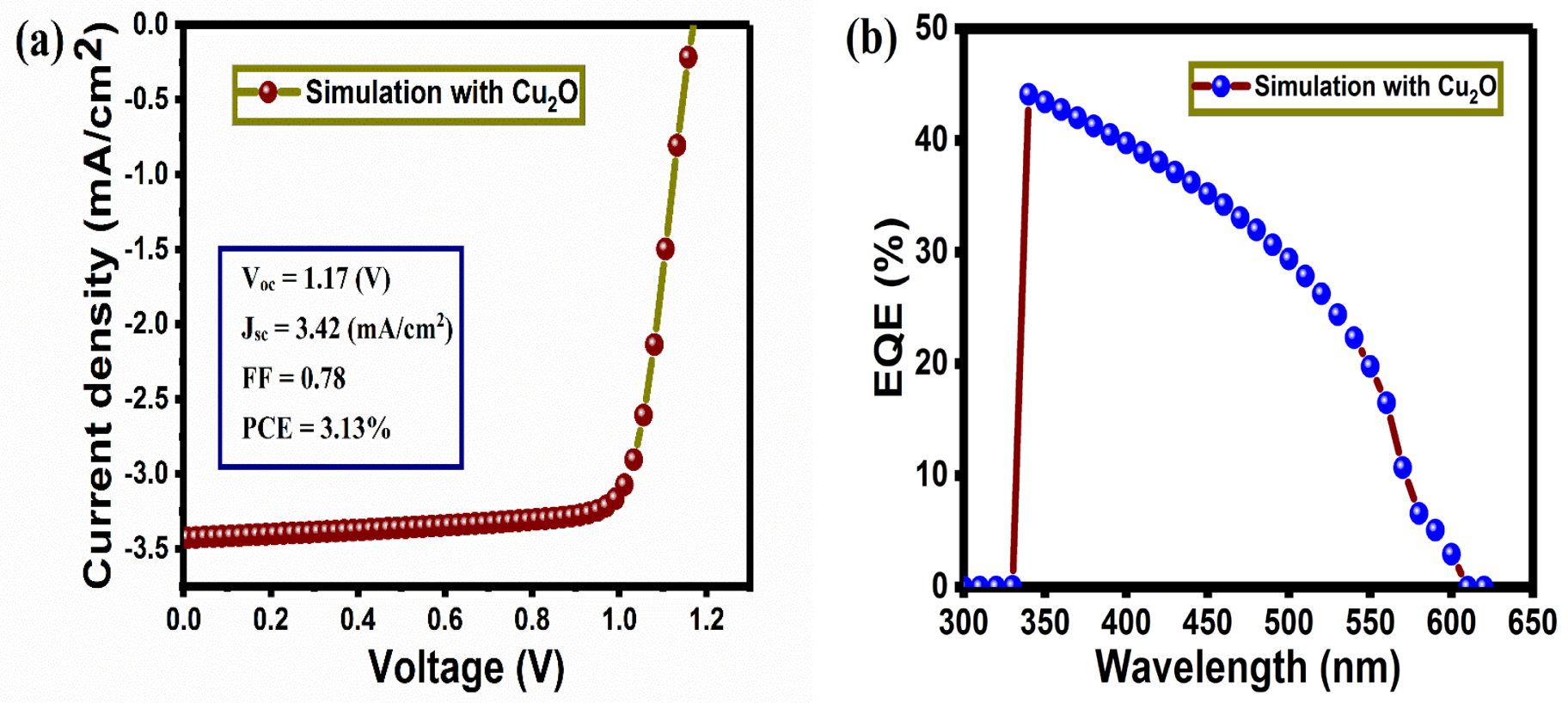

Fig. 3 a The current density-voltage curve, and $\mathbf{b}$ the computed external quantum efficiency, for ITO/SnO $/ \mathrm{Cs}_{2} \mathrm{AgBiBr}_{6} / \mathrm{Cu}_{2} \mathrm{O} / \mathrm{Au}$ cell

The performance parameters for two different HTLs are shown in Table 4, before optimizing parameters.

Table 4 Performance parameters attained for two different HTLs using SCAPS simulation

\begin{tabular}{cccccc}
\hline $\mathrm{HTL}$ & $\mathrm{V}_{\mathrm{oc}}(\mathrm{V})$ & $\mathrm{J}_{\mathrm{sc}}\left(\mathrm{mA} / \mathrm{cm}^{2}\right)$ & $\mathrm{FF}$ & $\mathrm{PCE}(\%)$ & $R_{s}\left(\Omega . \mathrm{cm}^{2}\right)$ \\
\hline $\mathrm{P}_{3} \mathrm{HT}$ & 1.09 & 1.73 & 0.76 & 1.44 & 9.25 \\
$\mathrm{Cu}_{2} \mathrm{O}$ & 1.17 & 3.42 & 0.78 & 3.13 & 9.25 \\
\hline
\end{tabular}

To get the required efficiency, we used the obtained optimal value of each quantity. Nevertheless, in this research, the improvements made in the efficiency have been explicated in the following sub-sections for ITO/SnO $2 / \mathrm{Cs}_{2} \mathrm{AgBiBr}_{6} / \mathrm{P}_{3} \mathrm{HT} / \mathrm{Au}$ cell.

\subsection{Effect of the double perovskite (absorber layer) thicknesses}

The effect of absorber layer thickness on the parameters of the double perovskite solar cell was calculated. The thickness of the double perovskite layer was altered from 100 to $2500 \mathrm{~nm}$, the attained parameters as a function of thickness are revealed in Fig. 4.

Figure $4 a$ exhibits the current density-voltage curves for different thicknesses of absorber layer changing from 100 to $2500 \mathrm{~nm}$. As a consequence of increasing the thickness of the absorbing layer, photons with longer wavelengths were also absorbed. This effect is associated with the enhancement of the collection of photogenerated carriers. According to Eq. (6), $\mathrm{V}_{\mathrm{oc}}$ is function of both $\mathrm{J}_{\mathrm{sc}}$ and the saturation current density of the device, $\mathrm{J}_{0}$, which is also influenced by the thickness of the absorber layer:

$$
V_{o c}=\frac{k T}{q} \ln \left(\frac{J_{s c}}{J_{0}}+1\right)
$$

Figures $4 \mathrm{~b}$ represents the performance parameters of $\mathrm{V}_{\mathrm{oc}}, \mathrm{J}_{\mathrm{sc}}$, FF and efficiency of the device as a function of thicknesses of absorber layer altering from 100 to $2500 \mathrm{~nm}$. According to Fig. 4b, the efficiency was started from $1.05 \%$ at $100 \mathrm{~nm}$ and then amended to the amount of $3.65 \%$ at $1200 \mathrm{~nm}$ and decreased to $2.92 \%$ at $2500 \mathrm{~nm}$, see Supporting Information of (Dang et. al 2020; Longo et. al. 2020) and (Keshavarz et al. 2020; Zhang et al. 2020). The FF, J $\mathrm{J}_{\mathrm{sc}}$, and $\mathrm{V}_{\mathrm{oc}}$ are also presented in Fig. $4 \mathrm{~b}$. Figure $4 \mathrm{c}$ exhibits the external quantum efficiency of $\mathrm{Cs}_{2} \mathrm{AgBiBr}_{6}$ device for different 
thicknesses altering in the same range. Therefore, the optimized parameter for this section is $1200 \mathrm{~nm}$. The $\mathrm{V}_{\text {oc }}$ of 1.08 $\mathrm{V}, \mathrm{J}_{\mathrm{sc}}$ of $6.33 \mathrm{~mA} / \mathrm{cm}^{2}, \mathrm{FF}$ of 0.53 and efficiency of $3.65 \%$ are attained.
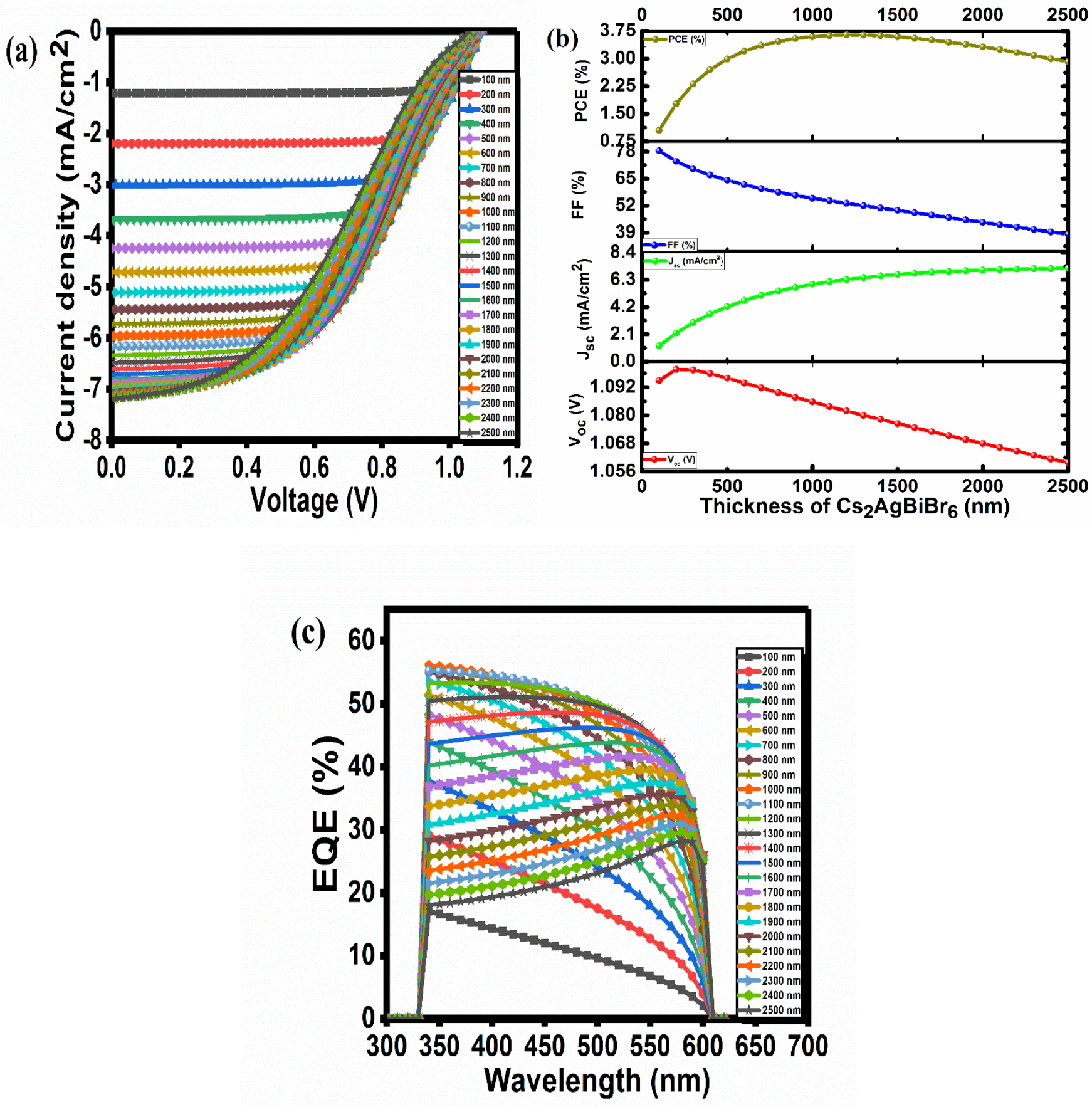

Fig. 4 a Current density-voltage curves for different thicknesses of $\mathrm{CS}_{2} \mathrm{AgBiBr}_{6}$. $\mathbf{b}$ The performance parameters of $\mathrm{V}_{\mathrm{oc}}, \mathrm{J}_{\mathrm{sc}}$, FF and efficiency of the device as a function of $\mathrm{Cs}_{2} \mathrm{AgBiBr}_{6}$ thicknesses. $\mathbf{c}$ The external quantum efficiency for various thicknesses of $\mathrm{Cs}_{2} \mathrm{AgBiBr}_{6}$ 


\subsection{Effect of defect densities, $\mathrm{N}_{\mathrm{t}}$, of $\mathrm{Cs}_{2} \mathrm{AgBiBr}_{6}$}

For supplementary enhancement in performance, defect density is another serious parameter which should be disputed. Defect density in $\mathrm{Cs}_{2} \mathrm{AgBiBr}_{6}$ are mostly point defects including Vacancy, Interstitial, and Antisite. We do not specifically report each of these defects (Islam et al. 2020). The performance of double perovskite solar cell is noticeably reformed by the morphology and quality of absorber layer film. As the quality of film is not ideal, the defect density improved and the recombination rate of the carriers enlarged in the absorbing layer, thus it disturbs the performance of the solar cell (Zhu et al. 2020; Li et al. 2019; Tan et al. 2020).

Figure 5 a demonstrates the current density-voltage curves for numerous defect density $\left(\mathrm{N}_{\mathrm{t}}\right)$ of $\mathrm{Cs}_{2} \mathrm{AgBiBr}_{6}$, changing from $10^{12}$ to $10^{17} \mathrm{~cm}^{-3}$. Figure $5 \mathrm{~b}$ indicates the performance parameters of $\mathrm{V}_{\mathrm{oc}}, \mathrm{J}_{\mathrm{sc}}, \mathrm{FF}$ and efficiency against defect density $\left(\mathrm{N}_{\mathrm{t}}\right)$ of device varying from $10^{12}$ to $10^{17} \mathrm{~cm}^{-3}$. As shown in Fig. $5 \mathrm{~b}$, the efficiency of device was initiated from $4.06 \%$ at $10^{12}, 10^{13}$ and $10^{14} \mathrm{~cm}^{-3}$ and reduced to $4.04 \%$ at $10^{15} \mathrm{~cm}^{-3}, 3.93 \%$ at $10^{16} \mathrm{~cm}^{-3}$, and $3.27 \%$ at $10^{17} \mathrm{~cm}^{-3}$. The FF, $\mathrm{J}_{\mathrm{sc}}$ and $\mathrm{V}_{\mathrm{oc}}$ are also plotted in Fig. 5b. As Fig. 5b suggests, the optimized value of these parameters can be acquired at defect density of $10^{14} \mathrm{~cm}^{-3}$. It is appeared that the high crystallinity of the double perovskite result in the minimum of defect density thereby dwindling charge recombination and thus higher efficiency are gained (Zhu et al. 2020; Li et al. 2019; Tan et al. 2020). The $\mathrm{V}_{\mathrm{oc}}$ of $1.09 \mathrm{~V}, \mathrm{~J}_{\mathrm{sc}}$ of $6.35 \mathrm{~mA} / \mathrm{cm}^{2}$, the FF of 0.58 and efficiency of $4.06 \%$ are gained.
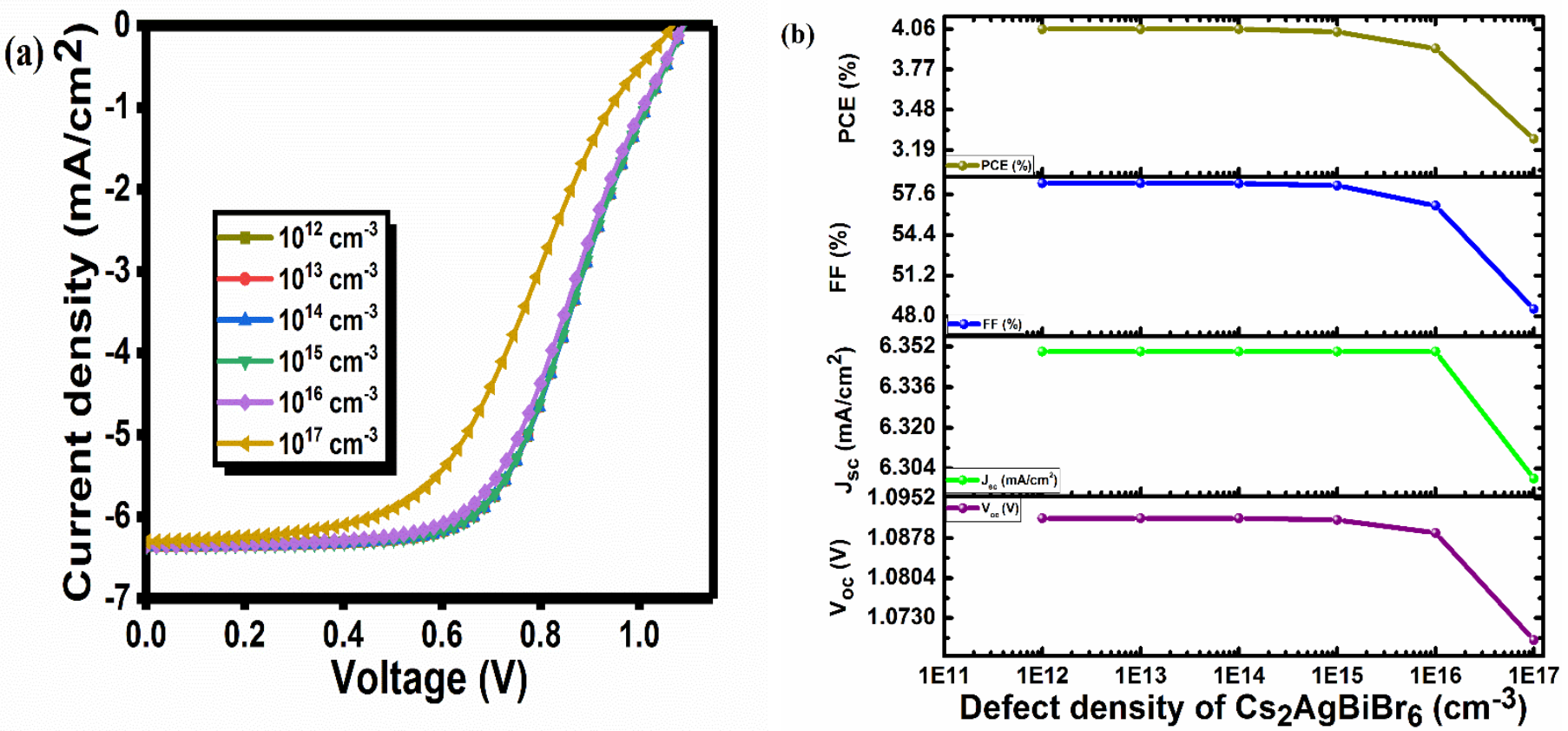

Fig. 5 a The current density- voltage curves for various defect density $\left(\mathrm{N}_{\mathrm{t}}\right)$ of device of $\mathrm{Cs}_{2} \mathrm{AgBiBr}_{6}$ changing from $10^{12}$ to $10^{17} \mathrm{~cm}^{-3}$. b The performance parameters of $\mathrm{V}_{\mathrm{oc}}, \mathrm{J}_{\mathrm{sc}}, \mathrm{FF}$, and efficiency against defect density $\left(\mathrm{N}_{\mathrm{t}}\right)$ of device varying from $10^{12}$ to $10^{17} \mathrm{~cm}^{-3}$

\subsection{Effect of the valence band offset at the HTL side}

The serious factor between $\mathrm{Cs}_{2} \mathrm{AgBiBr}_{6}$ and $\mathrm{P}_{3} \mathrm{HT}$ layers is band offset which controls the carrier recombination at the interface and it measures $\mathrm{V}_{\mathrm{oc}}$. By changing the band gaps of $\mathrm{P}_{3} \mathrm{HT}(1.5-3.2 \mathrm{eV})$, the band offset can be attuned, according to Table 1 and the following formula:

$$
V B O=\left(\chi_{H T L}+E_{g, H T L}\right)-\left(\chi_{D P}+E_{g, D P}\right)
$$

Where $\chi_{D P}$ and $\chi_{H T L}$ are the affinity, $E_{g, D P}$ and $E_{g, H T L}$ are the band gap of $\mathrm{Cs}_{2} \mathrm{AgBiBr}_{6}$ and $\mathrm{P}_{3} \mathrm{HT}$, respectively. VBO is enhanced from -1.54 to $+0.16 \mathrm{eV}$. Figure $6 \mathrm{a}$ exhibits the current density-voltage curves for various band gaps of $\mathrm{P}_{3} \mathrm{HT}$ changing from 1.5 to $3.2 \mathrm{eV}$. Figure $6 \mathrm{~b}$ displays the energy band diagrams for the band gaps of $\mathrm{P}_{3} \mathrm{HT}$ varying from 1.5 to $3.2 \mathrm{eV}$. As indicated by Fig. 6, the optimal value for VBO is happened at $+0.16 \mathrm{eV}$ (the band gap of $\mathrm{P}_{3} \mathrm{HT}$ is $3.2 \mathrm{eV}$ ). Since VBO is positive, the spike is established. Meanwhile, the formed spike is lower than $0.2 \mathrm{eV}$, the hole can move 
to $\mathrm{P}_{3} \mathrm{HT}$ (Minemoto and Murata 2015). The $\mathrm{V}_{\mathrm{oc}}$ of $1.87 \mathrm{~V}, \mathrm{~J}_{\mathrm{sc}}$ of $6.38 \mathrm{~mA} / \mathrm{cm}^{2}$, FF of 0.83 and efficiency of $10.0 \%$ are obtained.

(a)

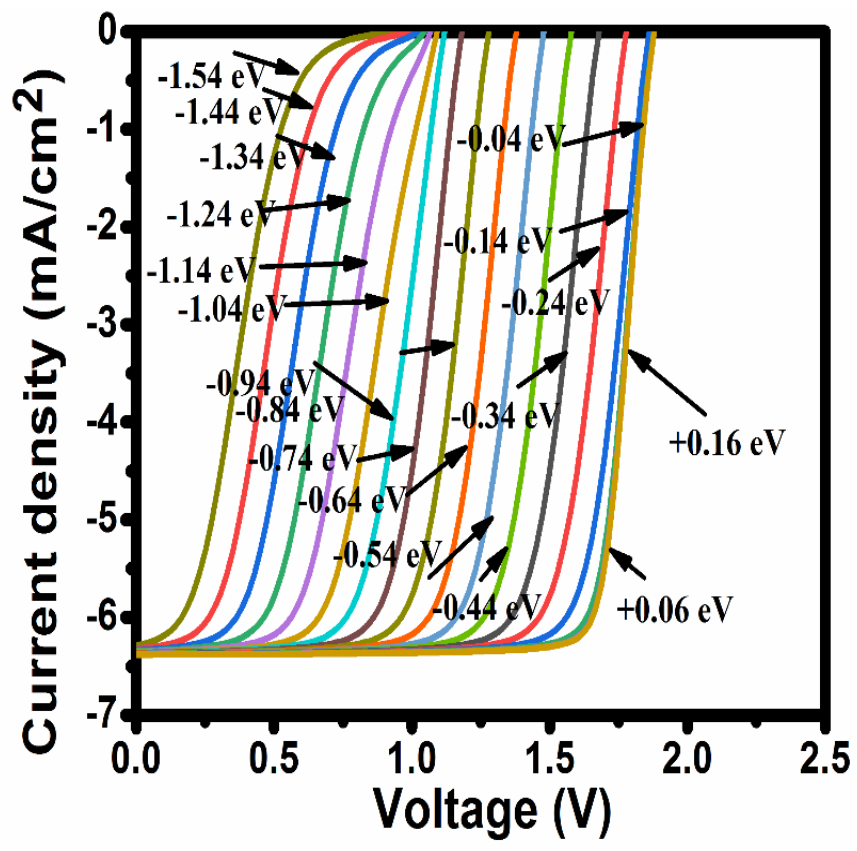

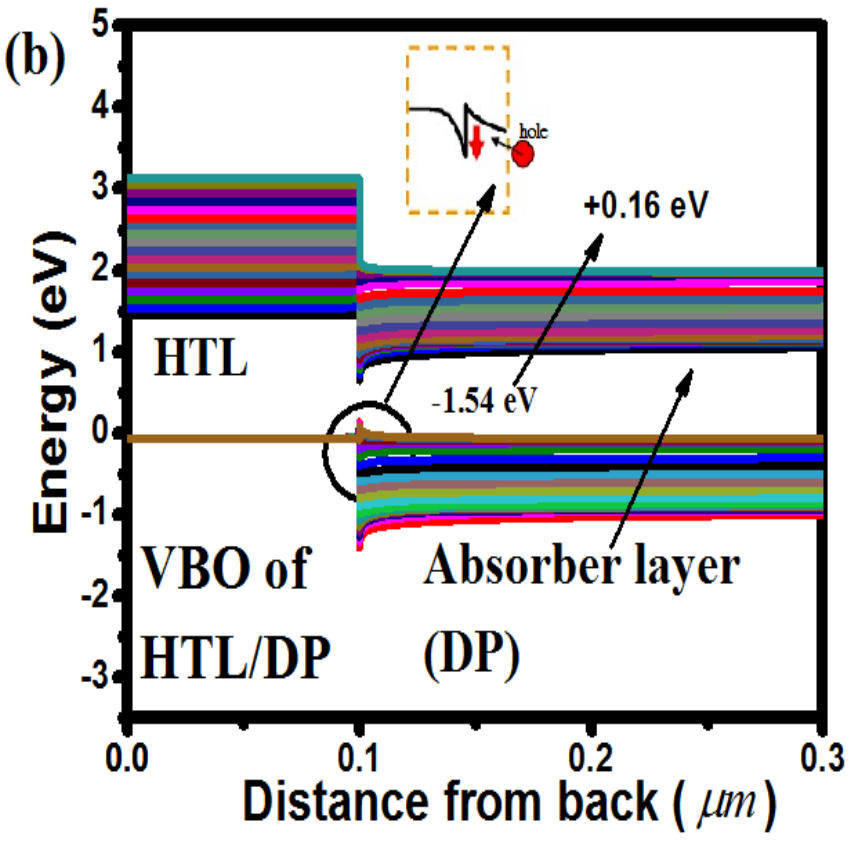

Fig. 6 a The current density-voltage curves for $\mathrm{VBO}$ of $\mathrm{P}_{3} \mathrm{HT} / \mathrm{Cs}_{2} \mathrm{AgBiBr}_{6}$ changing from -1.54 to $+0.16 \mathrm{eV}$. $\mathbf{b}$ The energy band diagrams for $\mathrm{VBO}$ of $\mathrm{P}_{3} \mathrm{HT}$ $/ \mathrm{Cs}_{2} \mathrm{AgBiBr}_{6}$ varying from -1.54 to $+0.16 \mathrm{eV}$

\subsection{Effect of the conduction band offset at the ETL side}

The earnest factor between $\mathrm{SnO}_{2}$ and $\mathrm{Cs}_{2} \mathrm{AgBiBr}_{6}$ layers is band offset which controls the carrier recombination at the interface and it evaluates $\mathrm{V}_{\mathrm{oc}}$. By altering the affinity of $\mathrm{SnO}_{2}$ in the range of 4.0 to $4.5 \mathrm{eV}$, the band offset can be adjusted. According to Table 1 and the following formula:

$$
C B O=\chi_{D P}-\chi_{E T L}
$$

Where $\chi_{D P}$ and $\chi_{E T L}$ are the affinity of $\mathrm{CS}_{2} \mathrm{AgBiBr}_{6}$ and $\mathrm{SnO}_{2}$, respectively. The obtained $\mathrm{CBO}$ is changed from +0.19 to $-0.31 \mathrm{eV}$. Figure $7 \mathrm{a}$ exhibits the current density-voltage curves for the $\mathrm{CBO}$ of $\mathrm{Cs}_{2} \mathrm{AgBiBr}_{6} / \mathrm{SnO}_{2}$ changing from +0.19 to $-0.31 \mathrm{eV}$, also Fig. $7 \mathrm{~b}$ displays the energy band diagrams. As indicated by these figures, the optimal value for CBO is occurred at $-0.21 \mathrm{eV}$ (affinity of $\mathrm{SnO}_{2}$ is $4.4 \mathrm{eV}$ ). The $\mathrm{CBO}$ is negative which means that the cliff is formed, the electron can simply drift to $\mathrm{SnO}_{2}$ (Minemoto and Murata 2015). The $\mathrm{V}_{\text {oc }}$ of $1.87 \mathrm{~V}, \mathrm{~J}_{\mathrm{sc}}$ of $6.39 \mathrm{~mA} / \mathrm{cm}^{2}, \mathrm{FF}$ of 0.88 and efficiency of $10.57 \%$ are achieved. 

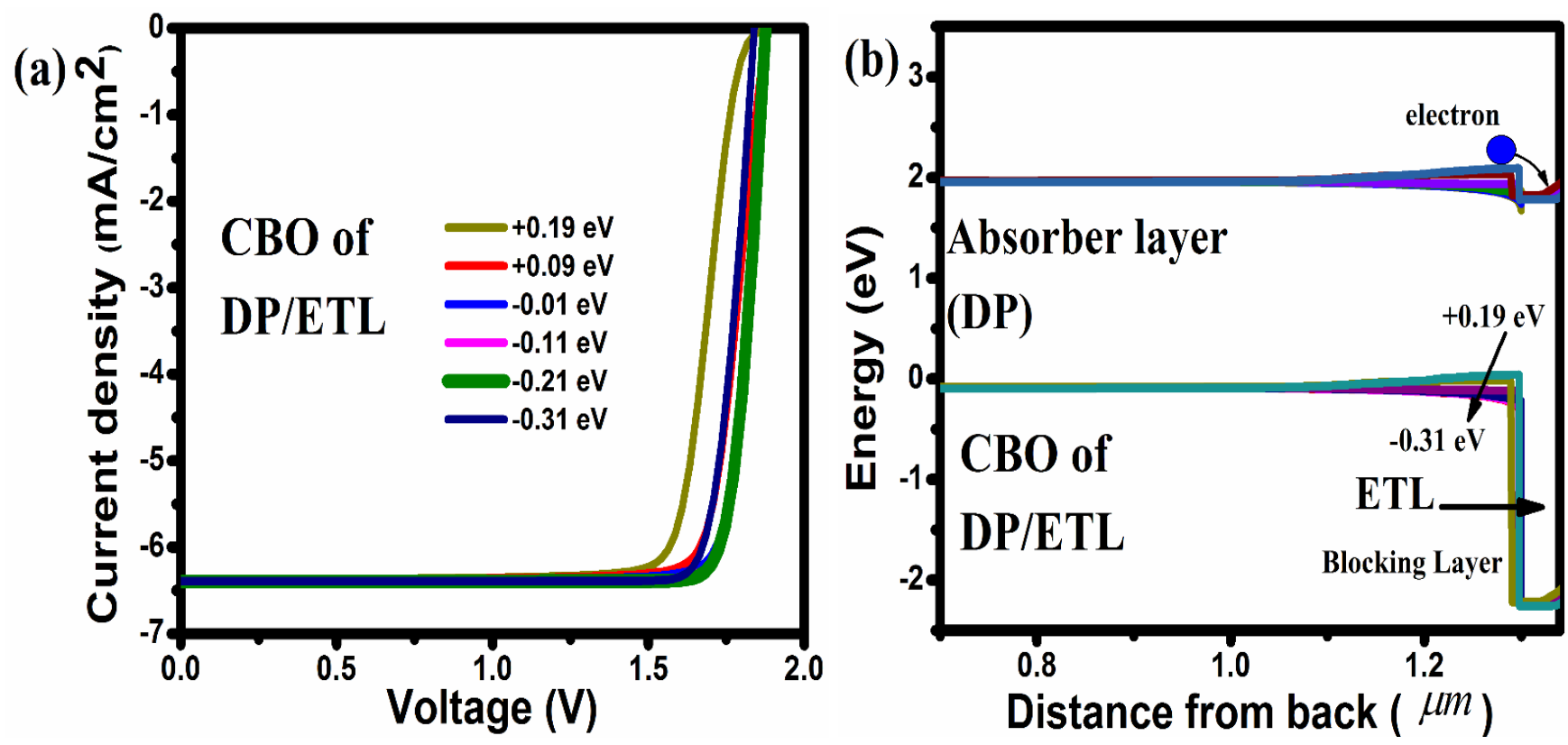

Fig. 7 a The current density-voltage curves for $\mathrm{CBO}$ of $\mathrm{Cs}_{2} \mathrm{AgBiBr}_{6} / \mathrm{SnO}_{2}$ changing from +0.19 to $-0.31 \mathrm{eV}$. $\mathbf{b}$ The energy band diagrams for $\mathrm{CBO}$ of $\mathrm{Cs}_{2} \mathrm{AgBiBr}_{6} / \mathrm{SnO}_{2}$ changing from +0.19 to $-0.31 \mathrm{eV}$

\subsection{Effect of doping concentration $\left(\mathrm{N}_{\mathrm{A}}\right)$ of $\mathrm{P}_{3} \mathrm{HT}$}

Figure 8a displays the current density-voltage curves for various doping concentration of $\mathrm{P}_{3} \mathrm{HT}$ changing from $5 \times 10^{12}$ to $5 \times 10^{21} \mathrm{~cm}^{-3}$. According to this figure, the larger concentrations caused higher efficiency due to better charge transport and charge extraction at the $\mathrm{P}_{3} \mathrm{HT}$ /absorber interface. Figure $8 \mathrm{~b}$ denotes the effect of $\mathrm{N}_{\mathrm{A}}$ on the performance parameters. It determines that PCE is low at low level of $N_{A}$ which is owing to high series resistance in line with the former studies (Daraie and Fattah 2020; Jamal et al. 2020; Wang et al. 2020). Thus, according to Fig. 8b, PCE is maximized at $N_{A}=5 \times 10^{19} \mathrm{~cm}^{-3}$ and lager values. The $\mathrm{V}_{\mathrm{oc}}$ of $1.87 \mathrm{~V}, \mathrm{~J}_{\mathrm{sc}}$ of $6.39 \mathrm{~mA} / \mathrm{cm}^{2}, \mathrm{FF}$ of 0.88 , and efficiency of $10.59 \%$ are found.
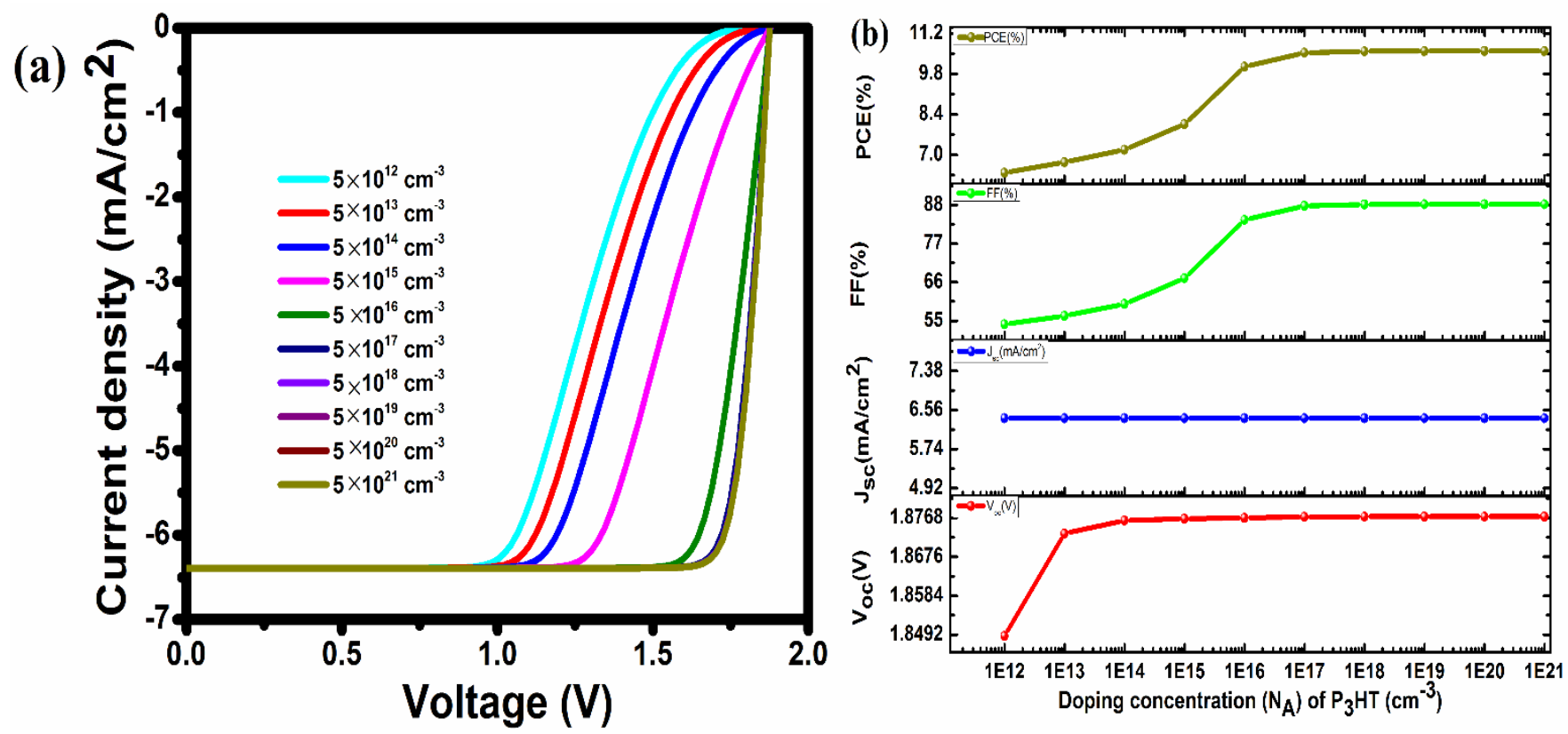

Fig. 8 a The current density-voltage curves, and $\mathbf{b}$ the performance parameters of $\mathrm{V}_{\mathrm{oc}}, \mathrm{J}_{\mathrm{sc}}, \mathrm{FF}$ and efficiency for various doping concentration, $\mathrm{N}_{\mathrm{A}}$, of $\mathrm{P}_{3} \mathrm{HT}$ changing from $5 \times 10^{12}$ to $5 \times 10^{21} \mathrm{~cm}^{-3}$ 


\subsection{Effect of doping concentration ( $\mathrm{ND}_{\mathrm{D}}$ ) of $\mathrm{SnO}_{2}$}

Figure 9 a displays the current density-voltage curves with varying doping concentration of $\mathrm{SnO}_{2}$ changing from $5 \times 10^{12}$ to $5 \times 10^{21} \mathrm{~cm}^{-3}$. According to this figure, the greater concentrations produce the better charge transport and charge extraction at the $\mathrm{SnO}_{2}$ /absorber interface. Figure $9 \mathrm{~b}$ shows the effect of $\mathrm{N}_{\mathrm{D}}$ on the performance parameters. Again it defines that PCE is low at low level of $N_{D}$ which is owing to high series resistance in agreement with aforementioned studies (Daraie and Fattah 2020; Jamal et al. 2020; Wang et al. 2020). Thus, according to Fig. 9b, PCE is maximized at $10.59 \%$ for $N_{D}=5 \times 10^{19} \mathrm{~cm}^{-3}, 10.55 \%$ for $N_{D}=5 \times 10^{20} \mathrm{~cm}^{-3}$, and $10.48 \%$ for $N_{D}=5 \times 10^{21} \mathrm{~cm}^{-3}$. As shown in Fig. $9 \mathrm{~b}$, the efficiency of $10.59 \%, \mathrm{~V}_{\mathrm{oc}}$ of $1.87 \mathrm{~V}, \mathrm{~J}_{\mathrm{sc}}$ of $6.39 \mathrm{~mA} / \mathrm{cm}^{2}$ and $\mathrm{FF}$ of 0.88 are obtained.
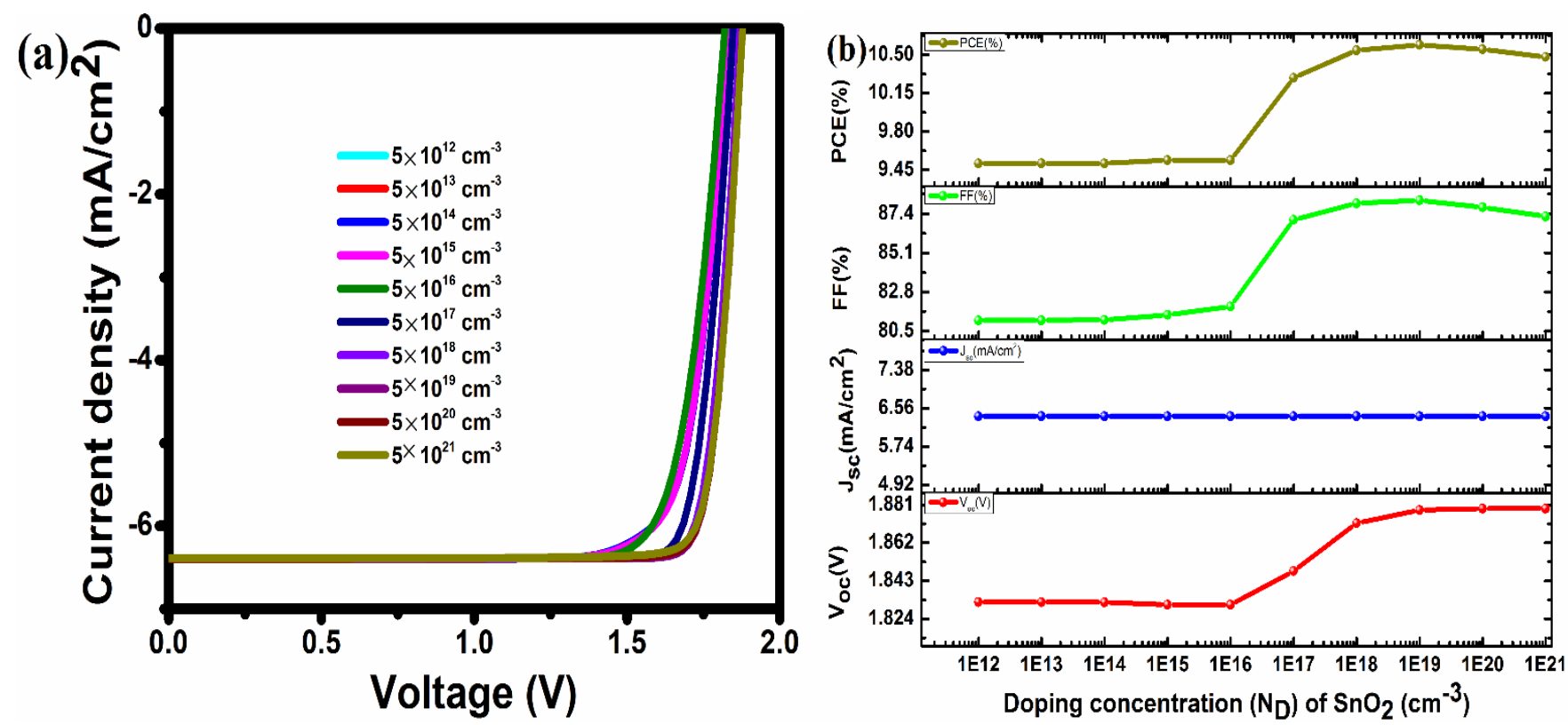

Fig. 9 a The current density-voltage curves, and $\mathbf{b}$ the performance parameters of $\mathrm{V}_{\mathrm{oc}}, \mathrm{J}_{\mathrm{sc}}$, $\mathrm{FF}$ and efficiency for different doping concentration, $\mathrm{N}_{\mathrm{D}}$, of $\mathrm{SnO}_{2}$ changing from $5 \times 10^{12}$ to $5 \times 10^{21} \mathrm{~cm}^{-3}$

\subsection{Effect of capture cross section in the absorber layer}

Figure 10 demonstrates the current density-voltage curves for $N_{t, D P}$ (defect density of absorber layer) and different capture cross section $\left(\sigma_{n, p}\right)$ varying from $10^{-20}$ to $10^{-12} \mathrm{~cm}^{2}$ (Shikoh et al. 2020; Bruzzi et al. 2020; Nithya and Sudheer 2020). After optimizing, we achieved the optimum values of $\sigma_{n, p}$ and $N_{t, D P}$ (Jamal et al. 2019; Rai et al. 2020; Teimouri et al. 2020). 

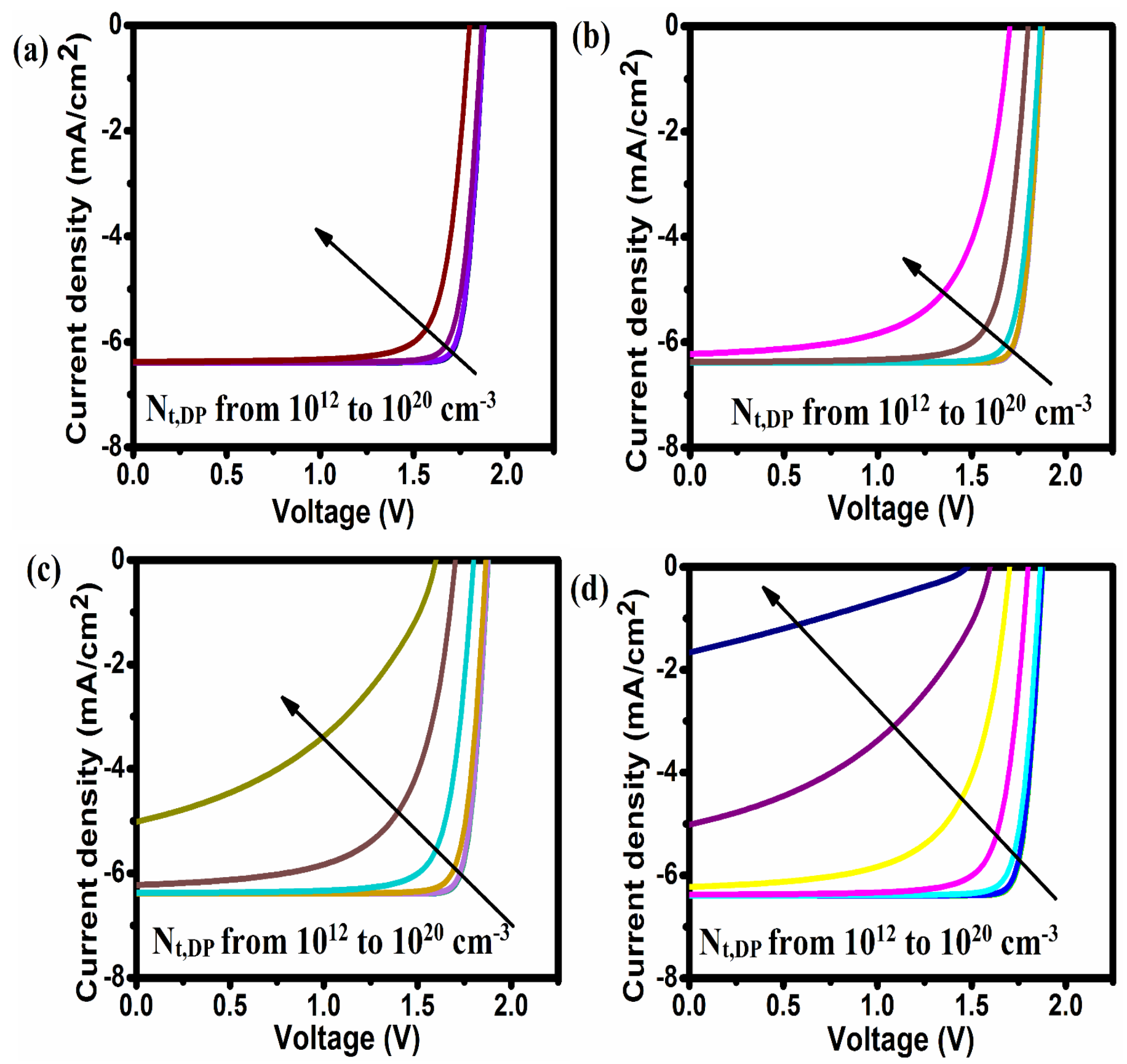
(e)

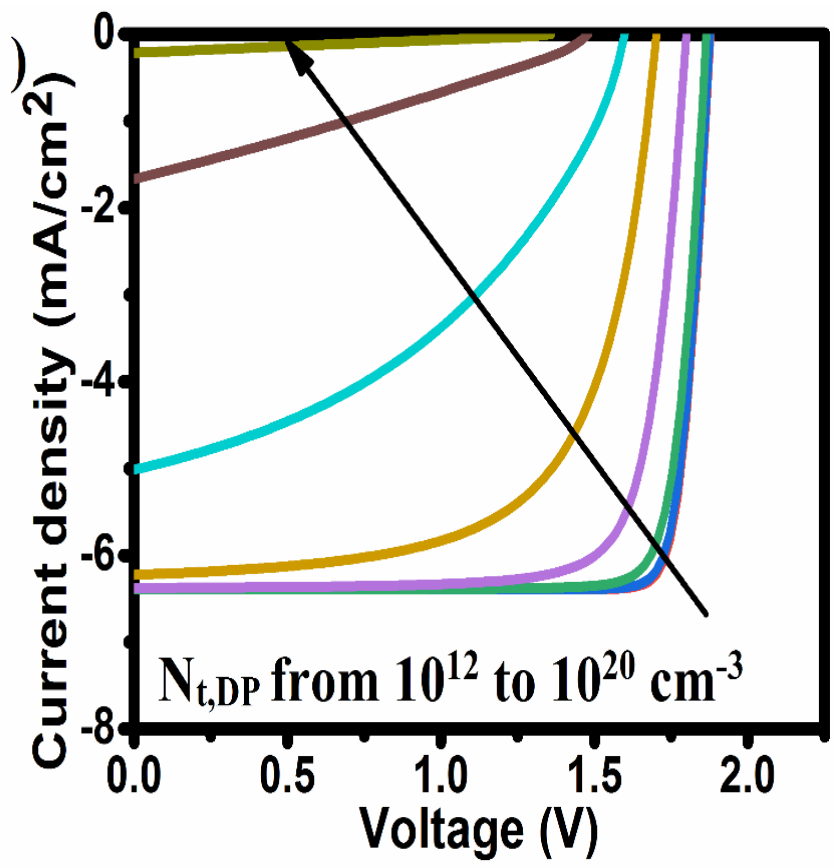

(g)

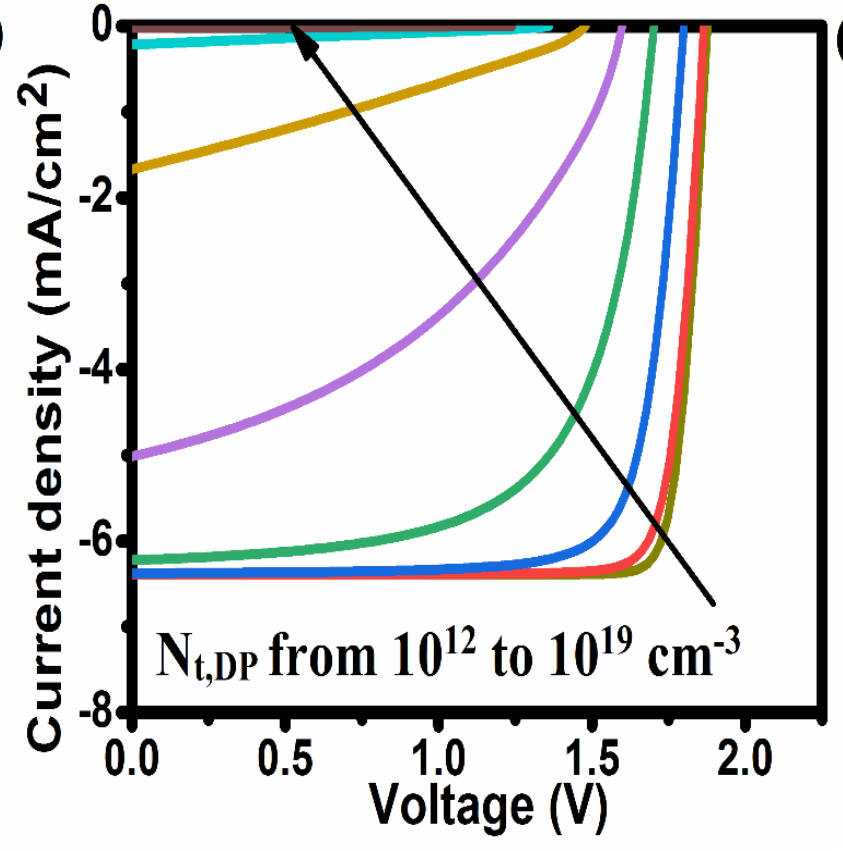

(f)

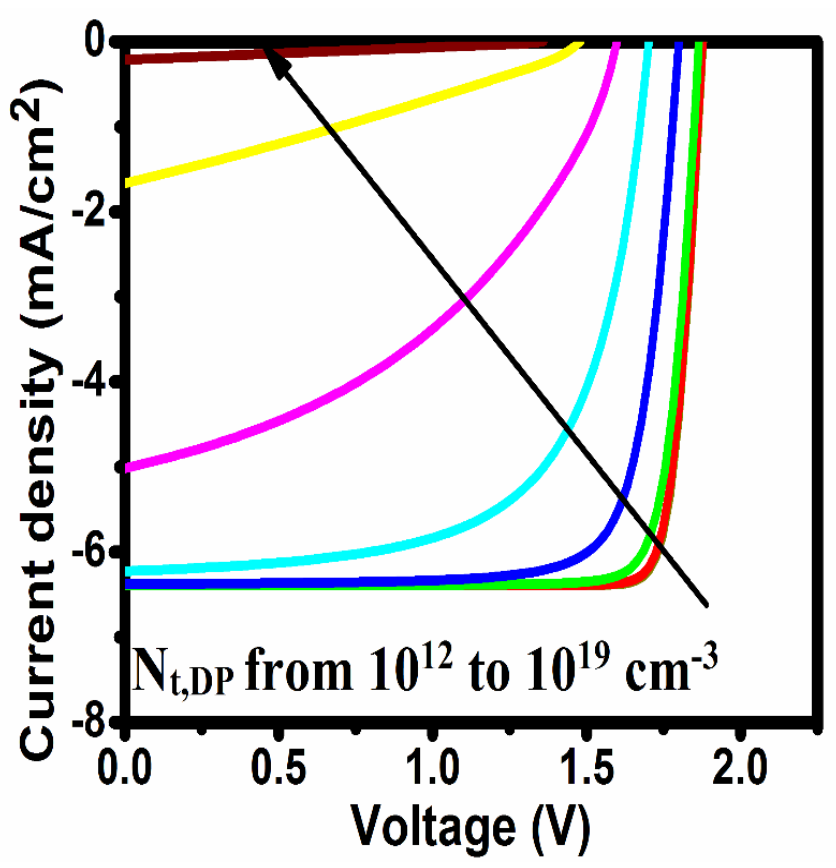

(h)

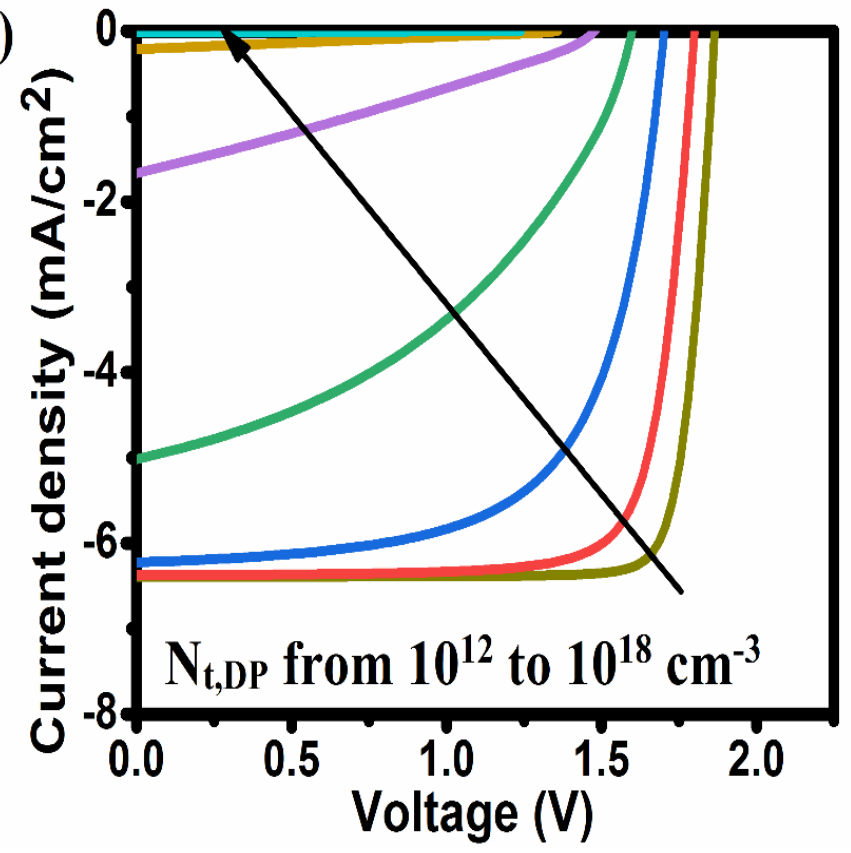




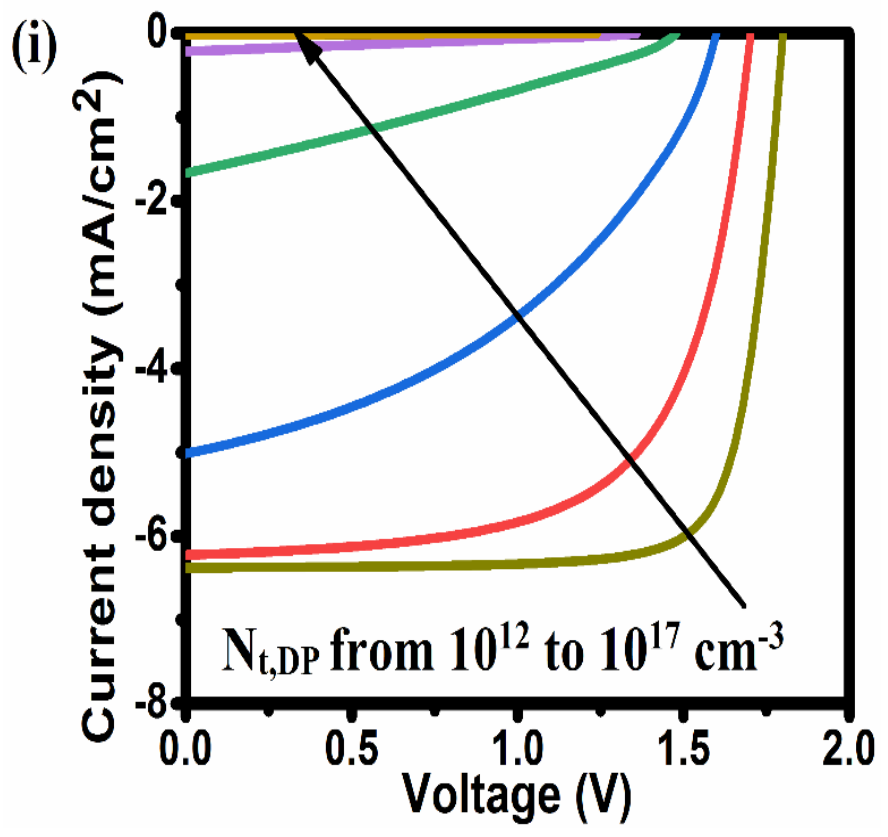

Fig. 10 The current density-voltage curves for $\mathbf{a} \sigma_{n, p}=10^{-20} \mathrm{~cm}^{2}, \mathbf{b} \sigma_{n, p}=10^{-19} \mathrm{~cm}^{2}, \mathbf{c} \sigma_{n, p}=10^{-18} \mathrm{~cm}^{2}, \mathbf{d} \sigma_{n, p}=10^{-17} \mathrm{~cm}^{2}$, e $\sigma_{n, p}=$ $10^{-16} \mathrm{~cm}^{2}, \mathbf{f} \sigma_{n, p}=10^{-15} \mathrm{~cm}^{2}, \mathbf{g} \sigma_{n, p}=10^{-14} \mathrm{~cm}^{2}, \mathbf{h} \sigma_{n, p}=10^{-13} \mathrm{~cm}^{2}$, and $\mathbf{i} \sigma_{n, p}=10^{-12} \mathrm{~cm}^{2}$

Finally, here we report the highest PCE. It should be noted that we only draw the PCE curve. We avoid to draw $V_{\text {oc }}, J_{s c}$, and FF curves. The highest PCE is achieved at optimum values of at $\sigma_{n, p}$ of $10^{-20} \mathrm{~cm}^{2}$ for $N_{t, D P}$ of $10^{16} \mathrm{~cm}^{-3}$, at $\sigma_{n, p}$ of $10^{-19} \mathrm{~cm}^{2}$ for $N_{t, D P}$ of $10^{15} \mathrm{~cm}^{-3}$, at $\sigma_{n, p}$ of $10^{-18} \mathrm{~cm}^{2}$ for $N_{t, D P}$ of $10^{14} \mathrm{~cm}^{-3}$, at $\sigma_{n, p}$ of $10^{-17} \mathrm{~cm}^{2}$ for $N_{t, D P}$ of $10^{13} \mathrm{~cm}^{-3}$, and at $\sigma_{n, p}$ of $10^{-16} \mathrm{~cm}^{2}$ for $N_{t, D P}$ of $10^{12} \mathrm{~cm}^{-3}$. According to Fig. 11, the highest efficiency of $10.60 \%, \mathrm{~V}_{\mathrm{oc}}$ of $1.87 \mathrm{~V}, \mathrm{~J}_{\mathrm{sc}}$ of $6.39 \mathrm{~mA} / \mathrm{cm}^{2}$, and $\mathrm{FF}$ of 0.88 are obtained.
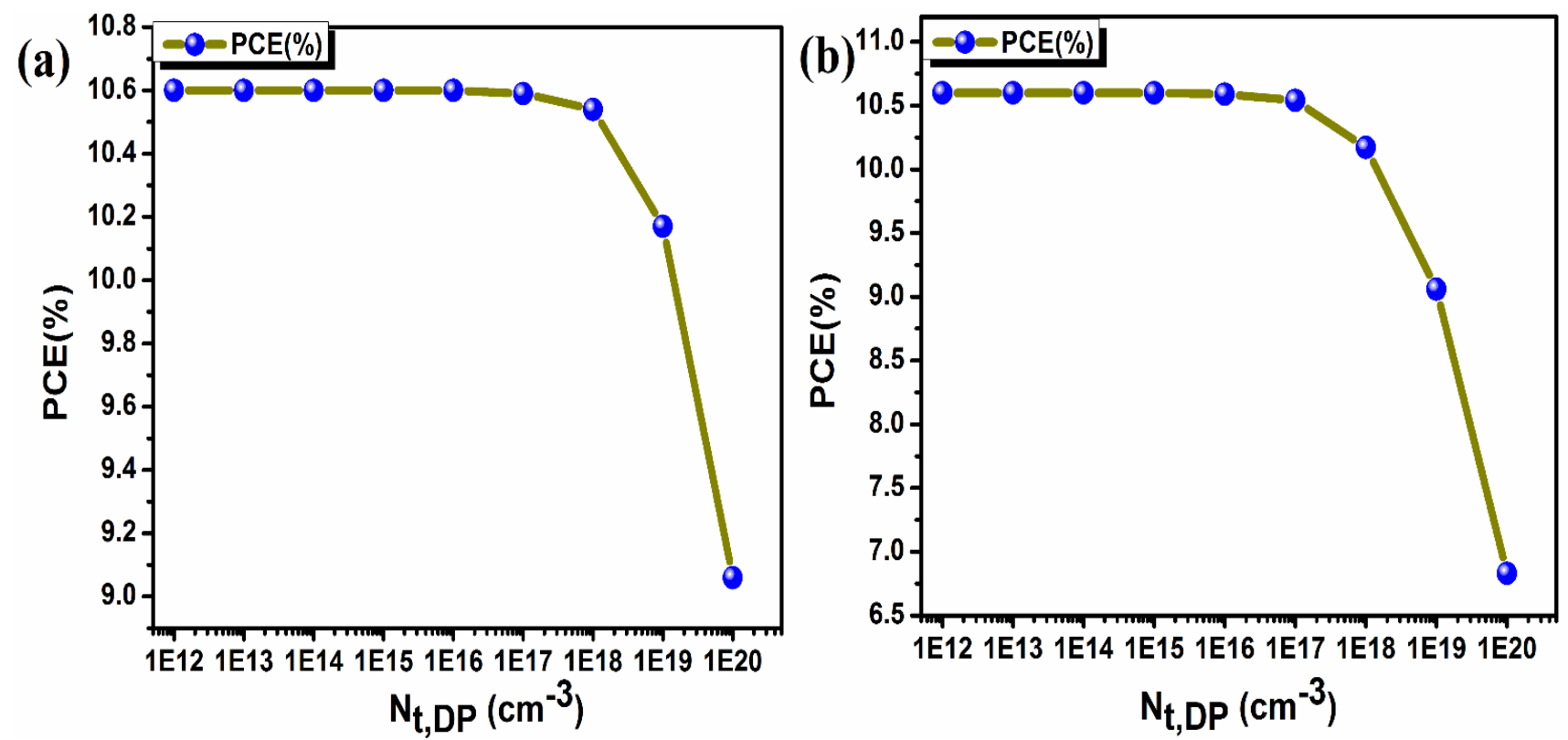

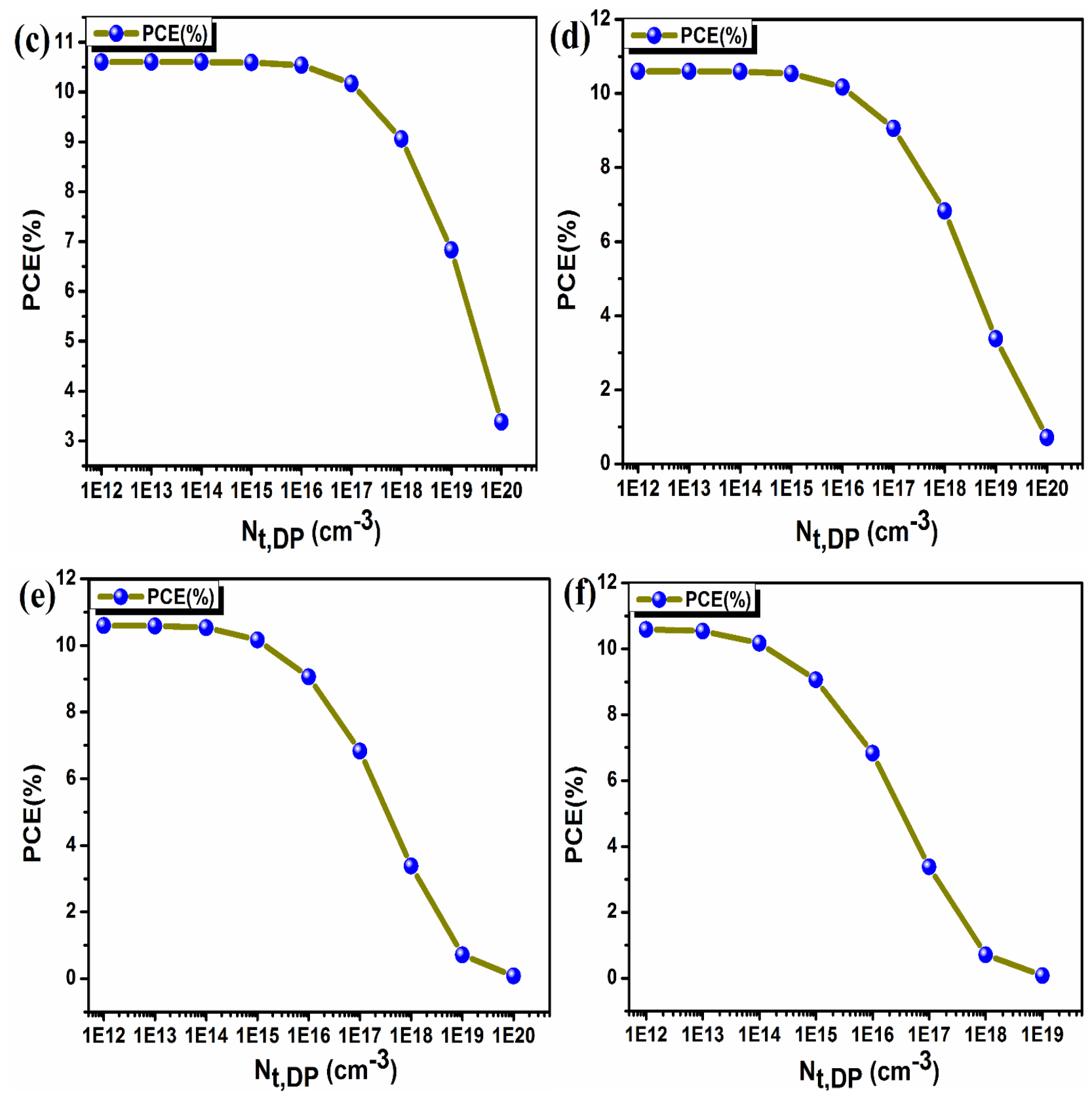

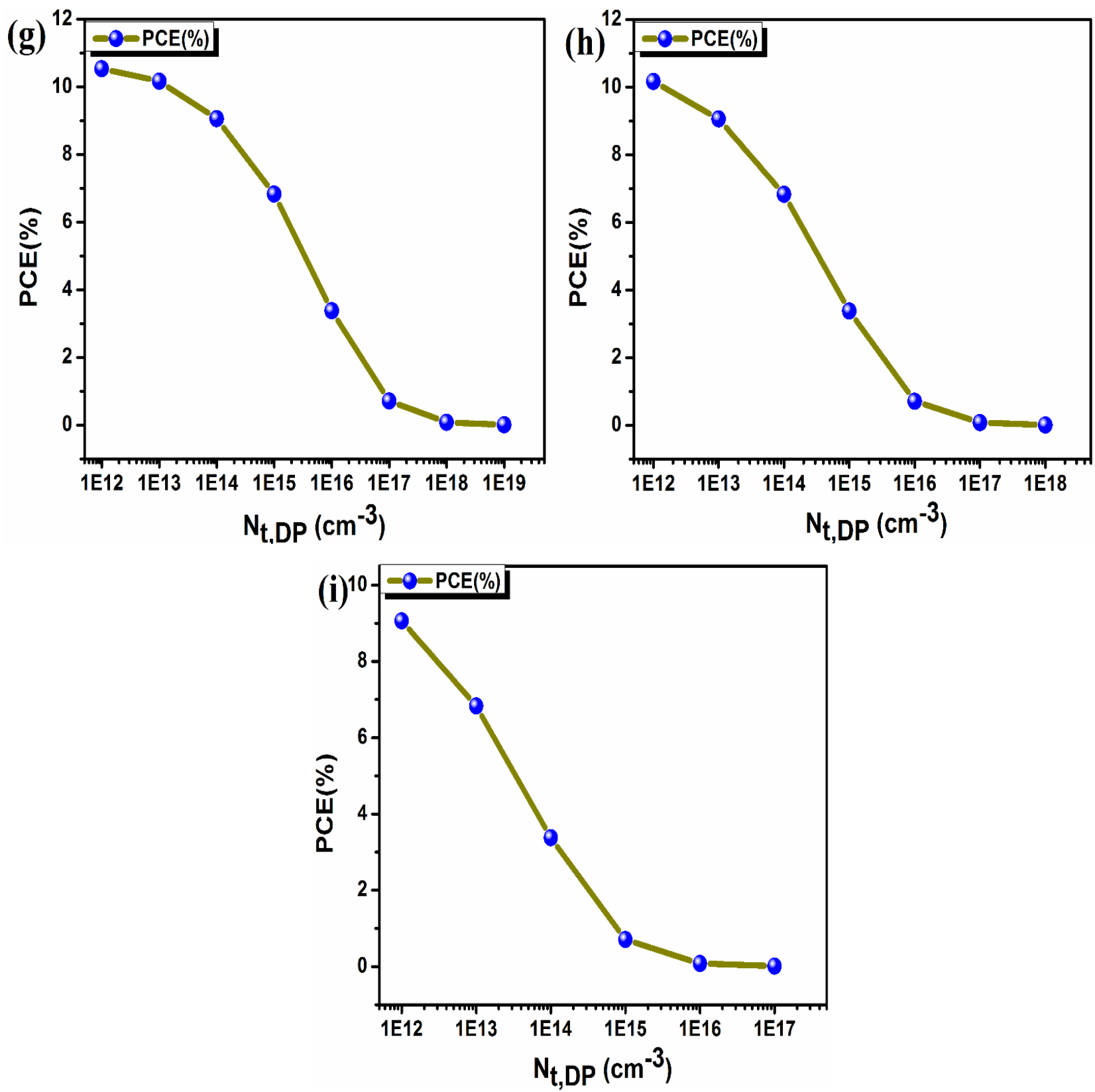

Fig. 11 The PCE of solar cell against defect density of double perovskite for $\mathbf{a} \sigma_{n, p}=10^{-20} \mathrm{~cm}^{2}, \mathbf{b} \sigma_{n, p}=$ $10^{-19} \mathrm{~cm}^{2}, \mathbf{c} \sigma_{n, p}=10^{-18} \mathrm{~cm}^{2}, \mathbf{d} \sigma_{n, p}=10^{-17} \mathrm{~cm}^{2}, \mathbf{e} \sigma_{n, p}=10^{-16} \mathrm{~cm}^{2}, \mathbf{f} \sigma_{n, p}=10^{-15} \mathrm{~cm}^{2}, \mathbf{g} \sigma_{n, p}=10^{-14} \mathrm{~cm}^{2}, \mathbf{h} \sigma_{n, p}=$ $10^{-13} \mathrm{~cm}^{2}$, and $\mathbf{i} \sigma_{n, p}=10^{-12} \mathrm{~cm}^{2}$

\subsection{Effect of interface defect density of $\mathrm{P}_{3} \mathrm{HT} / \mathrm{Cs}_{2} \mathrm{AgBiBr}_{6}$ and $\mathrm{Cs}_{2} \mathrm{AgBiBr}_{6} / \mathrm{SnO}_{2}$}

The serious factor of $\mathrm{Cs}_{2} \mathrm{AgBiBr}_{6}$ and $\mathrm{P}_{3} \mathrm{HT}$ or $\mathrm{Cs}_{2} \mathrm{AgBiBr}_{6}$ and $\mathrm{SnO}_{2}$ interfaces is band offset which controls the carrier recombination at the interface and it affects $\mathrm{V}_{\mathrm{oc}}$. The $\mathrm{V}_{\mathrm{oc}}$, $\mathrm{J}_{\mathrm{sc}}$, and FF curves are not shown in Fig. 12, we only draw the PCE curve. According to Fig. 12, $\mathrm{PCE}$ is plotted against interface defect density of $\mathrm{P}_{3} \mathrm{HT} / \mathrm{Cs}_{2} \mathrm{AgBiBr}_{6}$ and $\mathrm{Cs}_{2} \mathrm{AgBiBr}_{6} / \mathrm{SnO}_{2}$. As shown in Fig. 12a, the PCE is depicted against interface defect density of $P_{3} H T / C_{2} A_{g B i B r}$ changing from $10^{12}$ to $10^{18} \mathrm{~cm}^{-2}$. Figure $12 \mathrm{~b}$ represents $\mathrm{PCE}$ against interface defect density of $\mathrm{Cs}_{2} \mathrm{AgBiBr}_{6} / \mathrm{SnO}_{2}$ changing from $10^{7}$ to $10^{14} \mathrm{~cm}^{-}$ 2. As shown in Fig. 12a, PCE is initiated from $10.60 \%$ at interface defect density of $10^{12}, 10^{13}$, and $10^{14} \mathrm{~cm}^{-2}$, decreased to $10.59 \%$ at $10^{15} \mathrm{~cm}^{-2}, 10.58 \%$ at $10^{16} \mathrm{~cm}^{-2}, 10.54 \%$ at $10^{17} \mathrm{~cm}^{-2}$, and $10.51 \%$ at $10^{18} \mathrm{~cm}^{-2}$. As far as this figure is concerned, the optimum value of $10^{14} \mathrm{~cm}^{-2}$ is obtained, with PCE of $10.60 \%, \mathrm{~V}_{\text {oc }}$ of $1.87 \mathrm{~V}, \mathrm{~J}_{\mathrm{sc}}$ of $6.39 \mathrm{~mA} / \mathrm{cm}^{2}$, and FF of 0.88 . According to Fig. $12 \mathrm{~b}$, PCE is started from $10.61 \%$ at $10^{7}, 10^{8}$, and $10^{9} \mathrm{~cm}^{-2}$, reduced to $10.60 \%$ at $10^{10} \mathrm{~cm}^{-2}$, $10.55 \%$ at $10^{11} \mathrm{~cm}^{-2}, 10.24 \%$ at $10^{12} \mathrm{~cm}^{-2}, 9.41 \%$ at $10^{13} \mathrm{~cm}^{-2}$, and $8.40 \%$ at $10^{14} \mathrm{~cm}^{-2}$. As shown in this figure, the optimum value is occurred at $10^{9} \mathrm{~cm}^{-2}$, with PCE of $10.61 \%, \mathrm{~V}_{\text {oc }}$ of $1.88 \mathrm{~V}, \mathrm{~J}_{\mathrm{sc}}$ of $6.39 \mathrm{~mA} / \mathrm{cm}^{2}$, and FF of 0.88 . 

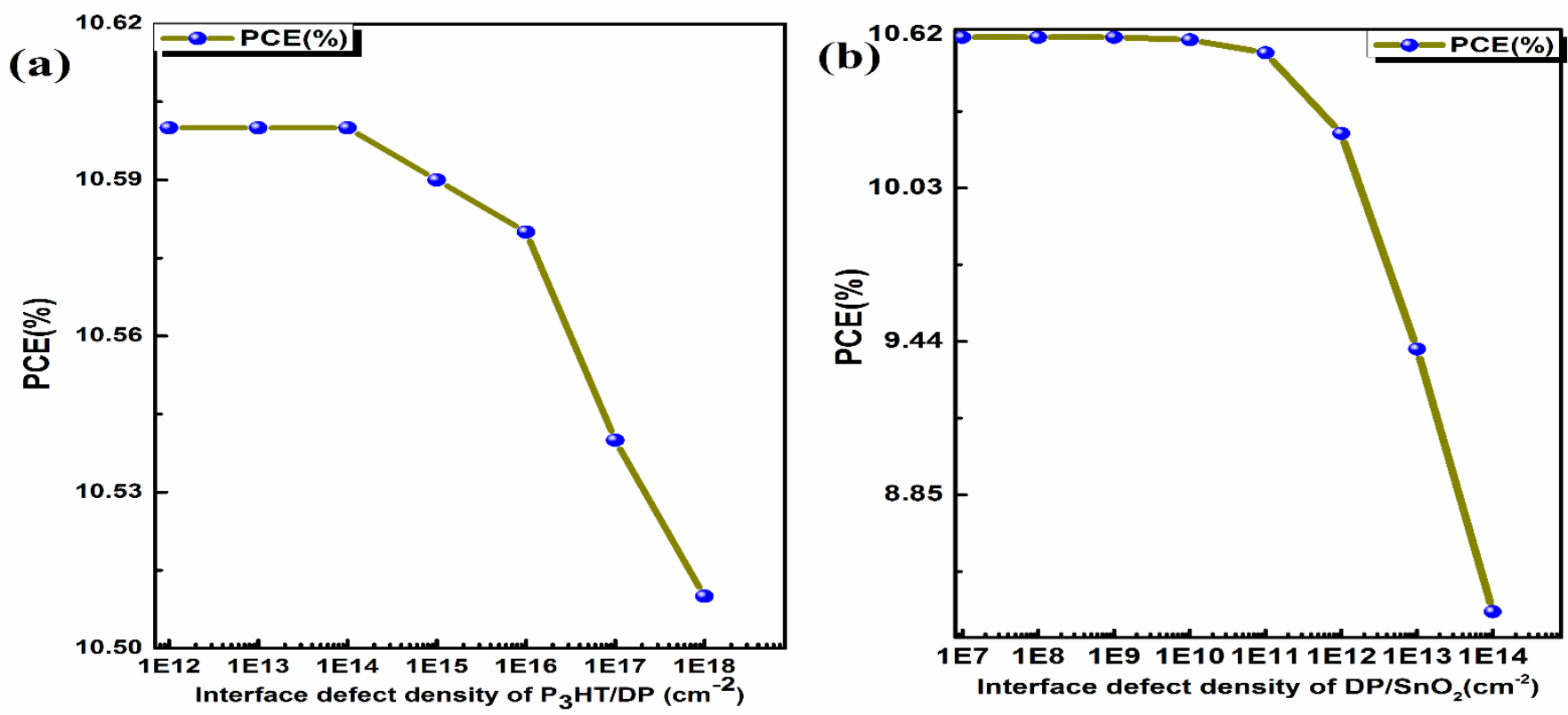

Fig. 12 a PCE against interface defect density of $\mathrm{P}_{3} \mathrm{HT} / \mathrm{Cs}_{2} \mathrm{AgBiBr}_{6}$ changing from $10^{12}$ to $10^{18} \mathrm{~cm}^{-2}$. b PCE against interface defect density of $\mathrm{Cs}_{2} \mathrm{AgBiBr}_{6} / \mathrm{SnO}_{2}$ varying from $10^{7}$ to $10^{14} \mathrm{~cm}^{-2}$

\subsection{Effect of radiative recombination of $\mathrm{Cs}_{2} \mathrm{AgBiBr} 6$}

In $\mathrm{Cs}_{2} \mathrm{AgBiBr}_{6}$, the Shockley-Reed-Hall (SRH) and radiative recombination are the most prominent recombinations (Islam et al. 2020). However, there is Auger recombination in $\mathrm{Cs}_{2} \mathrm{AgBiBr}_{6}$ when the double perovskite material is highly doped (Jani et al. 2020). Figure 13a represents the current density-voltage curves and Fig. 13b shows the PCE against radiative recombination changing from $2.3 \times 10^{-8}$ to $2.3 \times 10^{-14} \mathrm{~cm}^{3} / \mathrm{s}$. According to Fig. $13 \mathrm{~b}$, the amount of radiative recombination is maximized at $2.3 \times 10^{-13} \mathrm{~cm}^{3} / \mathrm{s}$, with efficiency of $11.69 \%, \mathrm{~V}_{\text {oc }}$ of $2.03 \mathrm{~V}, \mathrm{~J}_{\mathrm{sc}}$ of $6.39 \mathrm{~mA} / \mathrm{cm}^{2}$, and $\mathrm{FF}$ of 0.90. The $V_{o c}, J_{s c}$ and FF curves are not shown. In addition to current density-voltage, we only draw the PCE curve.
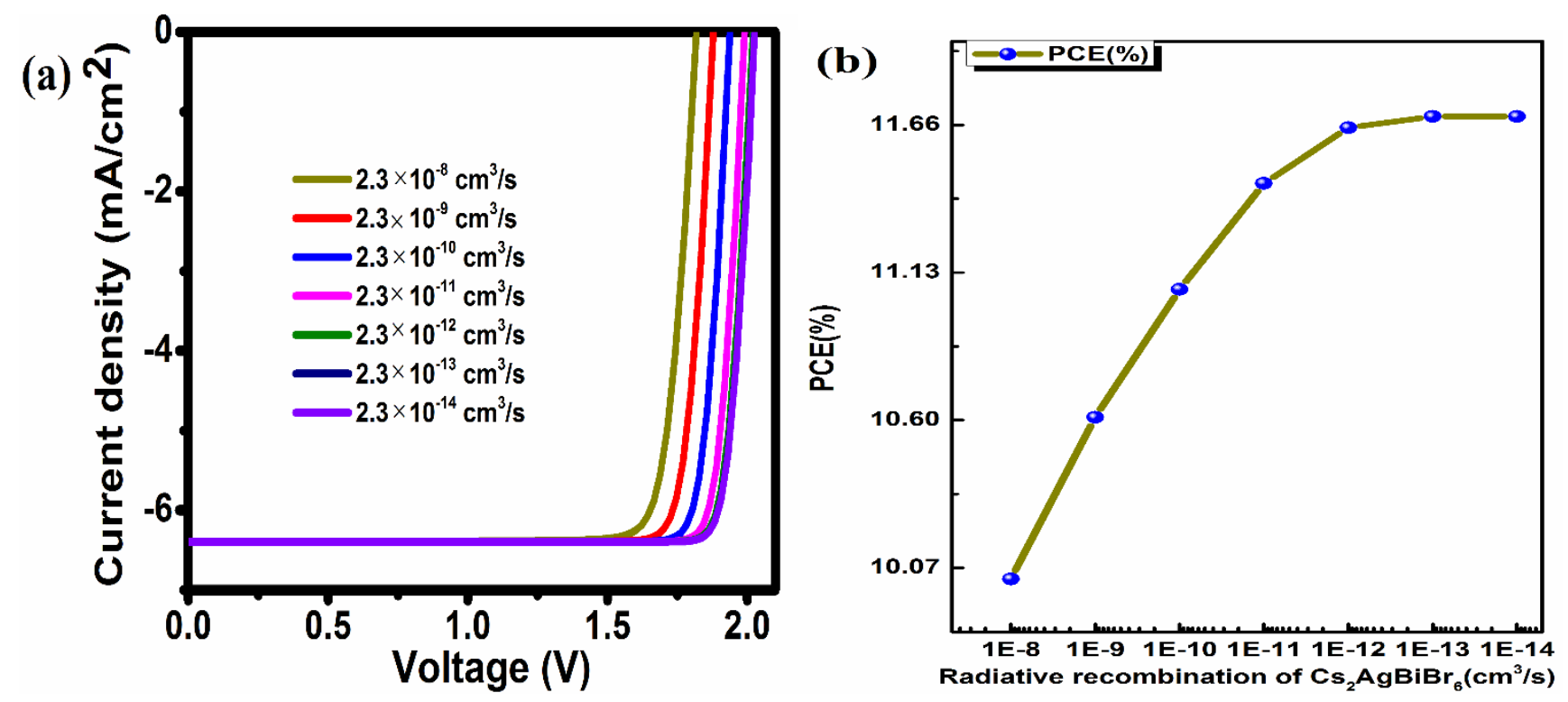

Fig. 13 a The current density-voltage curves for radiative recombination of $\mathrm{Cs}_{2} \mathrm{AgBiBr}_{6}$, b PCE against radiative recombination of $\mathrm{Cs}_{2} \mathrm{AgBiBr}_{6}$ changing from $2.3 \times 10^{-8}$ to $2.3 \times 10^{-14} \mathrm{~cm}^{3} / \mathrm{s}$ 
As Fig. 14a shows, after performing all these optimizations for device of ITO/SnO ${ }_{2} / \mathrm{Cs}_{2} \mathrm{AgBiBr}_{6} / \mathrm{P}_{3} \mathrm{HT} / \mathrm{Au}$, the performance parameters of $\mathrm{V}_{\text {oc }}$ of $2.03 \mathrm{~V}, \mathrm{~J}_{\mathrm{sc}}$ of $6.39 \mathrm{~mA} / \mathrm{cm}^{2}, \mathrm{FF}$ of 0.90 , and PCE of $11.69 \%$ are attained. For this device, the external quantum efficiency is depicted in Fig. 14b. As shown in this figure, the external quantum efficiency is commenced at the wavelength of $330 \mathrm{~nm}$ and improved rapidly to $58.87 \%$ at $340 \mathrm{~nm}$ and then reduced to zero at $610 \mathrm{~nm}$.

(a)

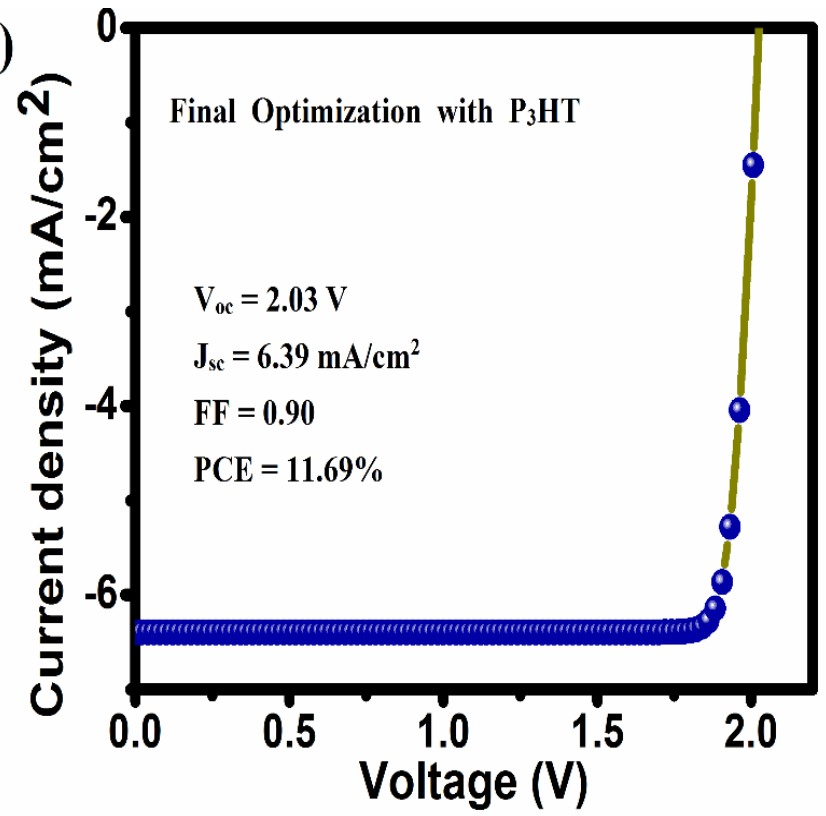

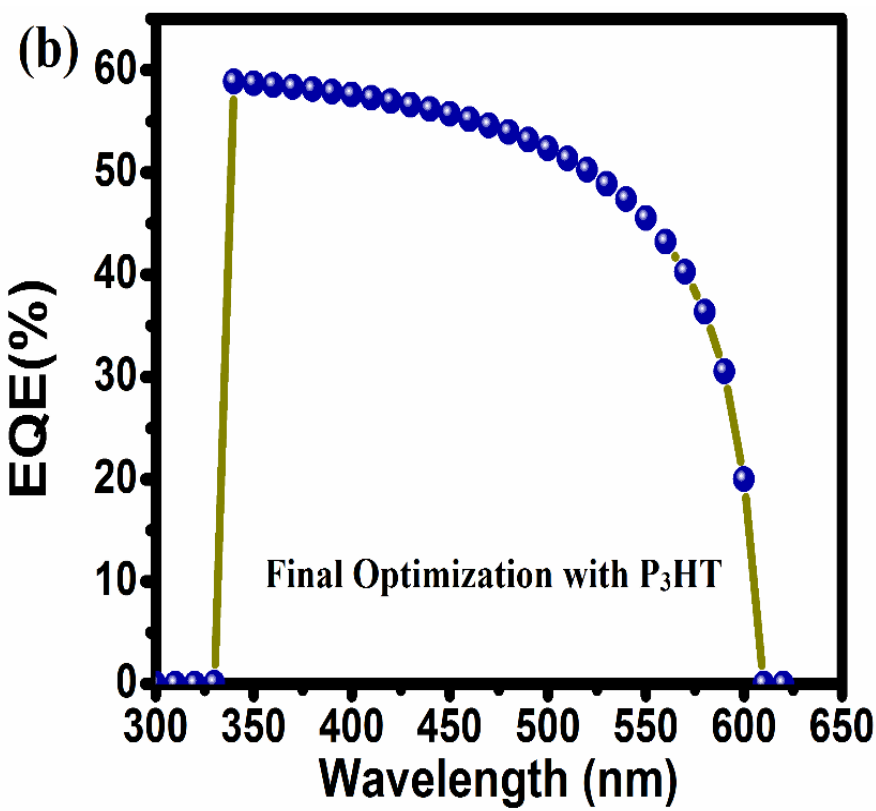

Fig. 14 a The current density-voltage curve, and $\mathbf{b}$ the calculated external quantum efficiency for ITO/SnO $/ \mathrm{TS}_{2} \mathrm{AgBiBr} 6 / \mathrm{P}_{3} \mathrm{HT} / \mathrm{Au}$ cell, after doing all optimization using SCAPS

In this step, we examined the other $\mathrm{HTL}$, named $\mathrm{Cu}_{2} \mathrm{O}$. Figure $15 \mathrm{a}$ exhibits the current density-voltage curve and Fig. 15b illustrates the external quantum efficiency, for ITO/SnO${ }_{2} / \mathrm{Cs}_{2} \mathrm{AgBiBr}_{6} / \mathrm{Cu}_{2} \mathrm{O} / \mathrm{Au}$ cell. After optimizing the mentioned parameters, the performance parameters are obtained as $\mathrm{V}_{\mathrm{oc}}$ of $1.97 \mathrm{~V}, \mathrm{~J}_{\mathrm{sc}}$ of $6.39 \mathrm{~mA} / \mathrm{cm}^{2}, \mathrm{FF}$ of 0.895 $(89.5 \%)$ and efficiency of $11.32 \%$. As specified by Fig. 15b, the external quantum efficiency is started at the wavelength of $300 \mathrm{~nm}$ and enlarged rapidly to the apex of $59.34 \%$ at $340 \mathrm{~nm}$ and then decreased to zero at $610 \mathrm{~nm}$.
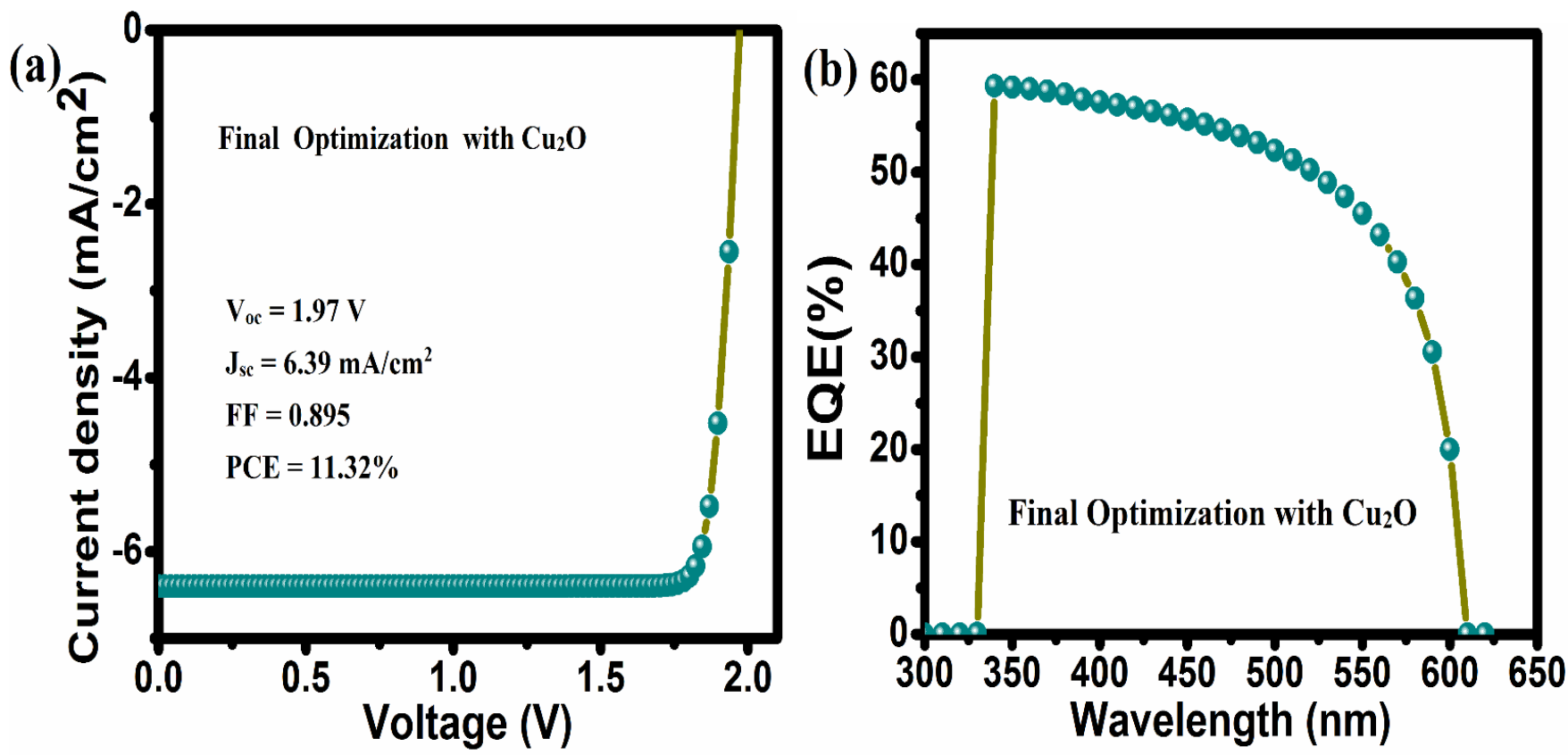

Fig. 15 a The current density-voltage curve, and $\mathbf{b}$ the computed external quantum efficiency for ITO/SnO $\mathrm{I}_{2} / \mathrm{Cs}_{2} \mathrm{AgBiBr} 6 / \mathrm{Cu}_{2} \mathrm{O} / \mathrm{Au}$ cell, after doing all optimization using SCAPS 
Double perovskites are a new class of material with good inherent stability. After performing all optimization, for both $\mathrm{P}_{3} \mathrm{HT}$ and $\mathrm{Cu}_{2} \mathrm{O}$, the PCE of $11.69 \%$ and $11.32 \%$ are achieved, respectively. It is required to mention that, the PCE of $7.92 \%$ were reported in the simulation studies of $\mathrm{Cs}_{2} \mathrm{AgBiBr}_{6}$, employing different ETL and HTL layers (Savory et al. 2016).

As shown in Fig. 4, If the thickness of $\mathrm{Cs}_{2} \mathrm{AgBiBr}_{6}$ is chosen $600 \mathrm{~nm}$ (Islam et al. 2020), after doing the same procedure as mentioned in this manuscript, PCE of $8.47 \%, \mathrm{~V}_{\mathrm{oc}}$ of $1.97 \mathrm{~V}, \mathrm{~J}_{\mathrm{sc}}$ of $4.73 \mathrm{~mA} / \mathrm{cm}^{2}$, and FF of 0.908 were obtained, which means that the efficiency of device is increased theoretically by $488.19 \%$ compared to the experiment. And for the other double perovskite, $\mathrm{Cs}_{2} \mathrm{TiBr}_{6}$, the thickness of this double perovskite is obtained as $800 \mathrm{~nm}$ (Jani et al. 2020). We are performing the same procedure in this thickness, PCE of $9.95 \%, \mathrm{~V}_{\mathrm{oc}}$ of $2.01 \mathrm{~V}, \mathrm{~J}_{\mathrm{sc}}$ of $5.47 \mathrm{~mA} / \mathrm{cm}^{2}$, and FF of 0.90 were attained, which means that PCE is enhanced theoretically by $590.97 \%$ against the experiment.

\section{Conclusion}

In conclusion, due to the existing of lead in the structure of perovskite solar cell as well as the inherent low efficiency of the double perovskite solar cell, the current study aims to overcome the mentioned shortcomings by comparing two HTLs using SCAPS software. Two devices with two different HTLs were examined, $\mathrm{P}_{3} \mathrm{HT}$ and $\mathrm{Cu}_{2} \mathrm{O}$. For both devices, an optimal thickness of $1200 \mathrm{~nm}$ and defect density of $1.0 \times 10^{14} \mathrm{~cm}^{-3}$ for $\mathrm{Cs}_{2} \mathrm{AgBiBr}_{6}$ layer were attained. For both devices, the highest efficiency is obtained as $\mathrm{CBO}$ of $-0.21 \mathrm{eV}$ and $\mathrm{VBO}$ of $+0.16 \mathrm{eV}$. For shallow acceptor doping concentration of $\mathrm{HTLs}\left(\mathrm{P}_{3} \mathrm{HT}\right.$ and $\left.\mathrm{Cu}_{2} \mathrm{O}\right)$, the values of $5 \times 10^{19}$ and $5 \times 10^{17} \mathrm{~cm}^{-3}$ were obtained, respectively. As far as the shallow donor density of ETLs is concerned, for both cases, we achieved the optimal value of $5 \times 10^{19} \mathrm{~cm}^{-3}$. The optimal values of capture cross section $\left(\sigma_{n, p}\right)$ in absorber layer for both HTLs are achieved to be $\sigma_{n, p}$ of $10^{-20} \mathrm{~cm}^{2}$ for $N_{t, D P}$ of $10^{16} \mathrm{~cm}^{-3}, \quad \sigma_{n, p}$ of $10^{-19} \mathrm{~cm}^{2}$ for $\quad N_{t, D P}$ of $10^{15} \mathrm{~cm}^{-3}, \quad \sigma_{n, p}$ of $10^{-18} \mathrm{~cm}^{2}$ for $N_{t, D P}$ of $10^{14} \mathrm{~cm}^{-3}$, $\sigma_{n, p}$ of $10^{-17} \mathrm{~cm}^{2}$ for $N_{t, D P}$ of $10^{13} \mathrm{~cm}^{-3}$, and $\sigma_{n, p}$ of $10^{-16} \mathrm{~cm}^{2}$ for $N_{t, D P}$ of $10^{12} \mathrm{~cm}^{-3}$. For $\mathrm{P}_{3} \mathrm{HT}$ device, the optimum value of the interface defect density of $\mathrm{P}_{3} \mathrm{HT} / \mathrm{Cs}_{2} \mathrm{AgBiBr}_{6}$ is occurred at $1.0 \times 10^{14} \mathrm{~cm}^{-2}$, and for $\mathrm{Cs}_{2} \mathrm{AgBiBr}_{6} / \mathrm{SnO}_{2}$ is happened at $1.0 \times 10^{9} \mathrm{~cm}^{-2}$. For $\mathrm{Cu}_{2} \mathrm{O}$ device, the optimal value of the interface defect density of $\mathrm{Cu}_{2} \mathrm{O} / \mathrm{Cs}_{2} \mathrm{AgBiBr}_{6}$ is befallen at $1.0 \times 10^{13} \mathrm{~cm}^{-2}$, and for $\mathrm{Cs}_{2} \mathrm{AgBiBr}_{6} / \mathrm{SnO}_{2}$ is taken place at $1.0 \times 10^{10} \mathrm{~cm}^{-2}$. About radiative recombination, for $\mathrm{P}_{3} \mathrm{HT}$ device, the optimal value is happened at $2.3 \times 10^{-13} \mathrm{~cm}^{3} / \mathrm{s}$, however, for $\mathrm{Cu}_{2} \mathrm{O}$ device is occurred at $2.3 \times 10^{-12}$ $\mathrm{cm}^{3} / \mathrm{s}$. Finally, for $\mathrm{P}_{3} \mathrm{HT}$ device, PCE of $11.69 \%\left(\mathrm{~V}_{\text {oc }}\right.$ of $2.02 \mathrm{~V}, \mathrm{~J}_{\mathrm{sc}}$ of $6.39 \mathrm{~mA} / \mathrm{cm}^{2}$, and $\mathrm{FF}$ of $\left.0.90(90 \%)\right)$ were accomplished, and for $\mathrm{Cu}_{2} \mathrm{O}$ device, a PCE of $11.32 \%\left(\mathrm{~V}_{\mathrm{oc}}\right.$ of $1.97 \mathrm{~V}, \mathrm{~J}_{\mathrm{sc}}$ of $6.39 \mathrm{~mA} / \mathrm{cm}^{2}$, and $\mathrm{FF}$ of $\left.0.895(89.5 \%)\right)$ were attained. To sum up, the PCE for $\mathrm{P}_{3} \mathrm{HT}$ device has been enhanced theoretically by $711.80 \%$, and for $\mathrm{Cu}_{2} \mathrm{O}$ device has been enlarged by $686.11 \%$ compared with the $1.44 \%$ efficiency reported in the experiment. The future research could be undertaken in these kind of double perovskite materials, due to having vigorous stability against decomposition and demonstrates flexible tunability band gaps of optoelectronic properties in the range of infrared to ultraviolet. Overall, the elicited results suggest that $\mathrm{Cs}_{2} \mathrm{AgBiBr}_{6}$ and some other double perovskites can play a momentous role as an absorbing layer towards the highly efficient lead-free and inorganic PSC technology, in designing eco-friendly PSC for future technologies.

Acknowledgement The authors would desire to acknowledge Professor Marc Burgelman from the Department of Electronics and Information Systems, University of Gent for the development of the SCAPS software and permitting its use.

\section{References}

Ahmed, S., Jannat, F., Khan, M.A.K., Alim, M.A.: Numerical development of eco-friendly $\mathrm{Cs}_{2} \mathrm{TiBr}_{6}$ based perovskite solar cell with allinorganic charge transport materials via SCAPS-1D. Optik 225, 165765 (2021).https://doi.org/10.1016/j.ijleo.2020.165765

Bouich, A., Marí, B., Atourki, L., Ullah, S., Touhami, M.E.: Shedding Light on the Effect of Diethyl Ether Antisolvent on the Growth of $\left(\mathrm{CH}_{3} \mathrm{NH}_{3}\right) \mathrm{Pbl}_{3}$ Thin Films. JOM 73(2), 551-557 (2021). https://doi.org/10.1007/s11837-020-04518-5

Bouich, A., Ullah, S., Marí, B., Atourki, L., Touhami, M.E.: One-step synthesis of $\mathrm{FA}_{1-\mathrm{x}} \mathrm{GA}_{\mathrm{x}} \mathrm{Pbl}_{3}$ perovskites thin film with enhanced stability of alpha ( $\alpha$ ) phase. Mater. Chem. Phys. 258, 123973 (2021). https://doi.org/10.1016/j.matchemphys.2020.123973

Bruzzi, M., Falsini, N., Calisi, N., Vinattieri, A.: Electrically Active Defects in Polycrystalline and Single Crystal Metal Halide Perovskite. Energies 13(7), 1643 (2020). https://doi.org/10.3390/en13071643

Burgelman, M., Nollet, P., Degrave, S.: Modeling Polycrystalline Semiconductor Solar Cells. Thin Solid Films 361, 527-532 (2000). https://doi.org/10.1016/s0040-6090(99)00825-1

Burwig, T., Guc, M., Izquierdo-Roca, V., Pistor, P.: Synthesis and Crystal Structure Evolution of Co-Evaporated $\mathrm{Cs}_{2} \mathrm{AgBiBr}_{6} \mathrm{Thin}_{\mathrm{B}} \mathrm{Films}$ upon Thermal Treatment. J. Phys. Chem. C 124(17), 9249-9255 (2020). https://doi.org/10.1021/acs.jpcc.0c02480

Chen, M., Ju, M.-G., Carl, A.D., Zong, Y., Grimm, R.L., Gu, J., Zeng, X.C., Zhou, Y., Padture, N.P.: Cesium titanium (IV) bromide thin films based stable lead-free perovskite solar cells. Joule 2(3), 558-570 (2018). https://doi.org/10.1016/j.joule.2018.01.009

Chow, P.C.Y., Someya, T.: Organic photodetectors for next-generation wearable electronics. Adv. Mater. 32(15), 1902045 (2020). https://doi.org/10.1002/adma.201902045

Coulibaly, A.B., Oyedele, S.O., Kre, N'.R., Aka, B.: Comparative study of lead-free perovskite solar cells using different Hole Transporter Materials. MNSMS 9(4), 97-107 (2019). https://doi.org/10.4236/mnsms.2019.94006

Dang, Y., Tong, G., Song, W., Liu, Z., Qiu, L., Ono, L.K., Qi, Y.: Interface engineering strategies towards $\mathrm{Cs}_{2} \mathrm{AgBiBr} \mathrm{r}_{6}$ single-crystalline photodetectors with good Ohmic contact behaviors. J. Mater. Chem. C 8(1), 276-284 (2020). https://doi.org/10.1039/c9tc04780h 
Daraie, A., Fattah, A.: Performance improvement of perovskite heterojunction solar cell using graphene. Opt. Mater. 109, 110254 (2020). https://doi.org/10.1016/j.optmat.2020.110254

Du, K.-Z., Meng, W., Wang, X., Yan, Y., Mitzi, D.B.: Bandgap engineering of lead-free double perovskite $\mathrm{Cs}_{2} \mathrm{AgBiBr}_{6}$ through Trivalent Metal Alloying. Angew. Chem. Int. Ed. 56(28), 8158-8162 (2017). https://doi.org/10.1002/anie.201703970

Ganvir, R., Modelling of the nanowire CdS-CdTe device for enhanced quantum efficiency in window-absorber type solar cells. Theses and Dissertation-Electrical and Computer Engineering, University of Kentucky (2016). http://dx.doi.org/10.13023/ETD.2016.036

Ghasemi, M., Zhang, L., Yun, J.-H., Hao, M., He, D., Chen, P., Bai, Y., Lin, T., Xiao, M., Du, A., Lyu, M., Wang, L.: Dual-Ion-Diffusion Induced Degradation in Lead-Free $\mathrm{Cs}_{2} \mathrm{AgBiBr}_{6}$ Double Perovskite Solar Cells. Adv. Funct. Mater. 30(42), 2002342 (2020). https://doi.org/10.1002/adfm.202002342

Giustino, F., Snaith, H.J.: Toward lead-free perovskite solar cells. ACS Energy Lett. 1(6), 1233-1240 (2016). https://doi.org/10.1021/acsenergylett.6b00499

Gu, S., Lin, R., Han, Q., Gao, Y., Tan, H., Zhu, J.: Tin and mixed lead-tin halide perovskite solar cells: progress and their application in tandem solar cells. Adv. Mater. 32(27), 1907392 (2020). https://doi.org/10.1002/adma.201907392

He, T., Jiang, Y., Xing, X., Yuan, M.: Structured perovskite light absorbers for efficient and stable Photovoltaics. Adv. Mater. 32(26), 1903937 (2020). https://doi.org/10.1002/adma.201903937

Islam, M.T., Jani, M.R., Al Amin, S.M., Sami, M.S.U., Shorowordi, K.M., Hossain, M.I., Devgun, M., Chowdhury, S., Banerje, S., Ahmed, S.: Numerical simulation studies of a fully inorganic $\mathrm{Cs}_{2} \mathrm{AgBiBr}_{6}$ perovskite solar device. Opt. Mater. 105, 109957 (2020). https://doi.org/10.1016/j.optmat.2020.109957

Islam, T., Jani, R., Al Amin, S.M., Shorowordi, K.M., Nishat, S.S., Kabir, A., Taufique, M.F.N., Chowdhury, S., Banerjee, S., Ahmed, S.: Simulation studies to quantify the impacts of point defects: An investigation of $\mathrm{Cs}_{2} \mathrm{AgBiBr}_{6}$ perovskite solar devices utilizing $\mathrm{ZnO}$ and $\mathrm{Cu}_{2} \mathrm{O}$ as the charge transport layers. Comput. Mater. Sci. 184, 109865 (2020). https://doi.org/10.1016/j.commatsci.2020.109865

Jamal, S., Khan, Aimal Daud, Khan, Adnan Daud: High performance perovskite solar cell based on efficient materials for electron and hole transport layers. Optik 218, 164787 (2020). https://doi.org/10.1016/j.ijleo.2020.164787

Jamal, M.S., Shahahmadi, S.A., Wadi, M.A.A., Chelvanathan, P., Asim, N., Misran, H., Hossain, M.I., Amin, N., Sopian, K., Akhtaruzzaman, M.: Effect of defect density and energy level mismatch on the performance of perovskite solar cells by numerical simulation. Optik 182, 1204-1210 (2019). https://doi.org/10.1016/j.ijleo.2018.12.163

Jani, M.R., Islam, M.T., Al Amin, S.M., Sami, M.S.U., Shorowordi, K.M., Hossain, M.I., Chowdhury, S., Nishat, S.S., Ahmed, S.: Exploring solar cell performance of inorganic $\mathrm{Cs}_{2} \mathrm{TiBr}_{6}$ halide double perovskite: A numerical study. Superlattices Microstruct. 146, 106652 (2020). https://doi.org/10.1016/j.spmi.2020.106652

Jiang, X., Wang, F., Wei, Q., Li, H., Shang, Y., Zhou, W., Wang, C., Cheng, P., Chen, Q., Chen, L., Ning, Z.: Ultra-high open-circuit voltage of tin perovskite solar cells via an electron transporting layer design. Nat. commun. 11(1), 1-7 (2020). https://doi.org/10.1038/s4146720-15078-2

Keshavarz, M., Debroye, E., Ottesen, M., Martin, C., Zhang, H., Fron, E., Küchler, R., Steele, J.A., Bremholm, M., Van de Vondel, J., Wang, H. I., Bonn, M., Roeffaers, M.B.J., Wiedemann, S., Hofkens, J.: Tuning the structural and optoelectronic properties of $\mathrm{Cs}_{2} \mathrm{AgBiBr}_{6} \mathrm{double}$ perovskite single crystals through Alkali-Metal Substitution. Adv. Mater. 32(40), 2001878 (2020). https://doi.org/10.1002/adma.202001878

Kim, M., Ryu, S.U., Park, S.A., Choi, K., Kim, T., Chung, D., Park, T.: Organic Field-Effect Transistors: Donor-acceptor-conjugated polymer for high-performance organic field-effect transistors: a Progress report. Adv. Funct. Mater. 30(20), 2070130 (2020). https://doi.org/10.1002/adfm.201904545

Lee, J.-W., Park, N.-G.: Chemical approaches for stabilizing perovskite solar cells. Adv. Energy Mater. 10(1), 1903249 (2020). https://doi.org/10.1002/aenm.201903249

Liao, W., Zhao, D., Yu, Y., Grice, C.R., Wang, C., Cimaroli, A.J., Schulz, P., Meng, W., Zhu, K., Xiong, R.-G., Yan, Y.: Lead-free inverted planar formamidinium tin triiodide perovskite solar cells achieving power conversion efficiencies up to 6.22\%. Adv. Mater. 28(42), 9333-9340 (2016). https://doi.org/10.1002/adma.201602992

Li, P., Gao, W., Ran, C., Dong, H., Hou, X., Wu, Z.: Post-treatment engineering of Vacuum-Deposited Cs2 NaBil ${ }_{6}$ double perovskite film for enhanced photovoltaic performance. Phys. status solidi (a) 216(23), 1900567 (2019). https://doi.org/10.1002/pssa.201900567

Li, C., Song, Z., Chen, C., Xiao, C., Subedi, B., Harvey, S.P., Shrestha, N., Subedi, K.K., Chen, L., Liu, D., Li, Y., Kim, Y.-W., Jiang, C.-S., Heben, M.J., Zhao, D., Ellingson, R.J., Podraza, N.J., Al-Jassim, M., Yan, Y.: Low-bandgap mixed tin-lead iodide perovskites with reduced methylammonium for simultaneous enhancement of solar cell efficiency and stability. Nat. Energy 5(10), 768-776 (2020). https://doi.org/10.1038/s41560-020-00692-7

Li, H., Zhang, W.: Perovskite tandem solar cells: from fundamentals to commercial deployment. Chem. Rev. 120(18), 9835-9950 (2020). https://doi.org/10.1021/acs.chemrev.9b00780

Liu, M., Pasanen, H., Ali-Löytty, H., Hiltunen, A., Lahtonen, K., Qudsia, S., Smått, J.-H., Valden, M., Tkachenko, N.V., Vivo, P.: B-Site CoAlloying with Germanium Improves the Efficiency and Stability of All-Inorganic Tin-Based Perovskite Nanocrystal Solar Cells. Angew. Chem. 132(49), 22301-22309 (2020). https://doi.org/10.1002/ange.202008724

Liu, X., Wang, Y., Wu, T., He, X., Meng, X., Barbaud, J., Chen, H., Segawa, H., Yang, X., Han, L.: Efficient and stable tin perovskite solar cells enabled by amorphous-polycrystalline structure. Nat. commun. 11, 2678 (2020). https://doi.org/10.1038/s41467-020-16561-6

Longo, G., Mahesh, S., Buizza, L.R.V., Wright, A.D., Ramadan, A.J., Abdi-Jalebi, M., Nayak, P.K., Herz, L.M., Snaith, H.J.: Understanding the performance-limiting factors of $\mathrm{Cs}_{2} \mathrm{AgBiBr}_{6}$ double-perovskite solar cells. ACS Energy Lett. 5(7), 2200-2207 (2020). https://doi.org/10.1021/acsenergylett.0c01020

McClure, E.T., Ball, M.R., Windl, W., Woodward, P.M.: $\mathrm{Cs}_{2} \mathrm{AgBiX}_{6}(\mathrm{X}=\mathrm{Br}, \mathrm{Cl})$ : New visible light absorbing, lead-free halide perovskite semiconductors. Chem. Mater. 28(5), 1348-1354 (2016). https://doi.org/10.1021/acs.chemmater.5b04231

Mkhalid, I.A., Shawky, A.: Cu-supported $\mathrm{Cu}_{2} \mathrm{O}$ nanoparticles: Optimized photodeposition enhances the visible light photodestruction of atrazine. J. Alloys Compd. 853, 157040 (2021). https://doi.org/10.1016/j.jallcom.2020.157040

Minbashi, M., Ghobadi, A., Ehsani, M.H., Dizaji, H.R., Memarian, N.: Simulation of high efficiency SnS-based solar cells with SCAPS. Sol. Energy 176, 520-525 (2018). https://doi.org/10.1016/j.solener.2018.10.058

Minemoto, T., Kawano, Y., Nishimura, T., Chantana, J.: Numerical reproduction of a perovskite solar cell by device simulation considering band gap grading. Opt. Mater. 92, 60-66 (2019). https://doi.org/10.1016/j.optmat.2019.03.048

Minemoto, T., Murata, M.: Theoretical analysis on effect of band offsets in perovskite solar cells. Sol. Energy Mater. Sol. Cells 133, 8-14 (2015). https://doi.org/10.1016/j.solmat.2014.10.036 
Mohseni, H.R., Dehghanipour, M., Dehghan, N., Tamaddon, F., Ahmadi, M., Sabet, M., Behjat, A.: Enhancement of the photovoltaic performance and the stability of perovskite solar cells via the modification of electron transport layers with reduced graphene oxide/polyaniline composite. Sol. Energy 213, 59-66 (2021). https://doi.org/10.1016/j.solener.2020.11.017

Nithya, K.S., Sudheer, K.S.: Device modelling of non-fullerene organic solar cell with inorganic Cul hole transport layer using SCAPS 1D. Optik 217, 164790 (2020). https://doi.org/10.1016/j.ijleo.2020.164790

Noel, N.K., Stranks, S.D., Abate, A., Wehrenfennig, C., Guarnera, S., Haghighirad, A.-A., Sadhanala, A., Eperon, G.E., Pathak, S.K., Johnston, M.B., Petrozza, A., Herz, L.M., Snaith, H.J.: Lead-free organic-inorganic tin halide perovskites for photovoltaic applications. Energy Environ. Sci. 7(9), 3061-3068 (2014). https://doi.org/10.1039/c4ee01076k

Ogomi, Y., Morita, A., Tsukamoto, S., Saitho, T., Fujikawa, N., Shen, Q., Toyoda, T., Yoshino, K., Pandey, S.S., Ma, T., Hayase, S.: $\mathrm{CH}_{3} \mathrm{NH}_{3} \mathrm{SnxPb}(1-\mathrm{x}) \quad \mathrm{l}_{3}$ perovskite solar cells covering up to $1060 \mathrm{~nm}$. J. Phys. Chem. Lett. 5(6), 1004-1011 (2014). https://doi.org/10.1021/jz5002117

Poli, I., Kim, G.-W., Wong, E.L., Treglia, A., Folpini, G., Petrozza, A.: High External Photoluminescence Quantum Yield in Tin Halide Perovskite Thin Films. ACS energy lett. 6(2), 609-611 (2021). https://doi.org/10.1021/acsenergylett.0c02612

Rai, S., Pandey, B.K., Dwivedi, D.K.: Modeling of highly efficient and low cost $\mathrm{CH}_{3} \mathrm{NH}_{3} \mathrm{~Pb}\left(\mathrm{I}_{1-\mathrm{x}} \mathrm{Cl}_{\mathrm{x}}\right)_{3}$ based perovskite solar cell by numerical simulation. Opt. Mater. 100, 109631 (2020). https://doi.org/10.1016/j.optmat.2019.109631

Savory, C.N., Walsh, A., Scanlon, D.O.: Can Pb-free Halide Double Perovskites Support High-efficiency Solar Cells? ACS energy lett. 1(5), 949955 (2016). https://doi.org/10.1021/acsenergylett.6b00471

Shi, Z., Guo, J., Chen, Y., Li, Q., Pan, Y., Zhang, H., Xia, Y., Huang, W.: Lead-Free Organic-Inorganic Hybrid Perovskites for Photovoltaic Applications: Recent Advances and Perspectives. Adv. Mater. 29(16), 1605005 (2017). https://doi.org/10.1002/adma.201605005

Shikoh, A.S., Paek, S., Polyakov, A.Y., Smirnov, N.B., Shchemerov, I.V., Saranin, D.S., Didenko, S.I., Ahmad, Z., Touati, F., Nazeeruddin, M.K.: Assessing mobile ions contributions to admittance spectra and current-voltage characteristics of 3D and 2D/3D perovskite solar cells. Sol. Energy Mater. Sol. Cells 215, 110670 (2020). https://doi.org/10.1016/j.solmat.2020.110670

Singh, A.N., Kajal, S., Kim, J., Jana, A., Kim, J.Y., Kim, K.S.: Interface Engineering Driven Stabilization of Halide Perovskites against Moisture, Heat, and Light for Optoelectronic Applications. Adv. Energy Mater. 10(30), 2000768 (2020). https://doi.org/ 10.1002/ aenm.202000768

Slavney, A.H., Hu, T., Lindenberg, A.M., Karunadasa, H.I.: Bismuth-Halide Double Perovskite with Long Carrier Recombination Lifetime for Photovoltaic Applications. J. Am. Chem. Soc. 138(7), 2138-2141 (2016). https://doi.org/10.1021/jacs.5b13294

Slavney, A.H., Leppert, L., Bartesaghi, D., Gold-Parker, A., Toney, M.F., Savenije, T.J., Neaton, J.B., Karunadasa, H.I.: Defect-Induced BandEdge Reconstruction of a Bismuth-Halide Double Perovskite for Visible-Light Absorption. J. Am. Chem. Soc. 139(14), 5015-5018 (2017). https://doi.org/10.1021/jacs.7b01629

Soto-Montero, T., Flores-Díaz, N., Molina, D., Soto-Navarro, A., Lizano-Villalobos, A., Camacho, C., Hagfeldt, A., Pineda, L.W.: Dopant-Free Hole-Transport Materials with Germanium Compounds Bearing Pseudohalide and Chalcogenide Moieties for Perovskite Solar Cells. Inorg. Chem. 59(20), 15154-15166 (2020). https://doi.org/10.1021/acs.inorgchem.0c02120

Tan, X., Liu, X., Liu, Z., Sun, B., Li, J., Xi, S., Shi, T., Tang, Z., Liao, G.: Enhancing the optical, morphological and electronic properties of the solution-processed $\mathrm{CsPbIBr}_{2}$ films by Li doping for efficient carbon-based perovskite solar cells. Appl. Surf. Sci. 499, 143990 (2020). https://doi.org/10.1016/j.apsusc.2019.143990

Teimouri, R., Heydari, Z., Ghaziani, M.P., Madani, M., Abdy, H., Kolahdouz, M., Asl-Soleimani, E.: Synthesizing Li doped TiO 2 electron transport layers for highly efficient planar perovskite solar cell. Superlattices Microstruct. 145, 106627 (2020). https://doi.org/10.1016/j.spmi.2020.106627

Usiobo, O.J., Kanda, H., Gratia, P., Zimmermann, I., Wirtz, T., Nazeeruddin, M.K., Audinot, J.-N.: Nanoscale Mass-Spectrometry Imaging of Grain Boundaries in Perovskite Semiconductors. J. Phys. Chem. C 124(42), 23230-23236 (2020). https://doi.org/10.1021/acs.jpcc.0c07464

Wang, B., Yang, J., Lu, L., Xiao, W., Wu, H., Xiong, S., Tang, J., Duan, C., Bao, Q.: Interface Engineering of Air-Stable n-Doping Fullerene- Modified $\mathrm{TiO}_{2}$ Electron Transport Layer for Highly Efficient and Stable Perovskite Solar Cells. Adv. Mater. Interfaces 7(6), 1901964 (2020). https://doi.org/10.1002/admi.201901964

Wei, F., Deng, Z., Sun, S., Zhang, F., Evans, D.M., Kieslich, G., Tominaka, S., Carpenter, M.A, Zhang J., Bristowe, P.D., Cheetham, A.K.: The Synthesis and Properties of a Lead-Free Hybrid Double Perovskite: $\left(\mathrm{CH}_{3} \mathrm{NH}_{3}\right)_{2} \mathrm{AgBiBr} 6$. Chem. Mater. 29(3), 1089-1094 (2017). https://doi.org/10.1021/acs.chemmater.6b03944

Wu, C., Zhang, Q., Liu, Y., Luo, W., Guo, X., Huang, Z., Ting, H., Sun, W., Zhong, X., Wei, S., Wang, S., Chen, Z., Xiao, L.: The Dawn of LeadFree Perovskite Solar Cell: Highly Stable Double Perovskite $\mathrm{Cs}_{2} \mathrm{AgBiBr}_{6}$ Film. Adv. Sci. 5(3), 1700759 (2018). https://doi.org/ 10.1002/ advs.201700759

Xi, J., Wu, Z., Jiao, B., Dong, H., Ran, C., Piao, C., Lei, T., Song, T.-B., Ke, W., Yokoyama, T., Hou, X., Kanatzidis, M.G.: Multichannel Interdiffusion Driven $\mathrm{FASnl}_{3}$ Film Formation Using Aqueous Hybrid Salt/Polymer Solutions toward Flexible Lead-Free Perovskite Solar Cells. Adv. Mater. 29(23), 1606964 (2017). https://doi.org/10.1002/adma.201606964

Xu, K.: Development of tin-based perovskite materials for solar cell applications: A minireview. Instrum. Sci. Technol. 49(1), 91-105 (2021). https://doi.org/10.1080/10739149.2020.1785891

Xu, J., Saklatvala, R., Mittal, S., Deshmukh, S., Procopio, A.: Recent Progress of potentiating immune checkpoint blockade with external stimuli-An industry perspective. Adv. Sci. 7(8), 1903394 (2020). https://doi.org/10.1002/advs.201903394

Xu, Z., Teo, S.H., Gao, L., Guo, Z., Kamata, Y., Hayase, S., Ma, T.: La-doped $\mathrm{SnO}_{2}$ as ETL for efficient planar-structure hybrid perovskite solar cells. Org. Electron. 73, 62-68 (2019). https://doi.org/10.1016/j.orgel.2019.03.053

Yang, X., Chen, Y., Liu, P., Xiang, H., Wang, W., Ran, R., Zhou, W., Shao, Z.: Simultaneous Power Conversion Efficiency and Stability Enhancement of $\mathrm{Cs}_{2} \mathrm{AgBiBr}_{6}$ Lead-Free Inorganic Perovskite Solar Cell through Adopting a Multifunctional Dye Interlayer. Adv. Funct. Mater. 30(23), 2001557 (2020). https://doi.org/10.1002/adfm.202001557

Yang, Z., Dou, J., Kou, S., Dang, J., Ji, Y., Yang, G., Wu, W.-Q., Kuang, D.-B., Wang, M.: Multifunctional Phosphorus-Containing Lewis Acid and Base Passivation Enabling Efficient and Moisture-Stable Perovskite Solar Cells. Adv. Funct. Mater. 30(15), 1910710 (2020). https://doi.org/ 10.1002/adfm.201910710

Zhang, H., Dun, G., Feng, Q., Zhao, R., Liang, R., Gao, Z., Hirtz, T., Chen, M., Geng, X., Liu, M., Huang, Y., Zheng, X., Qin, K., Tan, X., Wang, X., Xie, D., Yang, Y., Tian, H., Zhou, Y., Padture, N., Wang, X., Hong, J., Ren, T.-L.: Encapsulated X-ray detector enabled by all-inorganic lead-free perovskite film with high sensitivity and low detection limit. IEEE Trans. Electron Devices 67(8), 3191-3198 (2020). https://doi.org/10.1109/ted.2020.2998763 
Zhang, F., Zhu, K.: Additive engineering for efficient and stable perovskite solar cells. Adv. Energy Mater. 10(13), 1902579 (2020). https://doi.org/10.1002/aenm.201902579

Zhao, P., Lin, Z., Wang, J., Yue, M., Su, J., Zhang, J., Chang, J., Hao, Y.: Numerical Simulation of Planar Heterojunction Perovskite Solar Cells Based on $\mathrm{SnO}_{2}$ Electron Transport Layer. ACS Appl. Energy Mater. 2(6), 4504-4512 (2019). https://doi.org/10.1021/acsaem.9b00755

Zhao, X.-G., Yang, J.-H., Fu, Y., Yang, D., Xu, Q., Yu, L., Wei, S.-H., Zhang, L.: Design of Lead-free Inorganic Halide Perovskites for Solar Cells via Cation-transmutation. J. Am. Chem. Soc. 139(7), 2630-2638 (2017). https://doi.org/10.1021/jacs.6b09645

Zhu, L., Liu, D., Wang, J., Wang, N.: Large Organic Cations in Quasi-2D Perovskites for High-Performance Light-Emitting Diodes. J. Phys. Chem. Lett. 11(20), 8502-8510 (2020). https://doi.org/10.1021/acs.jpclett.0c02476

Zuo, F., Williams, S.T., Liang, P.-W., Chueh, C.-C., Liao, C.-Y., Jen, A.K.-Y.: Binary-Metal Perovskites Toward High-Performance PlanarHeterojunction Hybrid Solar Cells. Adv. Mater. 26(37), 6454-6460 (2014). https://doi.org/10.1002/adma.201401641 
Figures

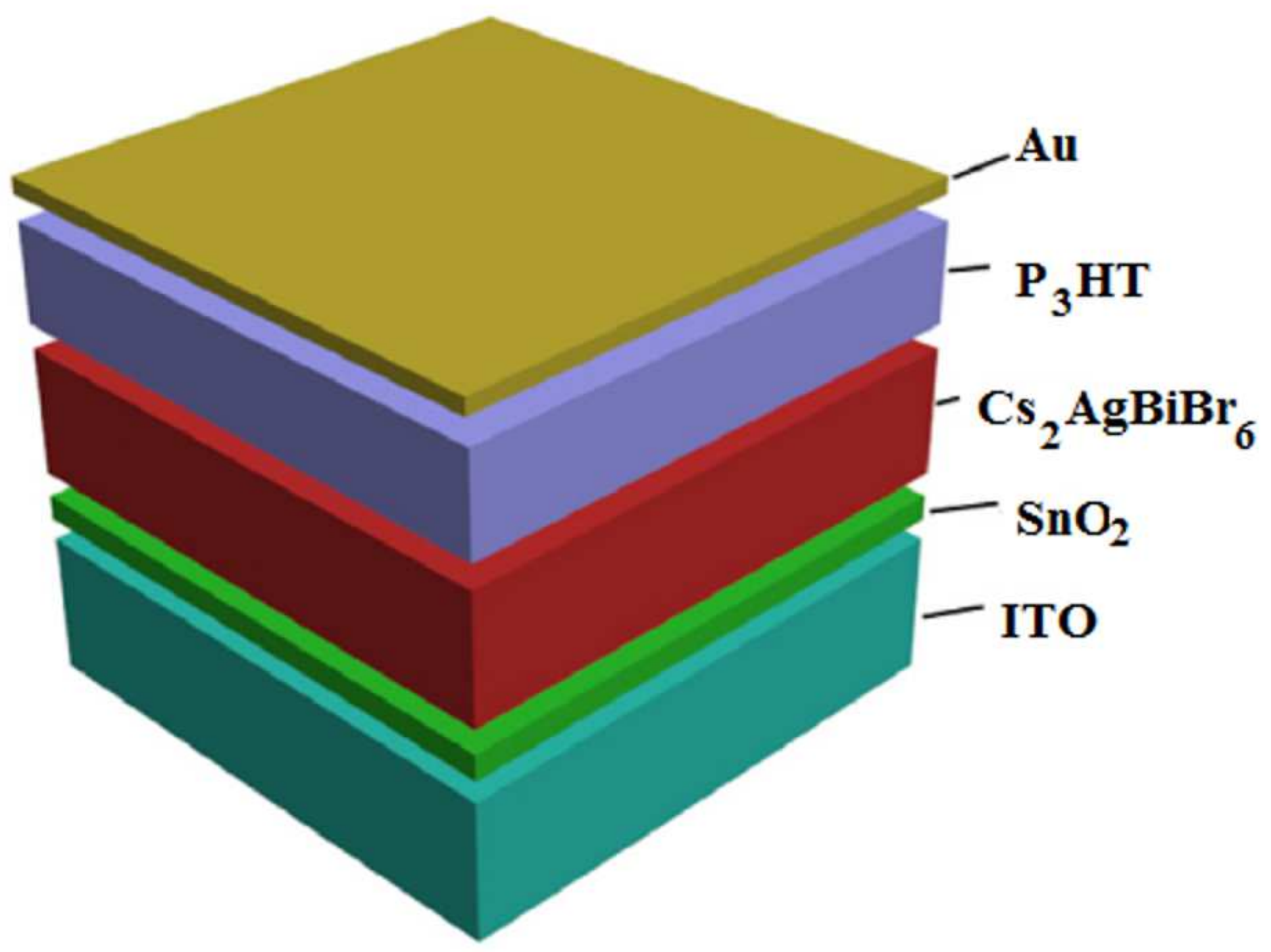

Figure 1

Device multilayer structure, ITO/SnO2/Cs2AgBiBr6/P3HT/Au, used in solar cells 
(a)

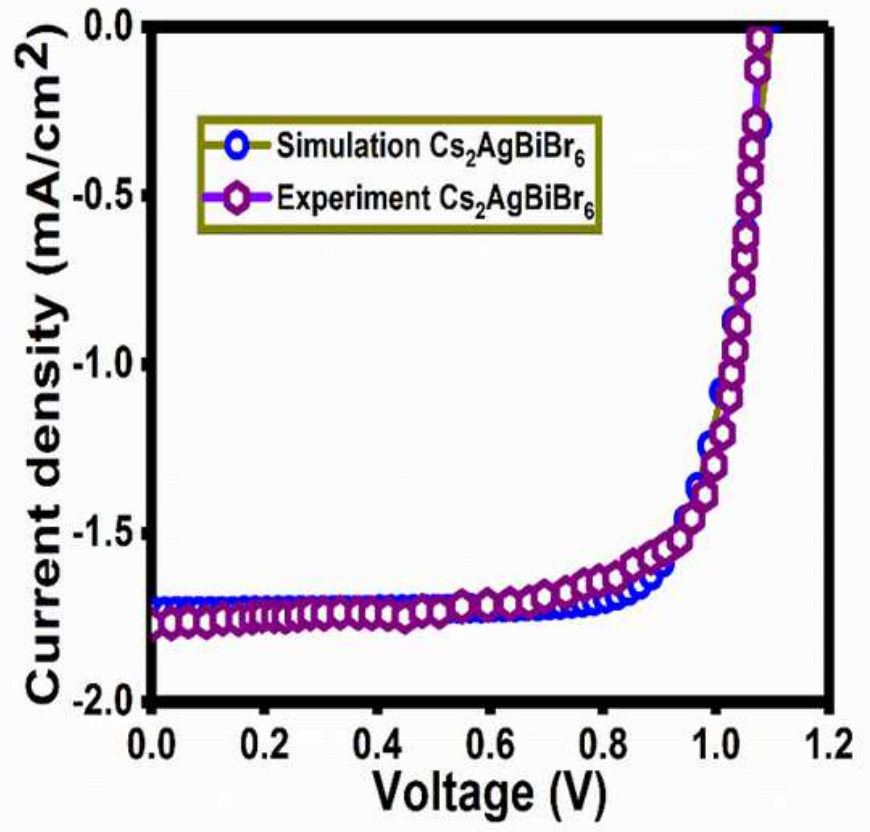

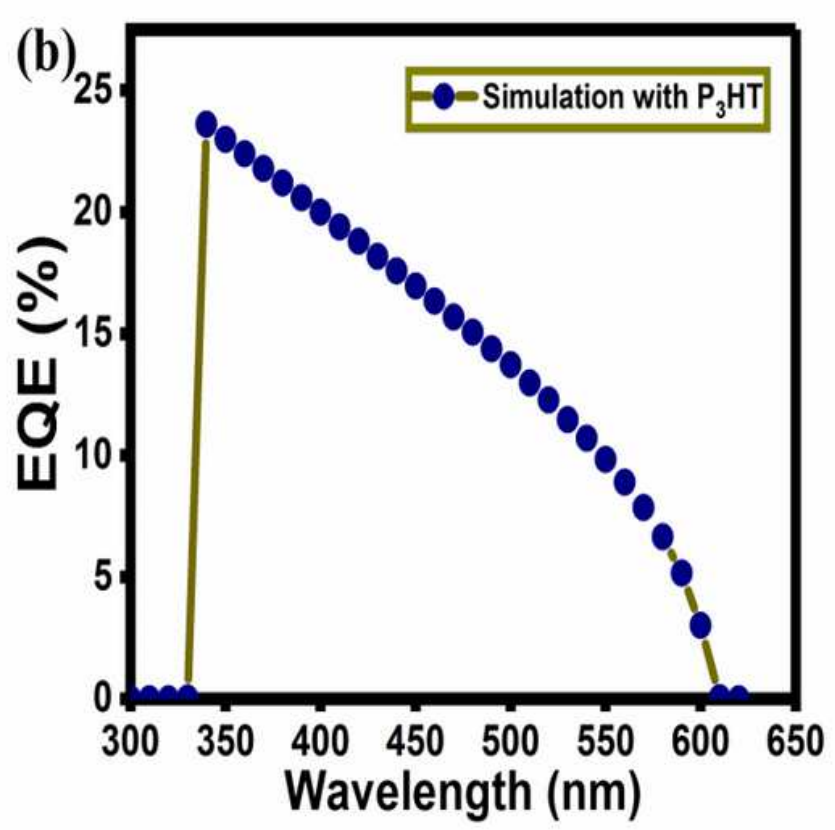

Figure 2

a Comparison of our simulation and experimental results of current density-voltage curves. b Calculated external quantum efficiency of the double perovskite solar cell, for ITO/SnO2/Cs2AgBiBr6/P3HT/Au cell (Wu et al. 2018)
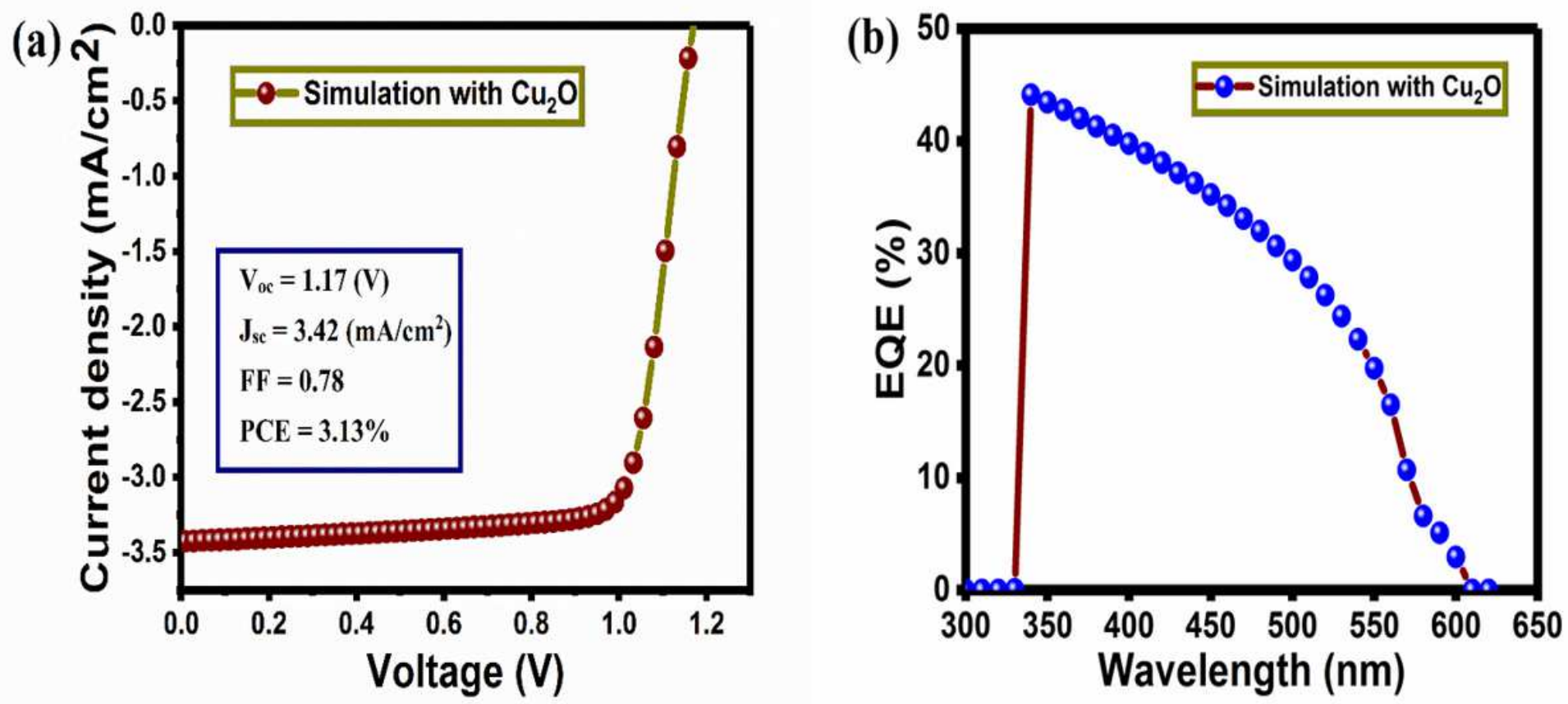

Figure 3

a The current density-voltage curve, and $b$ the computed external quantum efficiency, for ITO/SnO2/Cs2AgBiBr6/Cu2O/Au cell 

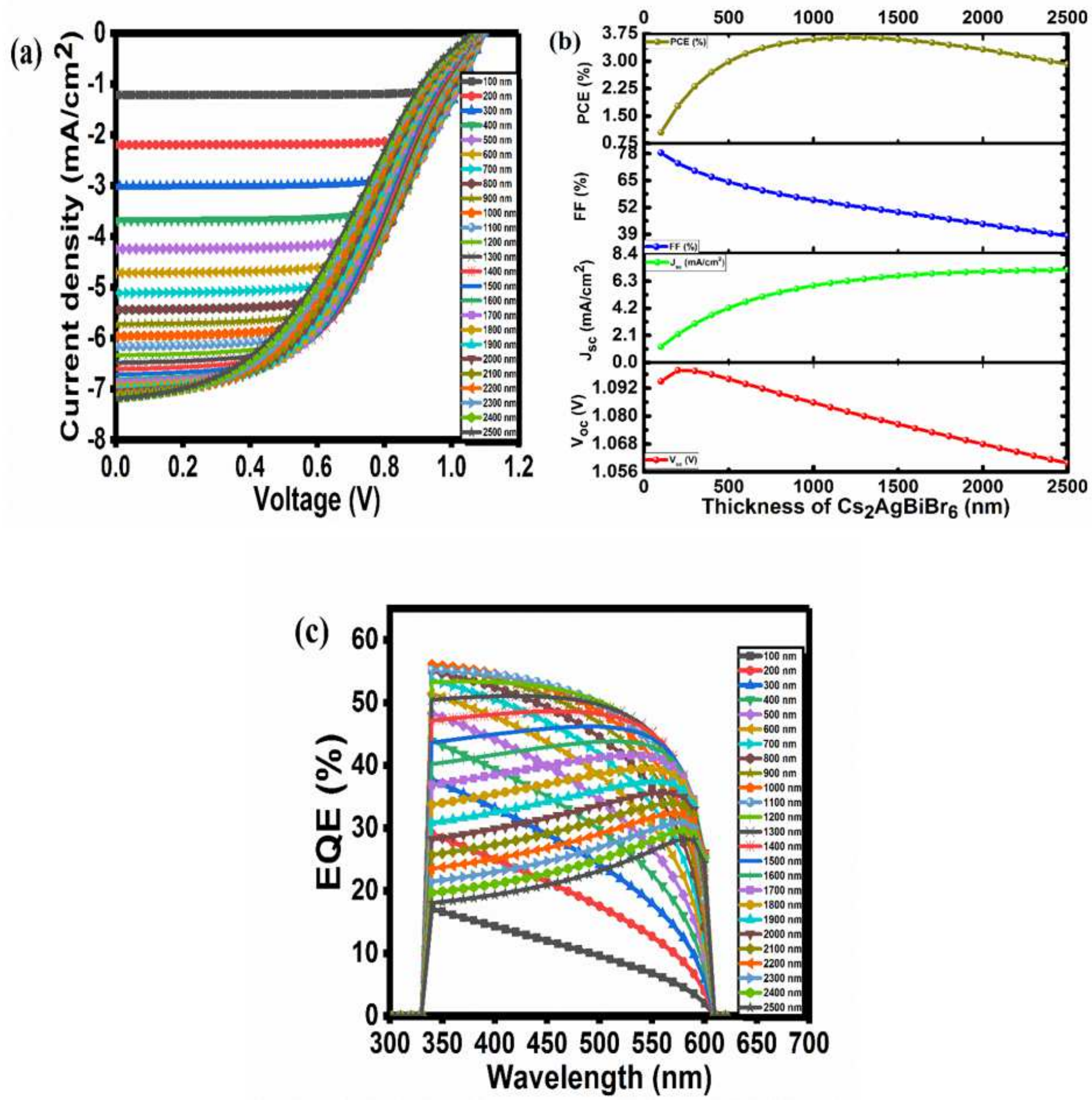

Figure 4

a Current density-voltage curves for different thicknesses of Cs2AgBiBr6. b The performance parameters of Voc, Jsc, FF and efficiency of the device as a function of Cs2AgBiBr6 thicknesses. c The external quantum efficiency for various thicknesses of Cs2AgBiBr6 

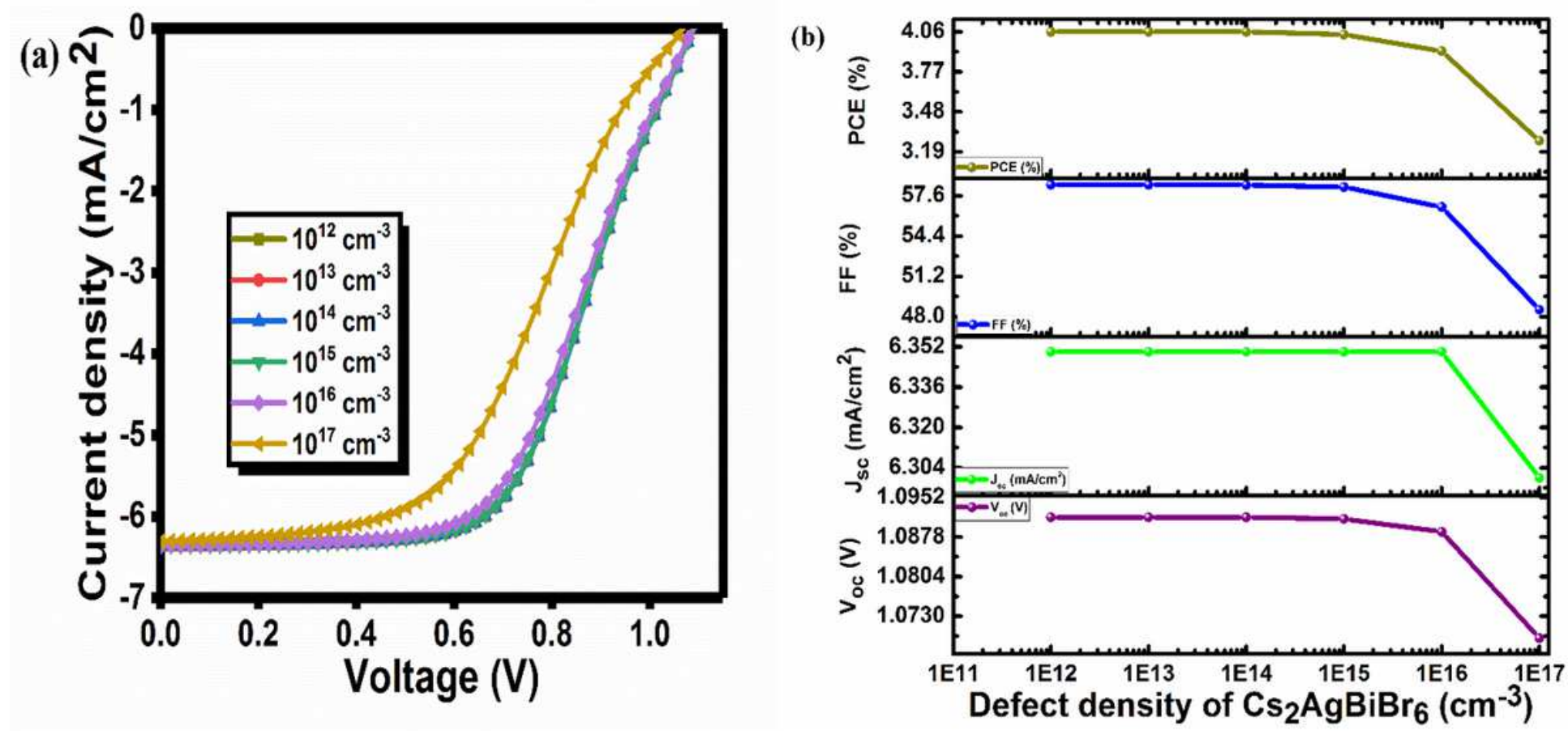

Figure 5

a The current density- voltage curves for various defect density ( $\mathrm{Nt}$ ) of device of Cs2AgBiBr6 changing from 1012 to $1017 \mathrm{~cm}-3$. b The performance parameters of Voc, Jsc, FF, and efficiency against defect density (Nt) of device varying from 1012 to $1017 \mathrm{~cm}-3$

(a)

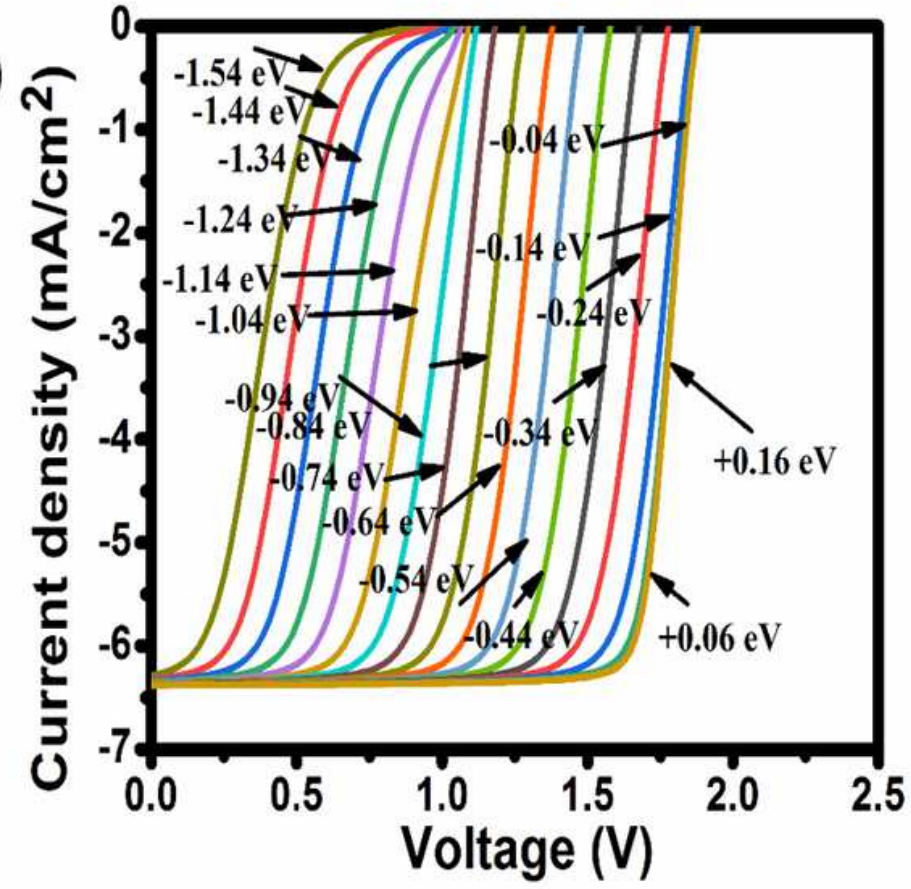

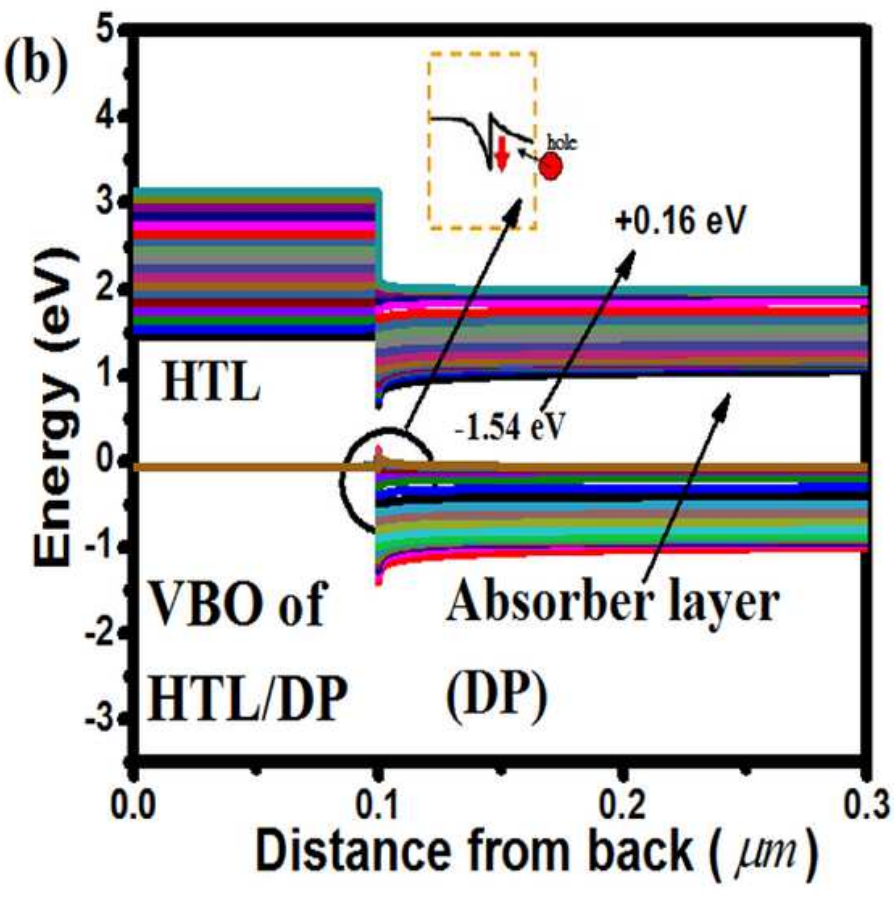

Figure 6

a The current density-voltage curves for VBO of $\mathrm{P} 3 \mathrm{HT} / \mathrm{Cs} 2 \mathrm{AgBiBr} 6$ changing from -1.54 to $+0.16 \mathrm{eV}$. b The energy band diagrams for VBO of $\mathrm{P} 3 \mathrm{HT} / \mathrm{Cs} 2 \mathrm{AgBiBr6}$ varying from -1.54 to $+0.16 \mathrm{eV}$ 

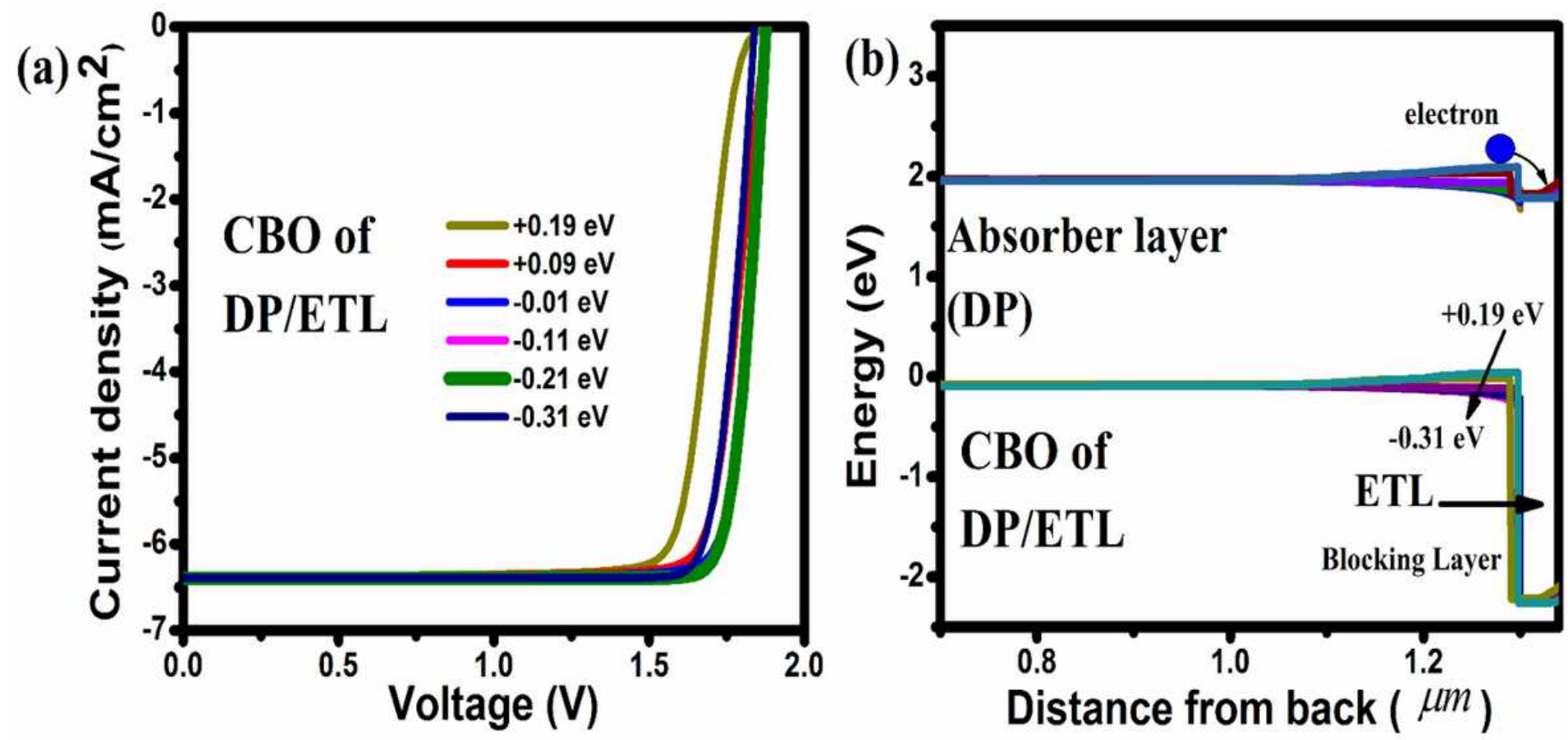

Figure 7

a The current density-voltage curves for $\mathrm{CBO}$ of $\mathrm{Cs} 2 \mathrm{AgBiBr} 6 / \mathrm{SnO} 2$ changing from +0.19 to $-0.31 \mathrm{eV}$. $\mathrm{b}$ The energy band diagrams for $\mathrm{CBO}$ of $\mathrm{Cs} 2 \mathrm{AgBiBr6} / \mathrm{SnO} 2$ changing from +0.19 to $-0.31 \mathrm{eV}$

(a)

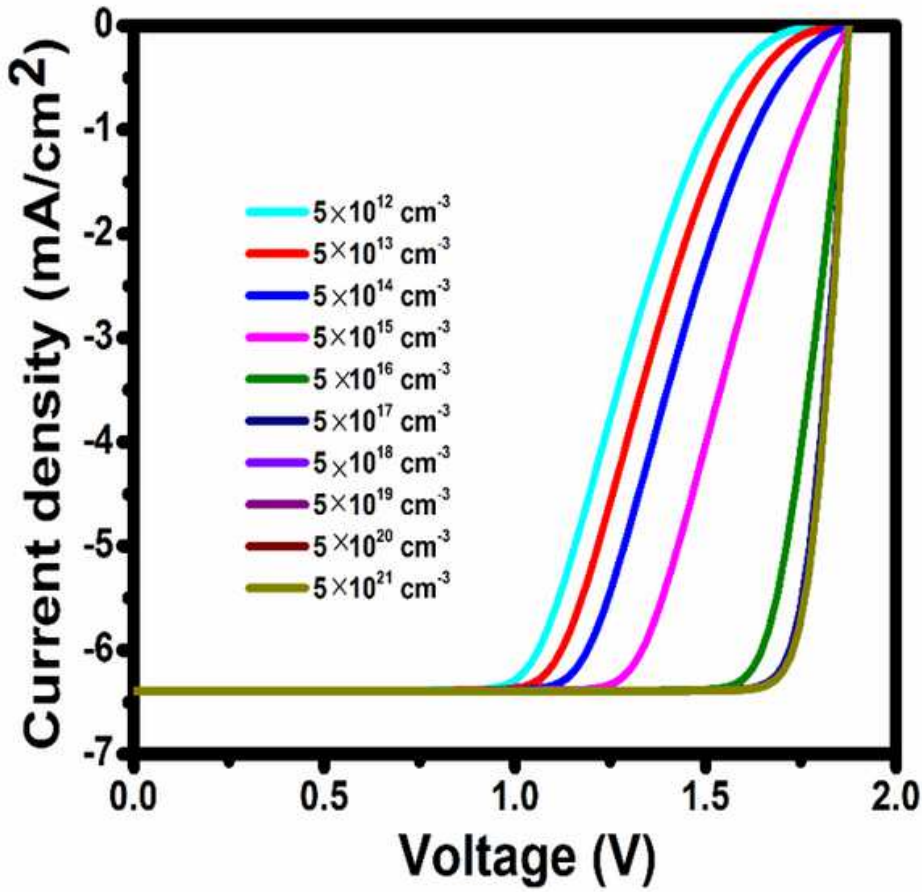

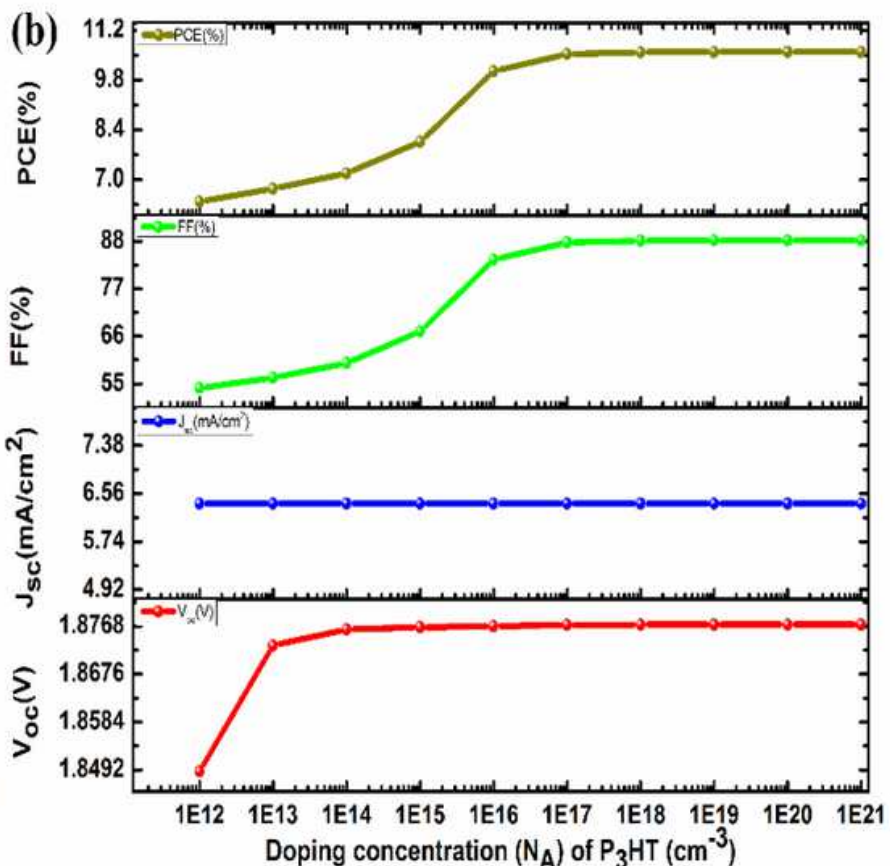

Figure 8

a The current density-voltage curves, and b the performance parameters of Voc, Jsc, FF and efficiency for various doping concentration, NA, of P3HT changing from $5 \times 10^{\wedge} 12$ to $5 \times 10^{\wedge} 21 \mathrm{~cm}^{\wedge}-3$ 

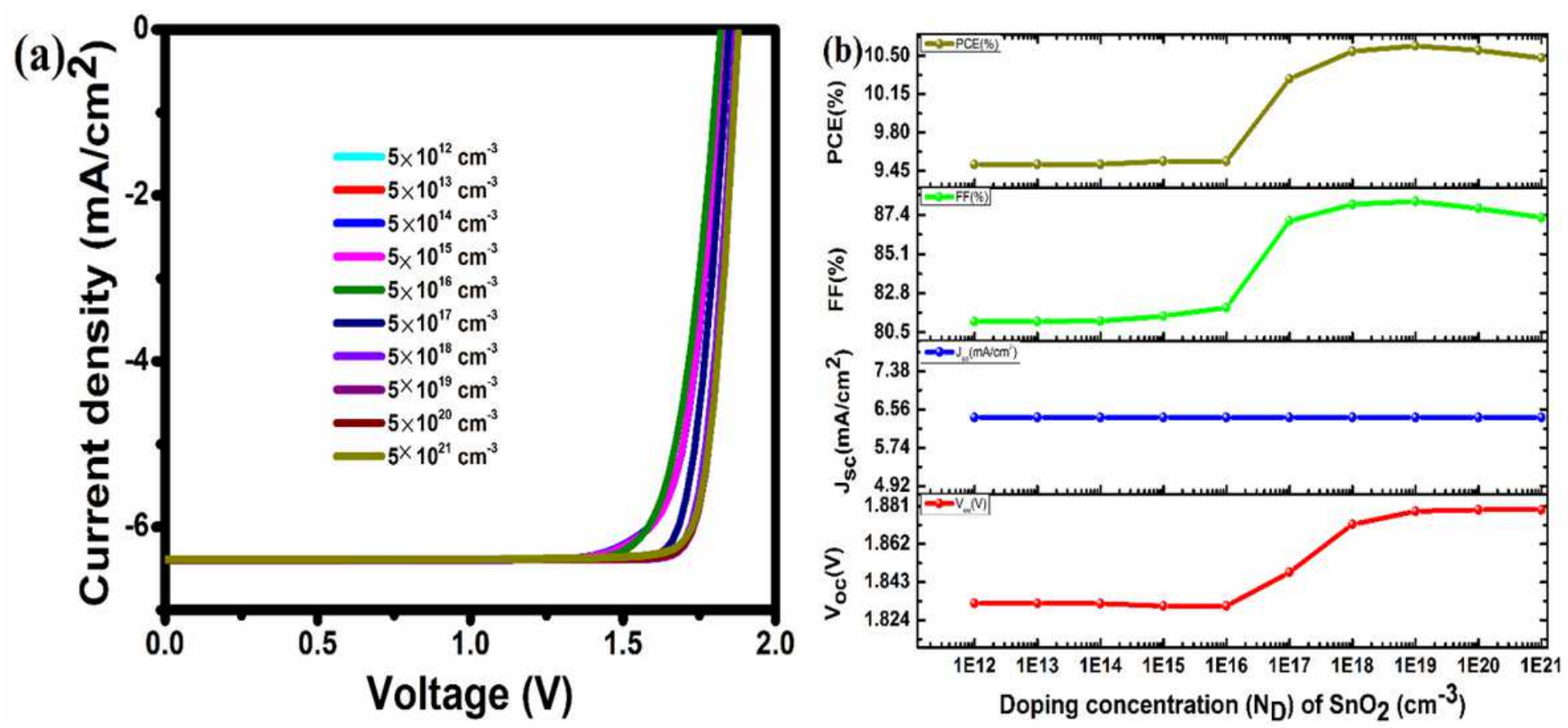

Figure 9

a The current density-voltage curves, and b the performance parameters of Voc, Jsc, FF and efficiency for different doping concentration, ND, of SnO2 changing from $5 \times 10^{\wedge} 12$ to $5 \times 10^{\wedge} 21 \mathrm{~cm}^{\wedge}-3$
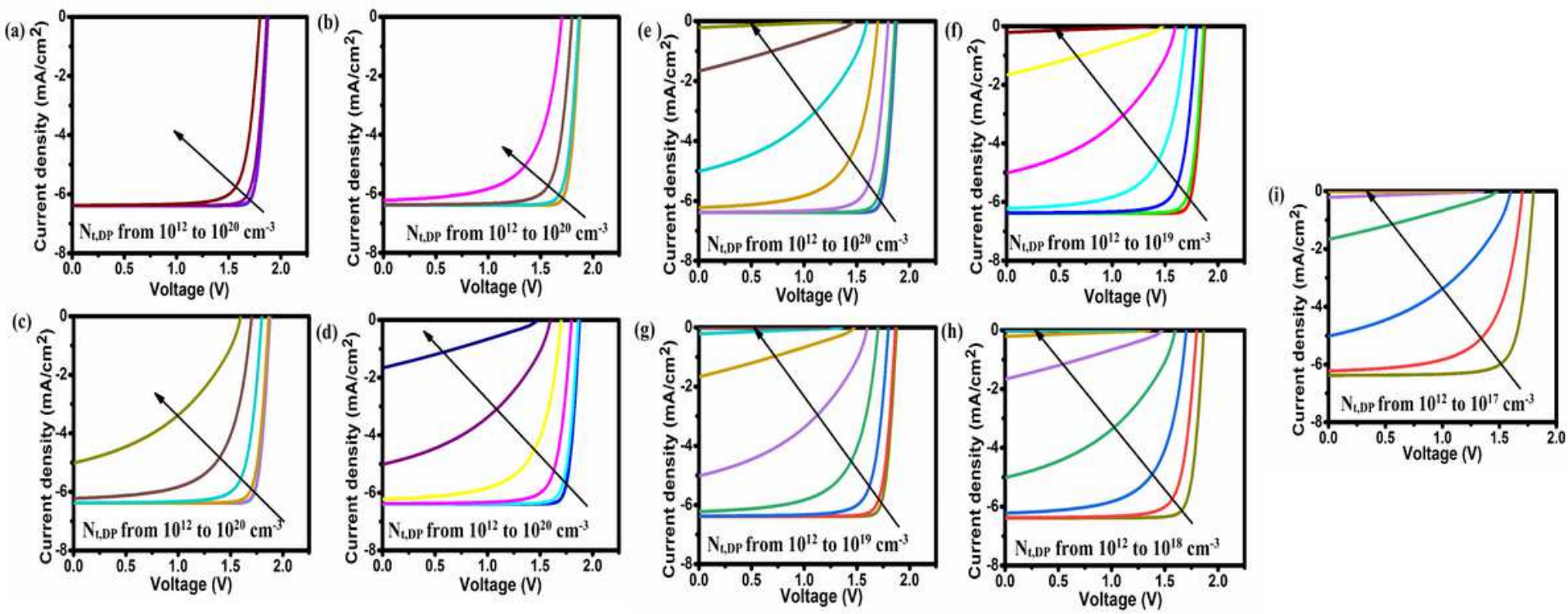

Figure 10

The current density-voltage curves... please see manuscript .pdf for full caption 

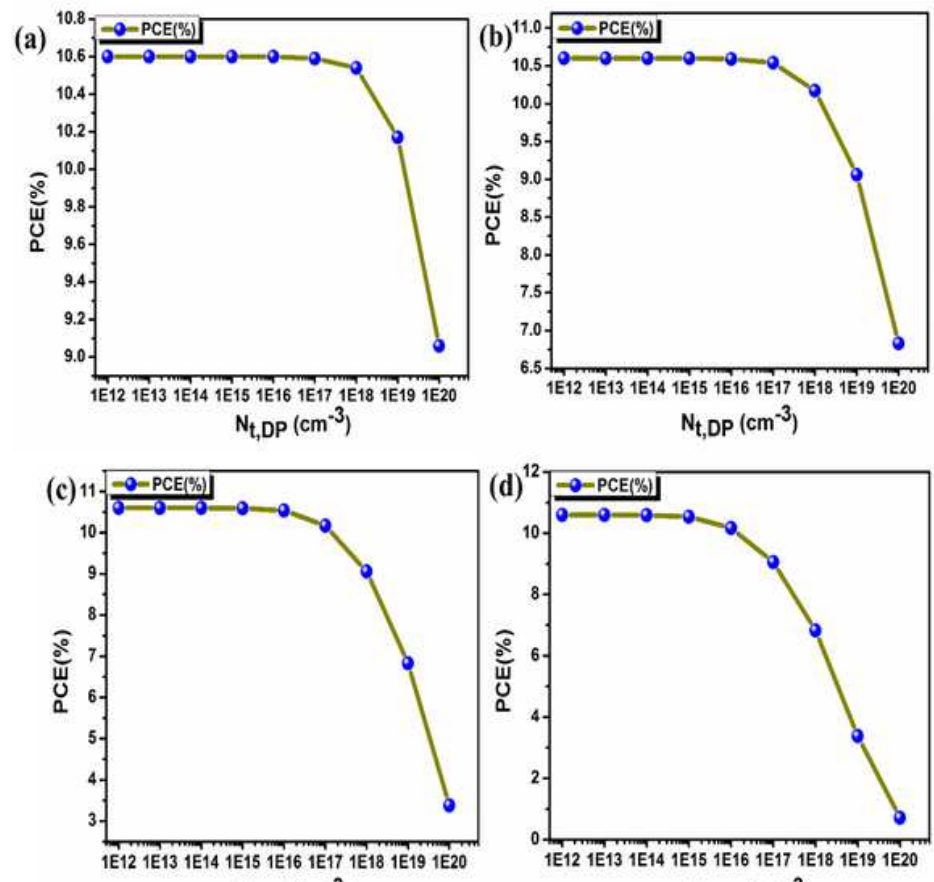

$\mathrm{N}_{\mathrm{t}, \mathrm{DP}}\left(\mathrm{cm}^{-3}\right)$

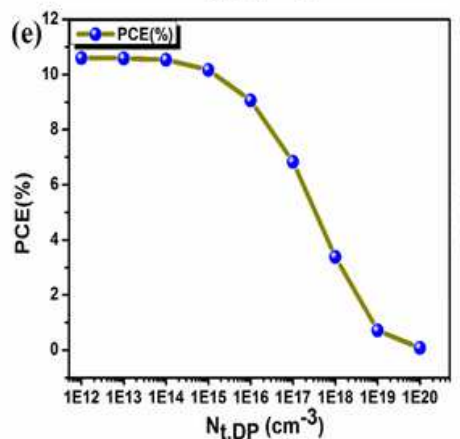

$\mathrm{N}_{\mathrm{t}, \mathrm{DP}}\left(\mathrm{cm}^{-3}\right)$
$\mathrm{N}_{\mathrm{t}, \mathrm{DP}}\left(\mathrm{cm}^{-3}\right)$

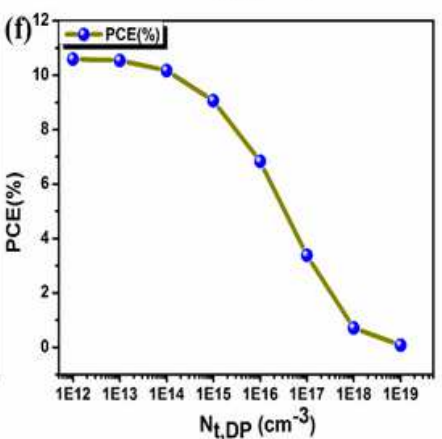

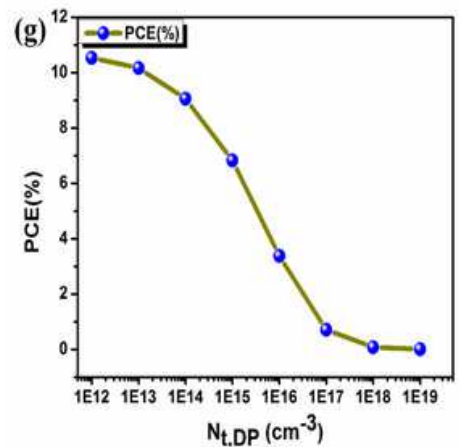
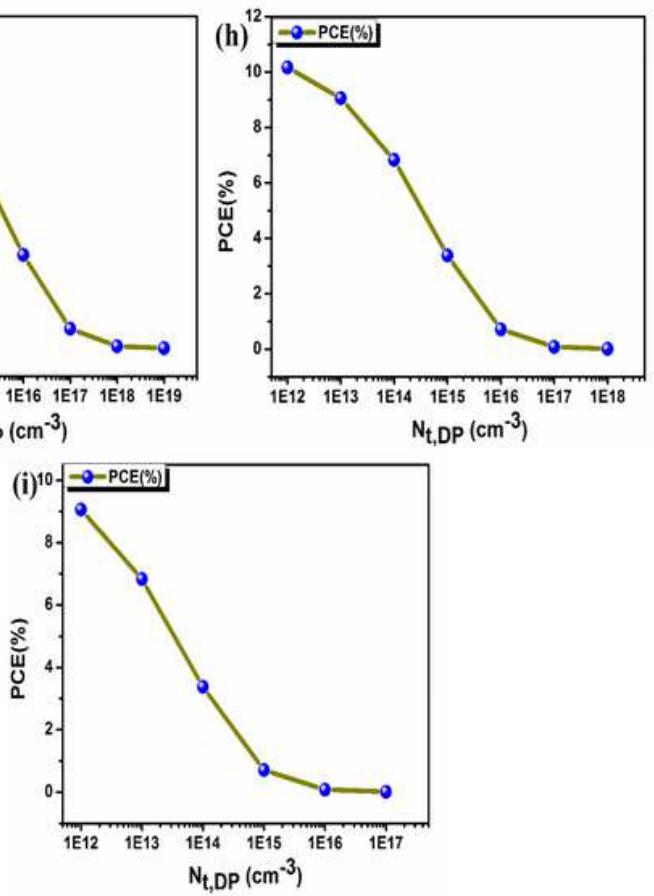

\section{Figure 11}

The PCE of solar cell against defect density of double perovskite for... please see manuscript .pdf for full caption 

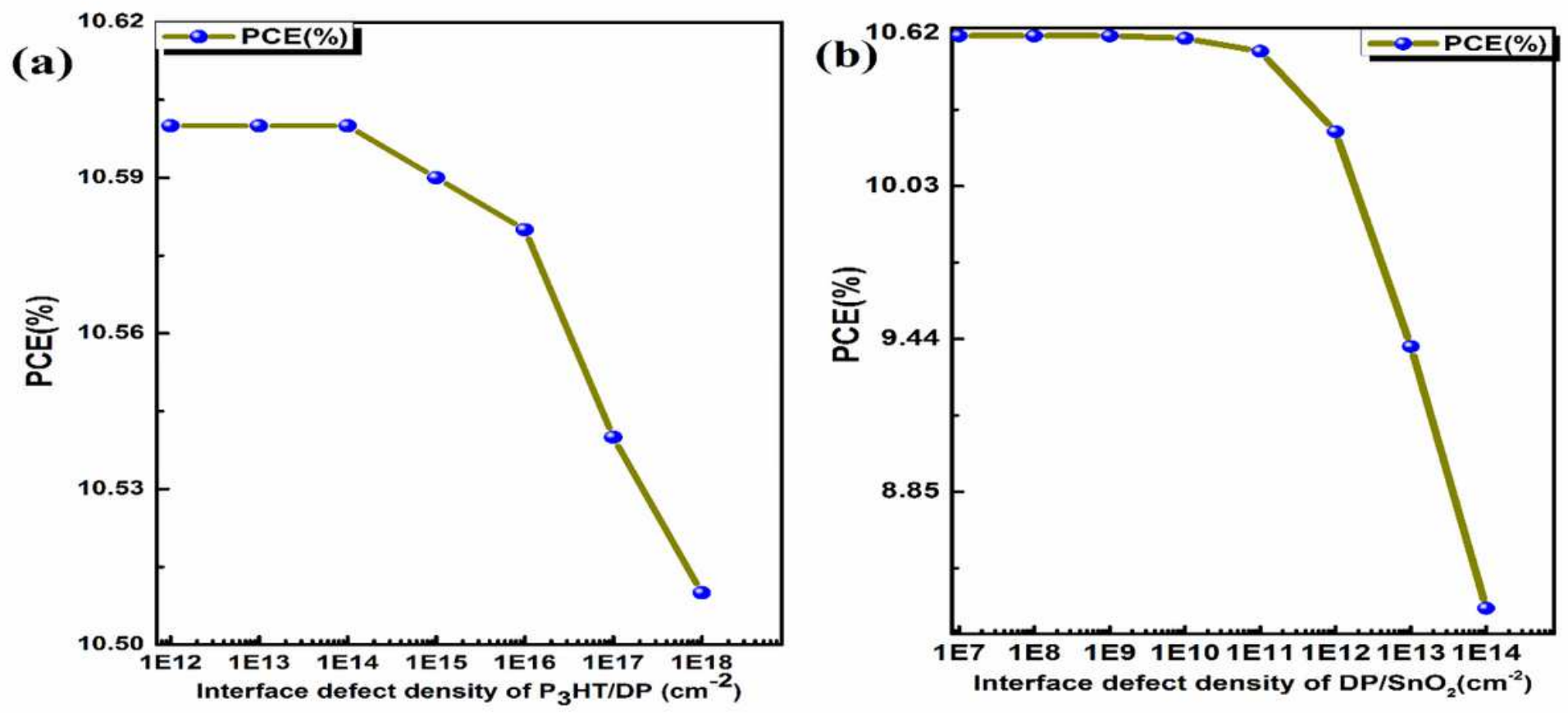

Figure 12

12 a PCE against interface defect density of P3HT/Cs2AgBiBr6 changing from 1012 to $1018 \mathrm{~cm}-2$. b PCE against interface defect density of Cs2AgBiBr6/SnO2 varying from 107 to $1014 \mathrm{~cm}-2$
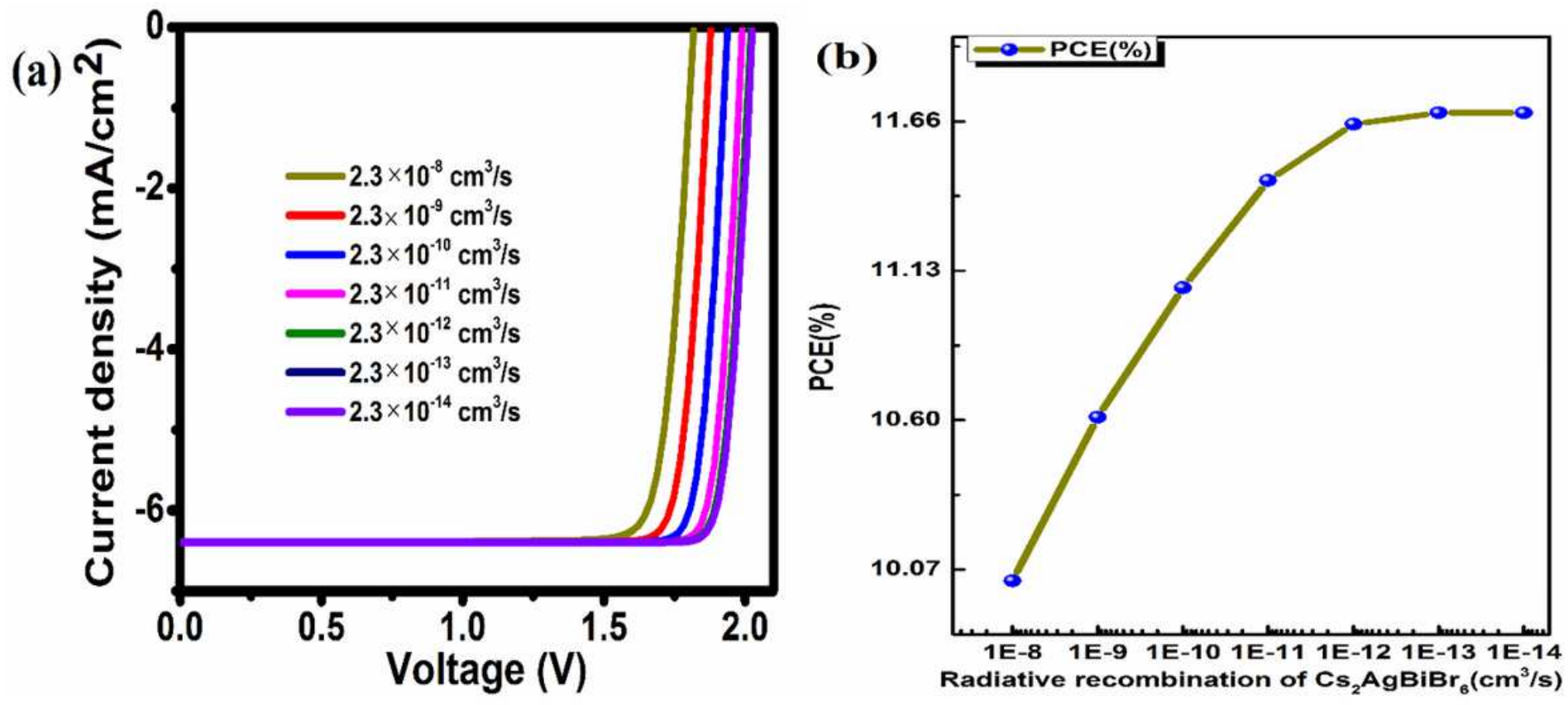

Figure 13

13 a The current density-voltage curves for radiative recombination of Cs2AgBiBr6 , b PCE against radiative recombination of $\mathrm{Cs} 2 \mathrm{AgBiBr6} \ldots$... please see manuscript .pdf for full caption 
(a)

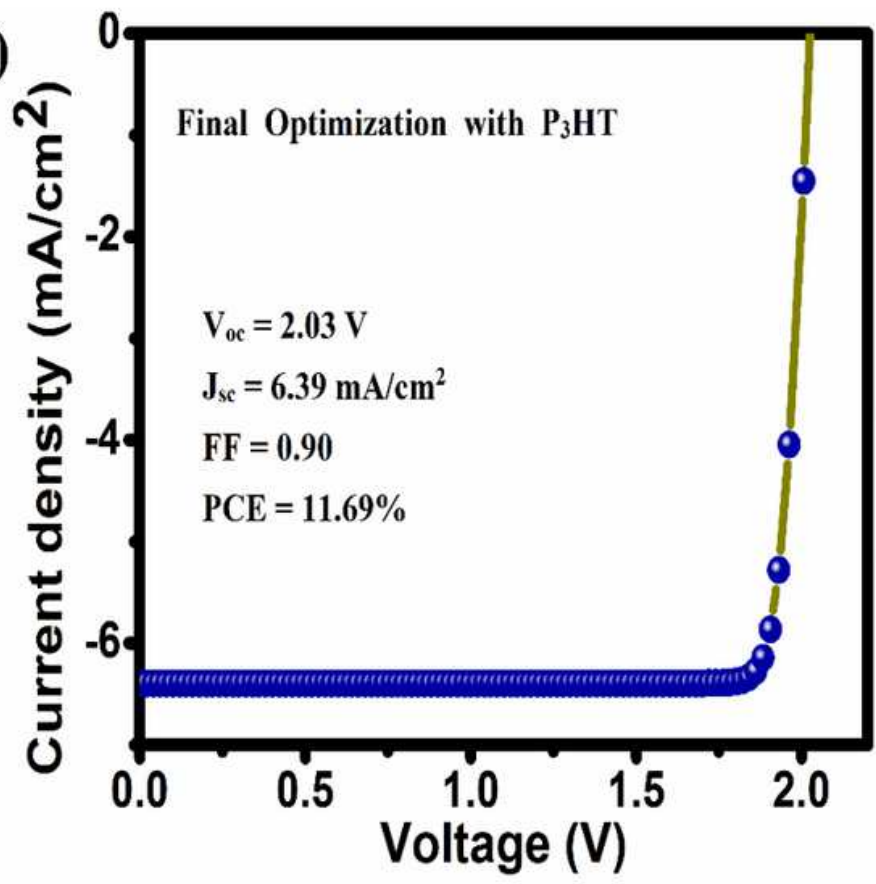

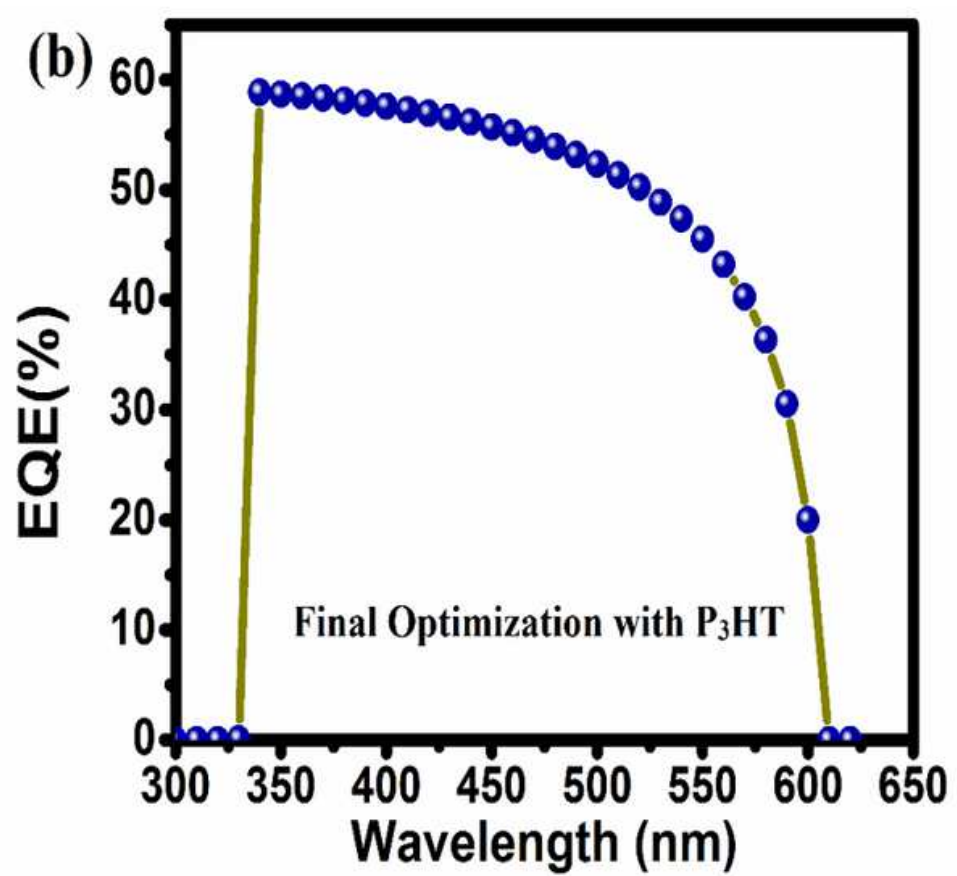

Figure 14

a The current density-voltage curve, and $b$ the calculated external quantum efficiency for ITO/SnO2/Cs2AgBiBr6/P3HT/Au cell, after doing all optimization using SCAPS
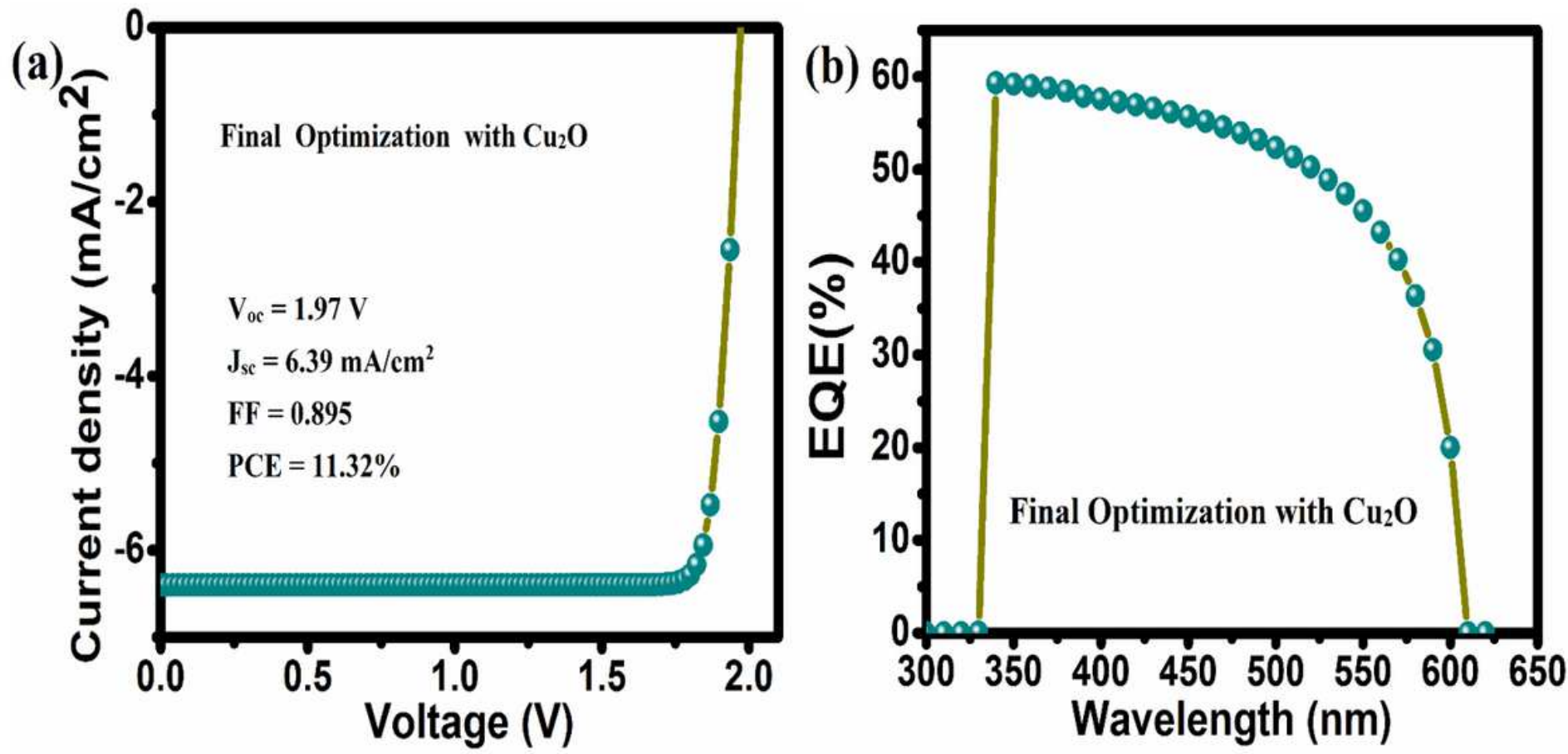

Figure 15

a The current density-voltage curve, and $b$ the computed external quantum efficiency for ITO/SnO2/Cs2AgBiBr6/Cu2O/Au cell, after doing all optimization using SCAPS 